\title{
Geology of the Mid-Miocene Rooster Comb Caldera and Lake Owyhee Volcanic Field, eastern Oregon: silicic volcanism associated with Grande Ronde flood basalt
}

Thomas R. Benson* and Gail A. Mahood

Department of Geological Sciences

450 Serra Mall, Building 320

Stanford University, Stanford, CA 94305 USA

*corresponding author (trb@ stanford.edu; 609-658-3358) 


\section{ABSTRACT}

The Lake Owyhee Volcanic Field (LOVF) of eastern Oregon consists of rhyolitic caldera centers and lava fields contemporaneous with and spatially related to Mid-Miocene Columbia River flood basalt volcanism. Previous studies delineated two calderas in the southeastern part of LOVF near Owyhee Reservoir, the result of eruptions of two ignimbrites, the Tuff of Leslie Gulch and the Tuff of Spring Creek. Our new interpretation is that these two map units are differentially altered parts of a single ignimbrite produced in a major phreatomagmatic eruption at $15.8 \mathrm{Ma}$. Areas previously mapped as Tuff of Spring Creek are locations where the ignimbrite contains abundant clinoptilolite \pm mordenite, which made it susceptible to erosion. The resistant intracaldera Tuff of Leslie Gulch has an alteration assemblage of albite \pm quartz, indicative of lowtemperature hydrothermal alteration. Our new mapping of caldera lake sediments and pre- and post-caldera rhyolitic lavas and intrusions that are chemically similar to intracaldera Tuff of Leslie Gulch point to a single $\sim 20$ × $25 \mathrm{~km}$ caldera, which we name the Rooster Comb Caldera. Erosion of the resurgently uplifted southern half of the caldera created dramatic exposures of intracaldera Tuff of Leslie Gulch cut by post-caldera rhyolite dikes and intrusions that are the deeper-level equivalents of lava domes and flows that erupted into the caldera lake preserved in exposures to the northeast.

The Rooster Comb Caldera has features in common with more southerly Mid-Miocene calderas of the McDermitt Volcanic Field and High Rock Caldera Complex, including formation in a basinal setting shortly after flood basalt eruptions ceased in the region, and forming on eruption of peralkaline ignimbrite. The volcanism at Rooster Comb Caldera postdates the main activity at McDermitt and High Rock, but, like it, begins 300 ky after flood basalt volcanism begins in the area, and while flood basalts don't erupt through the silicic focus, are contemporaneous with the latest stages of eruptions nearby. High Rock and McDermitt rhyolites are associated with propagation of Steens Basalt dikes to the south, and LOVF rhyolites with later propagation of Grande Ronde Basalt dikes to the north and north-northwest.

Keywords: Lake Owyhee Volcanic Field, zeolites, flood basalts, Columbia River Basalt Group, rhyolitic caldera, Sucker Creek Formation 


\section{Introduction}

Continental flood basalt provinces are the products of extraordinary magmatic events in which volumes of basaltic magma enormous enough to alter the composition and temperature of Earth's atmosphere and oceans erupt over timespans as short as $10^{5}-10^{6}$ m.y. (e.g., Courtillot and Renne, 2003; Bryan and Ernst, 2008). Associated with the basaltic lavas are significant volumes of rhyolitic magma formed on interaction of the flood basalts with the continental crust and erupted as ignimbrites and lavas (e.g., Bryan et al., 2010; Pankhurst et al., 2011). This is the case in the best-exposed continental flood basalt province on Earth, the Mid-Miocene Columbia River Basalt Group of the northwestern United States (e.g., Camp et al., 2013). Although $98 \%$ of the volume of magma that erupted in Washington, Oregon, and Nevada from 16.9 to 15.0 Ma was mafic (Riedel et al., 2013), locally rhyolitic volcanism far exceeded the volume of basalt erupted (e.g., Rytuba and McKee, 1984; Cummings et al., 2000; Shervais and Hanan, 2008; Coble and Mahood, 2012). As such, it is the locale in which the "footprint" of temporally and spatially associated silicic magmatism can help differentiate between various geodynamic models for the origin and aftermath of flood basalt magmatism.

Although McDermitt Caldera (Rytuba and McKee, 1984) on the Oregon-Nevada border (Fig. 1) has tended to be the Mid-Miocene silicic center most discussed in the context of mantle plume models for the Steens/Columbia River flood basalt province and the eastward-younging silicic volcanism of the Snake River Plain (e.g., Pierce and Morgan, 1992; Perkins and Nash, 2002; Hooper et al., 2007; Leeman et al., 2008), Mid-Miocene silicic volcanism is widespread (e.g., Christiansen and Yeats, 1992; Pierce and Morgan, 1992; Brueseke et al., 2008; Shervais and Hanan 2008; Coble and Mahood, 2012; Camp et al., 2013; Streck et al., 2015). About 4,000 km³ of rhyolitic magma erupted over a wide region between 16.5 and $15.0 \mathrm{Ma}$, contemporaneous with the main phase of Steens and Columbia River Basalt activity (Coble and Mahood, 2012). The bulk

of silicic activity occurred within three major caldera complexes: McDermitt Volcanic Field, High Rock Caldera Complex, and Lake Owyhee Volcanic Field (Fig. 1).

\subsection{This study}

Lake Owyhee Volcanic Field (LOVF) was defined by Rytuba et al. (1991) as consisting of six regionally extensive ignimbrites and associated calderas as well as smaller lava dome centers and minor basalt spreading across $\sim 20,000 \mathrm{~km}^{2}$ from the Idaho border into eastern Oregon (Fig. 
1). Most of the present paper is devoted to the results of our study in the southeastern part of the LOVF, where previous workers mapped two Mid-Miocene calderas (Fig. 2), the Three Fingers Caldera and Mahogany Mountain Caldera, near Lake Owyhee in easternmost Oregon (Rytuba et al., 1991). Based on a new reconnaissance map produced during ten weeks of fieldwork during 2012-2014, augmented by geochronology and analytical work, we argue that there is a single, 20 x $25 \mathrm{~km}$ caldera that formed at $\sim 15.8 \mathrm{Ma}$ upon eruption of a single ignimbrite, the Tuff of Leslie Gulch (Fig. 2). We name this single caldera the Rooster Comb Caldera for Rooster Comb, a ridge of intracaldera ignimbrite held up by a post-caldera rhyolite intrusion (Fig. 3), and the name of the 1:24,000 USGS topographic quadrangle that contains it and much of Leslie Gulch where the best exposures of intracaldera ignimbrite occur. We interpret field relations, $x$-ray diffraction, and minor- and trace-element analyses as indicating that outcrops previously mapped as Tuff of Spring Creek are locations where Tuff of Leslie Gulch was altered at low temperatures to form zeolites. Our new mapping and ${ }^{40} \mathrm{Ar} /{ }^{39} \mathrm{Ar}$ ages, along with a consideration of the phenocryst assemblages and trace-element compositions of units lead us to reinterpret some additional stratigraphic relationships involving lavas associated with the caldera. Correlating lava outcrops and distinguishing between pre- and post-caldera lavas and intrusions allows us to propose the locations of the margins of the Rooster Comb Caldera.

This study is part of a larger effort to genetically link the timing, volume, and distribution of rhyolitic volcanism to models for the origin of flood basalts. As such, in this paper we refine the assignment of eruptive centers to the Lake Owyhee Volcanic Field based on available stratigraphic and geochronologic data and our own reconnaissance geologic work, limiting it to Mid-Miocene centers, thereby making the temporal and spatial link to the Grande Ronde Basalt Formation of the Columbia River Basalt Group more explicit. By comparing the LOVF with similar silicic volcanism at the High Rock Caldera Complex and McDermitt Volcanic Field, we provide a more accurate understanding of the timing and extent of silicic magmatism closely associated with flood basalt eruptions and the inception of the Snake River Plain/Yellowstone caldera trend.

\section{Evidence that Tuff of Leslie Gulch and the Tuff of Spring Creek are differentially altered portions of the same ignimbrite}

In their pioneering work on the volcanic geology and mineral deposits of the area around Lake Owyhee, J. Rytuba, D. Vander Meulen, M. Ferns, and coworkers at the U.S. Geological 
Survey and Oregon Department of Geology and Mineral Industries sited two calderas (Fig. 2): (1) Mahogany Mountain Caldera, named for the edifice of rhyolite lavas at its southern margin (Fig. 3), and attributed to eruption of the Tuff of Leslie Gulch and (2) Three Fingers Caldera, named for a prominent knob formed by an intracaldera rhyolite intrusion (Three Fingers Rock in Fig. 3), and thought to have formed on eruption of the Tuff of Spring Creek shortly afterward (Rytuba et al. 1985; Rytuba et al., 1989; Vander Meulen, 1989; Rytuba et al., 1991; Rytuba and Vander Meulen, 1991). They concluded that following resurgent uplift and the emplacement of rhyolite dikes within the Mahogany Mountain Caldera, the Tuff of Spring Creek erupted from the Three Fingers Caldera to the north, and ponded within the moat of the Mahogany Mountain Caldera. In addition to the two calderas, they delineated a separate center at the Honeycombs (Fig. 3), which they interpreted as consisting of coalescing rhyolitic tuff cones.

As defined by Rytuba, Vander Meulen, Ferns, and coworkers (Rytuba et al., 1985; Vander Meulen et al., 1987a,b,d; Vander Meulen et al., 1989a; Vander Meulen, 1989) the peralkaline Tuff of Leslie Gulch consists of three facies: (1) a nonwelded to welded, pale-yellow to grayish-yellow intracaldera ignimbrite with 5-13\% phenocrysts of alkali feldspar and minor quartz, forming the impressive spires in Leslie Gulch within the Mahogany Mountain Caldera, (2) a crystal-poor ashfall tuff preserved within the caldera, and (3) welded grayish-yellow to greenish-brown outflow sheets. They define the Tuff of Spring Creek as a series of greenish-yellow to light-green ash-flow tuffs with $7-12 \%$ phenocrysts of sanidine (5\%), plagioclase (1-5\%), quartz (1-2\%) and mafic phases $(<1 \%)$. They describe the Tuff of Spring Creek as having a crystal-rich base $(20-25 \%$ quartz and feldspar), and, locally within the Three Fingers Caldera, an upper "basaltic bomb member" characterized by abundant basaltic bombs $2-40 \mathrm{~cm}$ in diameter.

Our studies have led us to new interpretations of the areas previously mapped as the Tuff of Spring Creek by Vander Meulen et al. (1987a,d; 1989b): (1) The areas mapped as the "basaltic bomb member" of the Tuff of Spring Creek are extensively perlitized and columnar-jointed margins of postcaldera rhyolitic lavas and cryptodomes in contact with fine-grained, ashy caldera lake sediments, where the rhyolite contains microcrystalline, dark-colored intermediate-to-mafic enclaves up to $5 \mathrm{~cm}$ in diameter (the "basaltic bombs"). (2) Similarly, we interpret the “intracaldera member” of the Tuff of Spring Creek (Ttsi of Vander Meulen et al., 1989b) as postcaldera rhyolitic lava that interacted with caldera lake sediments, based on the absence of pumice lapilli, its stratigraphic position above the Tuff of Leslie Gulch, and sedimentary rock we 
interpret as caldera lake sediments that are entrained at its base. (3) Areas mapped as the strongly porphyritic base of the Tuff of Spring Creek are altered outcrops of postcaldera rhyolitic intrusions. Many of these intrusions contain abundant, large sodic sanidines, whereas where we have studied the intracaldera ignimbrite it is invariably phenocryst-poor with small crystals. (4) Most significantly, we conclude that ignimbrite mapped as Tuff of Spring Creek is not a separate unit; it is Tuff of Leslie Gulch that has undergone zeolitic alteration.

\subsection{Physical characteristics and stratigraphic relationships}

In areas previously mapped as Tuff of Leslie Gulch, the ignimbrite typically forms large brown to tan to orange spires and cliffs with prominent honeycomb weathering in Leslie Gulch and the eponymous Honeycombs (Figs. 4 and 5). The parts of the cliffs exposed in Leslie Gulch that have previously been mapped as the Tuff of Spring Creek weather more easily and are yellow to green in color. Although different in color, other megascopic characteristics of outcrops previously mapped as the two tuffs are indistinguishable. Both consist of intracaldera ignimbrite with $\sim 5$ vol.\% phenocrysts of sodic sanidine and rare quartz and oxidized mafic minerals. Lithics range from absent to $\sim 5$ vol. $\%$ of both facies, and consist of rhyolite lava clasts on average $1 \mathrm{~cm}$ in diameter (up to $5 \mathrm{~cm}$ ) that are in some cases perlitized or calcified. Lithic abundance increases upsection in the tuff exposed at the Honeycombs, but there is no systematic difference in lithic content between what was mapped as Tuff of Spring Creek and Tuff of Leslie Gulch.

Re-evaluation of the contacts between what has previously been mapped as the Tuff of Spring Creek and the Tuff of Leslie Gulch shows that most contacts are gradational (see also Ferns (1997)), with the green, incompetent Tuff of Spring Creek gradually transitioning to a more coherent, less-green ignimbrite initially mapped as intracaldera Tuff of Leslie Gulch. As illustrated in Fig. 5a, in Leslie Gulch, the mapped Tuff of Spring Creek is stratigraphically below what has been mapped as Tuff of Leslie Gulch, a relationship inconsistent with the previous interpretation that the Tuff of Spring Creek is younger. Where sharp, the contacts are irregular and in some localities repeat within a vertical section (Fig. 5b). These relationships suggest that the differences

in megascopic appearance are a result of different styles of post-depositional alteration of the same intracaldera ignimbrite, rather than due to there being two eruptive units.

\subsection{Contrasting alteration assemblages produce different colors and susceptibility to erosion}


Areas previously mapped as Tuff of Spring Creek and Tuff of Leslie Gulch contain different alteration assemblages. X-ray diffraction analyses of seven samples of ignimbrite previously mapped as Tuff of Leslie Gulch demonstrate that it is characterized by primary sanidine phenocrysts plus an alteration assemblage of albite \pm quartz \pm minor phyllosilicate (TB421A in Fig. 6). In contrast, seven samples collected from what had been mapped as the Tuff of Spring Creek all contain clinoptilolite \pm mordenite \pm minor smectite (TB-419A in Fig. 6). Although sodic sanidine phenocrysts are visible in both hand sample and SEM imagery (Fig. 7), its X-ray diffraction signal is not detectible due to its low abundance relative to clinoptilolite. SEM imagery of the Tuff of Spring Creek at its type locality shows that clinoptilolite replaces glass in ash shards and also forms euhedral blades in pore spaces of the ignimbrite (Fig. 7). X-ray diffraction analyses of two samples of ignimbrite in zones transitional between what was mapped as Tuff of Leslie Gulch and Tuff of Spring Creek (TB-420 in Fig. 5a) yield primary sanidine and the zeolites heulandite and analcime in addition to minor mordenite (TB-420 in Fig. 6).

We suggest that the green color of the parts of the ignimbrite previously mapped as Spring Creek Tuff is due to the abundance of Fe-bearing clinoptilolite. The extensive zeolitization of these areas also made them less resistant to erosion than adjacent areas of the ignimbrite mapped as Tuff of Leslie Gulch in which the alteration assemblage is dominated by albite and quartz.

\subsection{Overlap in trace- and minor-element compositions}

The scarcity of preserved outflow sheets and the pervasive alteration of intracaldera ignimbrite place limits on the interpretations of whole-rock chemistry of the tuff. Analyses of intracaldera samples affected by clinoptilolite \pm mordenite alteration (TB-161, TB-179, TB-304A; Table 1) show high loss on ignition ( 4-11\%) and low concentrations of easily mobilized alkali elements. Outflow Tuff of Leslie Gulch provides a closer approximation to magmatic compositions, because it has not been subject to intracaldera alteration. It is an alkali rhyolite with an agpaitic index $\left.\left(\mathrm{mol} . \mathrm{Na}_{2} \mathrm{O}+\mathrm{K}_{2} \mathrm{O}\right) / \mathrm{Al}_{2} \mathrm{O}_{3}\right)$ of 0.98 (e.g., TB-109 in Table 1), making it metaluminous by strict definition. However, because alkalies are commonly lost on devitrification or secular hydration (MacDonald and Bailey, 1973), and the measured Zr concentrations ( 725$825 \mathrm{ppm}$ ) are similar to other less-altered peralkaline ignimbrites in the region (Fig. 8), we consider the Tuff of Leslie Gulch to be weakly peralkaline, consistent with the designations by previous workers (Vander Meulen, 1989; Rytuba and Vander Meulen, 1991). The presence of a 
single feldspar, sodic sanidine, as a phenocryst is also consistent with the tuff being weakly peralkaline.

The analyses for the intracaldera Tuff of Leslie Gulch show more scatter than the data for the outflow sheet, as would be expected given its greater alteration. On the bivariate chemical plots of $\mathrm{Nb}, \mathrm{Zr}, \mathrm{Ba}, \mathrm{TiO}_{2}$, and $\mathrm{FeO} *$ in Fig. 8, samples of the intracaldera ignimbrite are generally shifted to lower values of both incompatible and compatible elements compared to the outflow sheet, suggesting that the range reflects, at least in part, dilution by silicification and precipitation of zeolites.

The compositions of samples of ignimbrite mapped as intracaldera Tuff of Spring Creek and intracaldera Tuff of Leslie Gulch overlap on bivariate plots of minor and trace elements, and are distinct from trends for other ignimbrites in LOVF and the northern Basin and Range (Fig. $8^{1}$ ), strong evidence they are the same unit.

\subsection{Identical ${ }^{40} \mathrm{Ar} /{ }^{39} \mathrm{Ar}$ ages within analytical uncertainties}

New ${ }^{40} \mathrm{Ar} /{ }^{39} \mathrm{Ar}$ ages for sodic sanidine phenocrysts from intracaldera and outflow samples from what has been mapped as the Tuff of Spring Creek and Tuff of Leslie Gulch are consistent with them being the same ignimbrite. Outflow Tuff of Leslie Gulch yielded a precise age of 15.84 $\pm 0.05\left(2 \sigma^{2}\right)$ Ma (TB-109 in Table 2 and Appendix B). A sample of intracaldera ignimbrite mapped as Tuff of Spring Creek (TB-161 in Fig. 3) yielded two indistinguishable ages of $15.75 \pm$ $0.05 \mathrm{Ma}$ and $15.83 \pm 0.03 \mathrm{Ma}$ on splits analyzed in separate irradiations. Samples of ignimbrite mapped as Tuff of Spring Creek near the southern caldera margin (TB-304A), and ignimbrite transitional in appearance between the two types (TB-179) yielded low-precision ages of $15.87 \pm$ $0.37 \mathrm{Ma}$ and $15.83 \pm 0.27 \mathrm{Ma}$, respectively, that nevertheless unresolvable from the more precise ages. Combining all the new ages yields a weighted mean age of $15.81 \pm 0.05 \mathrm{Ma}$ (Fig. 9) for the Tuff of Leslie Gulch.

\section{Geologic history of the Rooster Comb Caldera}

\footnotetext{
${ }^{1}$ XRF analytical data appear in on-line Supplementary Material Appendix A.

${ }^{2}$ All errors are reported as $2 \sigma$. We report inverse isochron ages to weighted mean ages because samples yielded $30-$ $90 \%$ radiogenic argon concentrations. Complete ${ }^{40} \mathrm{Ar} /{ }^{39} \mathrm{Ar}$ analytical data appear in on-line Supplementary Material Appendix B.
} 
Based on the foregoing evidence we conclude that what was previously mapped as the Tuff of Spring Creek and the Tuff of Leslie Gulch are parts of a single eruptive unit that underwent different styles of secondary alteration. We have adopted the name Tuff of Leslie Gulch for the singular ignimbrite, as it is more voluminous than what has been mapped as Tuff of Spring Creek, and has been more extensively studied (e.g., Vander Meulen, 1989). Outcrops of the Tuff of Leslie Gulch are also more accessible and memorable than their zeolitized counterparts.

In this section we present the geologic setting and eruptive history of the caldera we propose formed on eruption of the Tuff of Leslie Gulch, the Rooster Comb Caldera, by describing in sequence Mid-Miocene units in and around the caldera.

\subsection{Precaldera stratigraphy}

\subsubsection{Birch Creek low-silica rhyolite lavas}

The first rhyolitic unit to erupt in the region that is known to be Mid-Miocene in age is the Birch Creek low-silica rhyolite lavas, which occur south of the Rooster Comb Caldera (Fig. 3). This unit is typified by 150-m-high exposures of flow-banded, devitrified, tan lava in cliffs near the Birch Creek campground (Fig. 2), and it forms several exogenous lava domes northeast of Birch Creek. With 12-20\% phenocrysts of plagioclase, hornblende, biotite, and minor alkali feldspar, this metaluminous lava is easily distinguished from all the other Mid-Miocene rhyolitic lavas in southern LOVF. Locally, along the Birch Creek Road, a facies of the lava is variably hydrated with blue to gray cores of weakly hydrated material surrounded by yellow pervasively hydrated and altered hydrated material. Plumley (1986) mapped exposures along the Birch Creek Road as Birch Creek Tuff, but we have found no fiamme or lithics to indicate a pyroclastic origin of the main body of the unit. There are, however, minor pyroclastic flows with similar phenocryst assemblage exposed and locally fused along the margins of the main lava body, primarily along Birch Creek and northeast of the campground near the Owyhee River.

Our new ${ }^{40} \mathrm{Ar} /{ }^{39} \mathrm{Ar}$ age of $16.8 \pm 1.1 \mathrm{Ma}$ on plagioclase from the Birch Creek low-silica rhyolite lava (sample TB-278A in Table 2) is of such low precision that it does not establish conclusively that this unit is older than the 15.81 Ma Tuff of Leslie Gulch. Plumley (1986), Vander Meulen et al. (1990), and Ferns et al. (1993b) interpreted it as younger than the Leslie 
Gulch Tuff ${ }^{3}$. We have not found it in direct stratigraphic relation with the Tuff of Leslie Gulch. We assign it this stratigraphic position because we have mapped it as being truncated by collapse of the Rooster Comb Caldera (Fig. 3).

Our new minor- and trace-element analyses of the Birch Creek low-silica rhyolite domes, including samples from localities mapped as Birch Creek Tuff by Plumley (1986), show them to have significantly lower $\mathrm{Zr}$ and $\mathrm{Nb}$ concentrations than the Tuff of Leslie Gulch and lavas unambiguously associated with the Rooster Comb caldera (Fig. 10). Nash and Perkins (2012) note that biotite and hornblende are essentially absent in regional-scale rhyolitic ash falls erupted from centers associated with the Yellowstone/Snake River Plain trend, consistent with our interpretation that the Birch Creek rhyolite predates and is only peripherally related to LOVF volcanism. At High Rock Caldera Complex and McDermitt Volcanic Field, small volumes of metaluminous lavas erupted both before and after the voluminous peralkaline caldera-forming rhyolites (Henry et al., 2006; Starkel, 2014; Coble and Mahood, in press). These volumetrically minor metaluminous silicic rocks are interpreted by Coble and Mahood (in press) as reflecting the waxing and waning stages of short but intense episodes of crustal magmatism associated with intrusion of flood basalt dikes. The Birch Creek low-silicic rhyolite may stand in similar relationship to the main phase of peralkaline volcanism at Rooster Comb Caldera.

\subsubsection{Sucker Creek Formation}

Exposed north and east of the Rooster Comb Caldera are the Mid-Miocene tuffaceous sediments of the >600-m-thick Sucker Creek Formation (Lawrence, 1988; Downing, 1992), which overlies basalts correlative with Columbia River flood basalts (Kittleman et al., 1965; Lawrence, 1988; Ferns et al., 1993b). The formation consists of a lower part dominated by diatomite, claystone, and well-stratified tuffaceous and volcaniclastic sediments that were deposited in a lacustrine or lakeshore environment, overlain by a subaerially deposited upper part consisting of pumice-bearing fluvial, overbank, and paleosol deposits famous for their Barstovian land mammal fossils (Kittleman et al., 1965; Cross and Taggart, 1982; Lawrence, 1988; Downing, 1992).

\footnotetext{
${ }^{3}$ Plumley (1986) and Vander Meulen et al. (1990) concluded that the Birch Creek Tuff is younger than the Leslie Gulch Tuff based on outcrops where it overlies with angular unconformity pyroclastic deposits near the Birch Creek campground (Figs. 2 and 3). They identified these deposits as the Tuff of Leslie Gulch, whereas we interpret them as tilted, tuffaceous, basinal sediments that predated the Tuff of Leslie Gulch.
} 
Kittleman et al. (1965) included the Tuff of Leslie Gulch within the Sucker Creek Formation, placing it near the top of the section.

Where it outcrops immediately north and northeast of the Rooster Comb Caldera, the Sucker Creek Formation grades from brownish-tan sediments with a large component of intermediate to mafic phreatomagmatic debris to a thick sequence of green to white tuffaceous sediments and claystones with input from more evolved volcanic products. These sediments were previously mapped in Sage Creek (Fig. 3) as the Tuff of Spring Creek (Vander Meulen et al., 1989b), where the section contains greenish-yellow to white tuffaceous sediments consisting of thick to very thick, massive-bedded, fine-grained sandstones and thin to medium, planar-bedded conglomerates containing rounded to sub-rounded pebbles of rhyolite and intermediate lavas. The rounding of the lithic clasts and quartz and feldspar grains in the massive beds suggests that this material was not primary, but reworked volcaniclastic debris. The nature of the sediments and the presence of phreatomagmatic debris lower in the section suggest a lakeshore depositional environment.

Where exposed along Succor Creek near its confluence with Sage Creek (Fig. 3), the lacustrine lower part of the Sucker Creek Formation was eroded to form a paleovalley that was subsequently filled by outflow Tuff of Leslie Gulch. The contact between the ignimbrite and the sediments is irregular and locally very steep, about $80^{\circ}$ (Fig. 11). This unconformable relationship indicates that the onset of Sucker Creek Formation sedimentation occurred prior to eruption of the Tuff of Leslie Gulch and collapse of the Rooster Comb Caldera.

Ages of ashes intercalated with the lower and upper part of the Sucker Creek Formation indicate that sedimentation continued afterward as well. Downing and Swisher (1993) report three ${ }^{40} \mathrm{Ar} /{ }^{39} \mathrm{Ar}$ ages ${ }^{4}$ for ashes interbedded with the Sucker Creek Formation near Devil's Gate $(\sim 7 \mathrm{~km}$ north of the Succor Creek campground on Fig. 2): 15.6 for an ash layer within the upper part of the lacustrine (lower) section of the Sucker Creek Formation, and ages of 15.2 Ma and 15.0 Ma for ashes in the lower part and upper part, respectively, of the overlying vertebrate-bearing fluvial and subaerial section. At the type locality, $\sim 2 \mathrm{~km}$ southeast of the Succor Creek Campground (Fig. 2), an ash above the vertebrate-bearing horizon and midway through the type section, yielded an age

\footnotetext{
${ }^{4}$ All ages recalculated to an age of 28.02 Ma for the Fish Canyon sanidine (Renne et al., 1998).
} 
of 14.9 Ma. These four ages ranging from 15.6 to 14.9 Ma indicate that sedimentation continued at least locally after eruption of the Tuff of Leslie Gulch for ca. 1 my.

\subsubsection{Intermediate lavas intercalated within the Sucker Creek Formation}

Deposition of the Sucker Creek Formation near what was to become the Rooster Comb Caldera was accompanied by mafic to intermediate volcanism, the products of which are observed mostly along the north and northeast margins of the caldera; elsewhere, extensive cover by younger volcanic and sedimentary deposits precludes an estimation of its extent. In lower Sage Creek, a trachytic lava with $~ 10-15 \%$ feldspar phenocrysts and a dense, black to mahoganycolored aphanitic matrix occurs within the sediments of the Sucker Creek Formation. In most places the lava is flow-banded with an autobrecciated base, but locally it is invasive into the sediments, suggesting it erupted in a littoral setting. A cliff west of Succor Creek (4 km north of the campground in Fig. 2 and illustrated in Fig. 11) exposes an intermediate lava with 5\% feldspar phenocrysts and an aphanitic matrix interbedded with the sediments of the Sucker Creek Formation. The upper part of this sedimentary section is crosscut by a columnar-jointed trachyte dike with $\sim 10 \%$ phenocrysts of blocky feldspar that feeds an overlying 2- to 3-m-thick lava with an autobrecciated base. At this location, the McIntyre Ridge rhyolite lava conformably overlies the trachyte, and caps the exposed section of the lower lacustrine part of the Sucker Creek Formation.

Given their stratigraphic position within the lower part of the Sucker Creek Formation, these intermediate lavas postdate basalts correlated with Columbia River flood lavas, and predate major rhyolitic volcanism in the region, including eruption of the Tuff of Leslie Gulch. They stand in the same stratigraphic position as intermediate lavas mapped between Steens Basalt flood lavas and the peralkaline ignimbrites of the McDermitt Volcanic Field (Starkel, 2014; Benson and Mahood, 2015), suggesting that they are evidence of a similar magmatic transition from flood basalts to rhyolites at Rooster Comb Caldera.

\subsubsection{McIntyre Ridge rhyolite lava}

The earliest silicic lavas we unambiguously associate with the Rooster Comb Caldera magmatic system form the McIntyre Ridge rhyolite composite lava dome. It consists of porphyritic high-silica rhyolite lavas with two distinct phenocryst assemblages: (1) most are strongly porphyritic, with 20 vol.\% large (up to $1 \mathrm{~cm}$ ) alkali feldspars and 10 vol.\% resorbed 
quartz grains that are more numerous but much smaller in size (up to $2 \mathrm{~mm}$ ); and (2) slightly less porphyritic lavas with $\sim 10$ vol. $\%$ alkali feldspar up to $7 \mathrm{~mm}$ in length and $\sim 10 \%$ smoky, round quartz $\sim 2 \mathrm{~mm}$ in diameter. Both lava types have trace Fe-Ti oxides, pyroxenes, and zircons that commonly occur in small clots no larger than a few millimeters. The McIntyre lavas share with the Tuff of Leslie Gulch the elevated concentration of $\mathrm{FeO}^{*}$ and a phenocryst assemblage characteristic of reduced, relatively dry rhyolites - a single feldspar and the presence of pyroxene as opposed to biotite and hornblende (Christiansen and McCurry, 2008) - though they are more evolved (lower $\mathrm{TiO}_{2}$ and $\mathrm{FeO} *$ ). Additionally, the lower $\mathrm{Zr}, \mathrm{Nb}$, and $\mathrm{REE}$ concentrations suggest that they are metaluminous (Fig. 10) rather than weakly peralkaline.

We estimate the maximum thickness of the lavas to be $\sim 500 \mathrm{~m}$ along the southern half of McIntyre Ridge (Fig. 3); they thin northward and eastward to about $15 \mathrm{~m}$ where the base of a lava overlying the intermediate lavas and tuffaceous sediments of the Sucker Creek Formation is exposed. The base of the McIntyre Ridge rhyolite composite dome is characterized in nearly all localities by an anomalously thick vitric zone, which suggests the lavas erupted into water or onto wet sediments. The vitric base typically has lithophysae, which are locally abundant and as large as $50 \mathrm{~cm}$ in diameter. Where filled with agate (Fig. 12), the lithophysae are referred to as "thundereggs," the state rock of Oregon, and are commonly collected by rockhounds. The abundance of lithophysae decreases upsection as a result of the sustained elevated temperatures in the interior of the lavas that result in complete devitrification of matrix glass.

The abrupt termination of the McIntyre Ridge composite dome along the western edge of McIntyre Ridge suggests that the dome was truncated by collapse of the Rooster Comb Caldera. One rhyolite lava lithic fragment (symbol with an L in Fig. 10) collected in the intracaldera Tuff of Leslie Gulch has trace element concentrations that match the McIntyre Ridge rhyolite, further demonstrating that this unit is precaldera in age. On the west side of Succor Creek, a McIntyre Ridge lava flow conformably overlies lacustrine sediments and intercalated intermediate lavas of the lower part of the Sucker Creek Formation. Scraps of outflow Tuff of Leslie Gulch are preserved in Succor Creek in a paleovalley cut in these weakly consolidated deposits where they were not protected by overlying McIntyre Ridge lava (Fig. 11). 
Our new ${ }^{40} \mathrm{Ar} /{ }^{39} \mathrm{Ar}$ age of $15.91 \pm 0.27 \mathrm{Ma}(\mathrm{TB}-112$ in Table 2) on sanidine from McIntyre Ridge rhyolite is consistent with a K-Ar age of $15.8 \pm 0.6 \mathrm{Ma}$ on the unit ${ }^{5}$ measured by Ekren et al. (1984), and is unresolvable from our age of 15.81 Ma for the Tuff of Leslie Gulch (Fig. 9). This suggests it is closely linked to the Rooster Comb magmatic system and erupted within tens to hundreds of thousands of years prior to the caldera-forming eruption.

\subsection{Eruption of the Tuff of Leslie Gulch and Collapse of the Rooster Comb Caldera}

The Tuff of Leslie Gulch erupted at 15.81 Ma, and we suggest resulted in collapse of a single $\sim 20$ x 25 caldera we have named the Rooster Comb Caldera.

\subsubsection{Tuff of Leslie Gulch}

The Tuff of Leslie Gulch is a sparsely porphyritic, weakly peralkaline, alkali rhyolite containing phenocrysts of sodic sanidine and sparse quartz and oxidezed mafic phases. Lithics abundances are $0-5 \%$ and consist dominantly of rhyolite and mafic lava with minor sandstone. The ranges exhibited by less easily mobilized elements $\mathrm{TiO}_{2}(\sim 0.20-0.35 \mathrm{wt} \%)$ and $\mathrm{FeO}(\sim 1.3-3.4$ wt $\%$ ) suggest that the Tuff of Leslie Gulch is weakly compositionally zoned.

There are very limited exposures of outflow ignimbrite because many areas around the caldera are covered by younger volcanic rocks and sediments; in addition, as discussed in 5.3, much of the outflow may have been nonwelded, so was largely stripped by erosion. Where outflow occurs northeast and south of the caldera, it forms 5- to 10-m-thick, incipiently to densely welded benches atop basalts and Sucker Creek Formation (Fig. 11). We were able to sample different levels in the outflow sheet in Succor Creek (Fig. 11), where it is $\sim 10 \mathrm{~m}$ thick and contains two welding reversals. The base is slightly more evolved than the rest of the tuff: upsection, $\mathrm{FeO}^{*}$ increases from 3.0 to $3.4 \mathrm{wt} \%$, and $\mathrm{Ba}$ increases from 1500 to $1900 \mathrm{ppm}$. Incompatible elements $\mathrm{Zr}$ and $\mathrm{Nb}$ decrease upward over the same interval (770 to $720 \mathrm{ppm}$ and 54 to $46 \mathrm{ppm}$, respectively). In densely welded outflow ignimbrite, the phenocryst content is $\sim 10$ vol. $\%$.

\footnotetext{
5 This age from Ekren et al. (1984) was published as the Tuff of Leslie Gulch, but revisiting their coordinates revealed that they dated sanidine from the McIntyre Ridge rhyolite lava and not the ignimbrite.
} 
In the main exposures of the Tuff of Leslie Gulch, where it exceeds $700 \mathrm{~m}$ thickness and we have interpreted it as an intracaldera facies, post-eruptive hydrothermal and diagenetic alteration have severely masked primary pyroclastic features, making it difficult to characterize the original deposit. Pumice lapilli are conspicuously rare, and vitriclastic and eutaxitic textures are absent, so it is difficult to establish whether the intracaldera section was welded or not. Locally, one can identify intercalated fall deposits a few centimeters thick and low-angle, crossbedded surge deposits, as well as crude stratification in the ignimbrite, indicating that at least part of the section was nonwelded. Spherical features 3-5 $\mathrm{mm}$ in diameter in massive tuff appear to be altered accretionary lapilli, but we cannot exclude the possibility that they were spherulites in now-altered densely welded vitrophyre. The intracaldera ignimbrite contains $\sim 5$ vol. $\%$ phenocrysts of sodic sanidine.

Given the difficulty determining the welding status of the ignimbrite and the relative scarcity of lithics and the absence of lithic megabreccias, we considered the possibility that the Tuff of Leslie Gulch in Leslie Gulch is, despite the great exposed thickness, not intracaldera; rather, that it was sourced elsewhere and flowed into a topographically low area that is now occupied by Leslie Gulch and the Honeycombs. We concluded that this is unlikely because, with the exception of the McIntyre Ridge rhyolite lavas, which are clearly truncated by caldera collapse, the landscape prior to eruption of the Tuff of Leslie Gulch appears to have not been one of great relief, as the surface consisted largely of the sediments of the Sucker Creek Formation. The lack of resistant lithologies makes it hard to imagine how more than $700 \mathrm{~m}$ of relief could have been present. Moreover, several lines of evidence point to the Tuff of Leslie Gulch being sourced at the Rooster Comb Caldera rather than having flowed into the area from elsewhere: (1) the unresolvable ${ }^{40} \mathrm{Ar} /{ }^{39} \mathrm{Ar}$ ages for the Tuff of Leslie Gulch and some of the intracaldera intrusions (Fig. 9), (2) the chemical similarity of the intrusions and the tuff they intrude (Fig. 10), and (3) the lesser amount of zeolitization and hydrothermal alteration in what are interpreted as outflow exposures of the ignimbrite compared those within the caldera, suggesting that elevated temperatures and a relatively closed hydrologic system within the caldera promoted extensive alteration.

\subsubsection{Honeycombs}


Iginimbrite exposed at the Honeycombs (Fig. 3) was assigned to a separate volcanic center by Vander Meulen et al. (1987c), Rytuba and Vander Meulen (1991), and Cummings et al. (2000). Our limited reconnaissance mapping in this difficult-to-access area and examination of satellite imagery did not provide any reason to separate the Honeycombs from megascopically similar areas of intracaldera Tuff of Leslie Gulch; hence, it appears as such on our geologic map in Fig. 3.

Samples of ignimbrite that we collected from the lower two thirds of the Honeycombs section exposed along the shore of Lake Owyhee are significantly more evolved than samples of Tuff of Leslie Gulch, but they lie on extensions to more evolved compositions of the trends in the outflow Tuff of Leslie Gulch (Fig. 8). The ignimbrite at the Honeycombs is similar in composition to some of the postcaldera, intracaldera rhyolite dikes and intrusions (Fig. 10). These chemical similarities argue against the Honeycombs being an unrelated volcanic center. As such, we interpret the Honeycombs as representing the first-erupted portion of the Tuff of Leslie Gulch, which erupted from the uppermost, most evolved portion of the magma chamber, remnants of which were tapped again as postcaldera intrusions. Although we tentatively include the Honeycombs within the Rooster Comb Caldera as intracaldera Leslie Gulch Tuff, it is also possible that it represents the deposits of phreatomagmatic eruptions associated with emplacement of postcaldera rhyolitic lavas, given their chemical similarity (Fig. 10). Detailed mapping and additional chemical analyses of the tuff at the Honeycombs will be required to fully characterize its relationship to the Rooster Comb magmatic system.

\subsubsection{Collapse of the Rooster Comb Caldera}

The great thickness of Tuff of Leslie Gulch exposed in the eponymous canyon, $700 \mathrm{~m}$ with the base unexposed, is one of the main reasons to conclude that caldera collapse accompanied eruption of the tuff. The truncation of McIntyre Ridge rhyolite lavas and the incorporation of a lithic block within the ignimbrite that is the same composition as the McIntyre Ridge rhyolite lava, and the eruption of the postcaldera Three Finger Rock lava (see 3.3.2) within a time frame unresolvable from the 15.81 Ma age for the Tuff of Leslie Gulch is supportive evidence. Because the margin of the caldera (discussed in 4.1) is covered in many areas, we have little evidence for the nature of the collapse. We speculate that the floor of the caldera, consisting of Sucker Creek Formation, may be exposed near the confluence of Birch Creek and Lake Owyhee. This area, 
among the topographically lowest exposed within the proposed caldera is also within the focus of resurgent uplift, making it the structurally deepest area exposed.

\subsection{Post-caldera stratigraphy}

\subsubsection{Caldera lake sedimentation}

White, fine-grained, laminated, diatomaceous sediments that we interpret as being deposited in a caldera are found: (1) locally along the southern margin of the caldera above the intracaldera tuff where they are protected by overlying Mahogany Mountain rhyolite lava that flowed into the caldera lake; (2) in the central to northern part of the caldera where they are locally preserved by overlying and intercalated post-caldera rhyolite lavas; and (3) along the eastern margin of the caldera, north of and surrounding Bannock Ridge (Fig. 3).

Post-caldera volcanism within the caldera lake was contemporaneous with caldera lake sedimentation. Lavas show anomalously thick vitric zones characteristic of erupting into water, and, locally, autobrecciated glass or pumiceous margins of flows incorporate ashy sediments. Drill logs provided to the authors by ASARCO Inc. from 150-m-deep gold exploration drill holes around the Katie Prospect southwest of McIntyre Ridge (Fig. 2) document (unanalyzed) rhyolite lava that are meters to $\sim 80 \mathrm{~m}$ thick intercalated within the sedimentary section.

We interpret white, laminated, diatomaceous sediments with intercalated mafic phreatomagmatic deposits along Carter Creek as caldera lake sediments, but detailed mapping is required to definitively distinguish them from the precaldera sediments of the lacustrine interval of the lower part of the Sucker Creek Formation and from the younger sediments of the OregonIdaho Graben.

\subsubsection{Intracaldera rhyolitic lavas and intrusions}

Following eruption of the Tuff of Leslie Gulch and collapse of the Rooster Comb caldera, rhyolitic dikes, intrusions, domes, and flows were emplaced throughout the caldera and along the northeastern ring fracture (Fig. 3). In the northern part of the Rooster Comb Caldera (previously identified as the Three Fingers Caldera by Rytuba et al. (1991), post-caldera rhyolitic lavas are preserved. The lavas outcrop as rhyolite plugs (e.g., Three Fingers Rock) and lava domes (e.g., Smith Butte) (Fig. 3). Southwest of Three Fingers Rock, we find exposures where glassy autobrecciated bases of the lavas locally interacted with and entrained caldera lake sediments. The 
manifestations of this post-caldera volcanism to the south, in the area interpreted as the Mahogany Mountain Caldera by earlier workers, are dikes and minor sills that are, for the most part, chemically and petrographically equivalent to the domes exposed in the north (Fig. 10). The dikes weather in positive relief against the Tuff of Leslie Gulch, and ubiquitously display strong horizontal columnar joints (Fig. 4). Individual dikes range in width from less than a meter to 15 meters, and can be traced for as long as $8 \mathrm{~km}$ (Fig. 3). The dikes trend broadly N-S, an orientation consistent with regional E-W extension associated with subsidence of the Oregon-Idaho Graben (Cummings et al., 2000).

The post-caldera rhyolite lavas and intrusions are dominantly high-silica alkali rhyolites and, with the exception of the lava at Smith Butte, have one of two distinct phenocryst assemblages: one with $\sim 8 \%$ alkali feldspar and 0-2\% quartz, and the other with phenocrysts of $\sim 15 \%$ sanidine up to $1 \mathrm{~cm}$ in length and $\sim 5 \%$ clear resorbed quartz. The two petrographic varieties are chemically indistinguishable (within the uncertainties imposed by the fact that they are all somewhat altered), and they do not exhibit a systematic spatial distribution; hence, we group them into a single unit.

The 15.61 \pm 0.05 Ma rhyolite lava dome at Smith Butte (Fig. 3) has a phenocryst assemblage unique among Rooster Comb rhyolites, characterized by 15\% quartz ( $2 \mathrm{~mm}), 5 \%$ altered plagioclase (?) phenocrysts up to $7 \mathrm{~mm}$ in length, and $5 \%$ tabular (3 $\mathrm{mm}$ long), chatoyant sanidine. This quartz-rich lava is one of the most evolved analyzed rhyolites associated with the caldera (0.07 wt \% $\mathrm{TiO}_{2} ; \mathrm{S}$ in Fig. 10), and lies on an extension to more evolved compositions of the trends shown by the intracaldera postcaldera rhyolites in bivariate chemical plots.

The intracaldera rhyolite lavas, dikes, sills, and intrusions are chemically more evolved than the Tuff of Leslie Gulch, nearly all having $\mathrm{TiO}_{2}$ contents $<0.24 \%$. In contrast to the trends formed by the outflow tuff (and the tuff at the Honeycombs), $\mathrm{Zr}$ declines with decreasing $\mathrm{TiO}_{2}$ and $\mathrm{Ba}$, which may reflect stabilization of zircon and its fractionation in magmas that gave rise to the postcaldera intrusions (Fig. 10). A similar contrast in the Zr enrichment patterns of calderaforming ignimbrite and postcaldera lavas is found in the weakly peralkaline, high-silicic alkali rhyolite at the Pleistocene La Primavera Caldera (Mahood, 1980).

We obtained three new ${ }^{40} \mathrm{Ar} /{ }^{39} \mathrm{Ar}$ sanidine ages for the intracaldera rhyolite lavas and intrusions: $15.87 \pm 0.28 \mathrm{Ma}$ on a perlitic intrusion exposed in Leslie Gulch (TB-185 in Figs. 3 and 9), $15.72 \pm 0.06$ Ma for the Three Fingers Rock rhyolite dome (TB-196), and 15.61 \pm 0.05 Ma on 
the Smith Butte rhyolite lava dome (TB-193). Based on these ages, we conclude that intracaldera eruptive activity occurred within $~ 100-200$ ky of eruption of the Tuff of Leslie Gulch and formation of the caldera, and some of it may have immediately postdated collapse.

\subsubsection{Rattlesnake Den rhyolite lava}

We reinterpret exposures of silicic rocks southwest of Mahogany Mountain mapped as outflow facies of the Tuff of Leslie Gulch by previous workers (Plumley, 1986; Vander Meulen et al., 1990; Ferns et al., 1993b) as a rhyolitic lava dome, which we informally name Rattlesnake Den rhyolite lava (Fig. 3). We based this interpretation on the lack of lithic fragments and fiamme, and the presence of dark-colored magmatic enclaves $(<5 \mathrm{~mm}$, constituting less than $1 \mathrm{vol}$. $\%$ of the rock) and well-developed flow foliations. In addition, the phenocryst assemblage differs from the $\sim 10$ vol.\% sanidine typical of outflow exposures of the Tuff of Leslie Gulch; the lava contains approximately $15 \%$ sanidine and $10 \%$ quartz phenocrysts. Vitric portions of the lava on the western side of the Birch Creek Road, close to the contact with overlying Quaternary basalt, have been hydrated locally to a deep blue perlite.

A dike of the Rattlesnake Den rhyolite lava intrudes the Birch Creek low-silica rhyolite in upper Birch Creek, and the lava overlies the Birch Creek rhyolite in a few locations. We have found no clear stratigraphic age relations with the Tuff of Leslie Gulch, but a new age of $15.63 \pm$ $0.06 \mathrm{Ma}$ (TB-156; Table 2) on an outcrop of the unit south of the Birch Creek Road (1.5 km from the southern edge of the map in Fig. 3) is consistent with this unit erupting after the ignimbrite. Although the Rattlesnake Den rhyolite lava occurs south of the caldera, it has the same age as intracaldera rhyolite intrusions and lavas, and it falls along the same chemical trends (Fig. 10).

\subsubsection{Mahogany Mountain rhyolite lava}

The largest volume of preserved postcaldera lavas occurs along the southern margin of the caldera, where a stack of rhyolitic lavas as much as $500 \mathrm{~m}$ thick forms the edifice of Mahogany Mountain. Rytuba et al. (1991) suggested that the Mahogany Mountain lavas are precaldera in age, based on what they interpreted as a 10-km-long fault scarp along the northern margin of the mountain that formed on caldera collapse. We interpret this irregular scarp as erosional, a result of failure of rhyolite lava atop weak, unconsolidated, caldera lake sediments - analogous to a failure northeast of Blue Canyon that resulted in a large Quaternary landslide (Fig. 3) that affected the 
course of the Owyhee River (Ely et al., 2012). Near the western edge of its exposure, the autobrecciated base of a Mahogany Mountain rhyolite lava overlies caldera lake sediments, which in turn overlie the Tuff of Leslie Gulch. Additional evidence for the Tuff of Leslie Gulch being older is the presence of at least two dikes that are the compositional equivalents to the Mahogany Mountain lavas crosscutting intracaldera ignimbrite just north of Mahogany Mountain in Dago Gulch (Fig. 3). Given that the edifice parallels the southern margin of the caldera, and that lavas flowed both north into the lake and south of the caldera, we suggest that the lavas vented from along the southern ring fracture zone.

The lavas of Mahogany Mountain rhyolite comprise two compositional and petrographic groups (Fig. 10). Lavas of the upper sequence are chemically similar to the more evolved of the intracaldera lavas and intrusions and postcaldera Rattlesnake Den lavas. These lavas have 5-10 vol.\% phenocrysts of subequal amounts of sanidine and quartz. Lavas from basal exposures near Carter Creek, at Bannock Ridge, and at the base of the section exposed along the northern edge of Mahogany Mountain contain higher concentrations of $\mathrm{FeO}^{*}$ and $\mathrm{Ba}(>1500 \mathrm{ppm})$ at similar $\mathrm{TiO}_{2}$ and $\mathrm{Zr}$ concentrations, making them compositionally distinct. Lavas in this lower section have fewer phenocrysts, ranging from aphyric to 5 vol.\% sodic sanidine.

We assign rhyolite lavas that outcrop along Bannock Ridge (Fig. 3) (the Bannock Ridge rhyolite, Trb, of Vander Meulen et al. (1987a)) to the Mahogany Mountain rhyolite based on physical continuity and their similarities in phenocryst assemblages and whole-rock compositions (Fig. 10). The lowest flow at Bannock Ridge flow is almost entirely perlitic, consistent with it having flowed into a shallow lake or atop wet caldera lake sediments.

We obtained a ${ }^{40} \mathrm{Ar} /{ }^{39} \mathrm{Ar}$ sanidine age of $15.63 \pm 0.05 \mathrm{Ma}$ on a sample of the upper part of the Mahogany Mountain rhyolite lava sequence on Mahogany Mountain south of Dago Gulch (TB-305 in Fig. 3 and Appendix B). This age is resolvably younger than the 15.81 Ma age of the Tuff of Leslie Gulch, but is analytically indistinguishable from the equally precise ages of 15.63 Ma obtained for the Rattlesnake Den rhyolite lava and 15.61 Ma for the intracaldera lava dome at Smith Butte.

We speculate that the compositions of the lower Mahogany Mountain lavas reflect recharge that reset the bulk composition of magma remaining in the chamber following collapse to a slightly more mafic composition (greater FeO* and lower $\mathrm{Zr}$ in Fig. 10). The high $\mathrm{Ba}$ concentrations (>1500 ppm) despite being aphyric or containing no more than $5 \%$ phenocrysts of 
sanidine suggests that they contain a cumulate component rich in alkali feldspar or anorthoclase that was melted on interaction with hotter, more-mafic magma (Wolff et al., 2015). As such, they represent lavas that erupted along the southern ring-fracture zone shortly after caldera collapse.

\subsubsection{Resurgent uplift}

Lavas forming the upper part of Mahogany Mountain and Bannock Ridge are slightly more evolved compositions that, with 5-10\% phenocrysts of subequal amounts of sanidine and quartz, resemble the other postcaldera rhyolites (Fig. 10). We suggest that resurgent uplift focused on the south-southwestern part of the caldera ring fracture may have culminated in eruption of the Rattlesnake Den rhyolite lavas just south of the caldera, and may have caused the upper Mahogany Mountain rhyolite lavas, which also vented from the ring fracture, to flow mostly to the south. Resurgent uplift of the southwestern part of the caldera would also account for why the northeastern part of the caldera preserves caldera lake sediments and lava flows, despite being at lower elevations than the southern part of the caldera, where dikes are the dominant form of immediately post-caldera intracaldera volcanism preserved (Fig. 3).

\section{Locating the margins of the Rooster Comb Caldera and estimating the volume of the Tuff of Leslie Gulch}

\subsection{Delineating the margin of the Rooster Comb Caldera using the distribution of caldera lake} sediments and pre- and post-caldera lavas

We use new mapping, stratigraphic relationships, chemical correlations, and geochronology to delineate the Rooster Comb Caldera. Our ability to do this accurately is limited by the fact that sediments and volcanic rocks associated with the slightly younger Oregon-Idaho Graben (Cummings et al., 2000, Ferns and McClaughry, 2013) overlap the western and northern margin of the caldera, and Upper Miocene Owyhee Front rhyolites and Quaternary basalts obscure parts of the southern and eastern margin.

The northeastern topographic margin of the caldera is marked by the sharp western edge of McIntyre Ridge (solid line in Fig. 3), where the pre-caldera McIntyre Ridge rhyolite lavas were truncated by caldera collapse. The post-caldera Three Fingers Rock rhyolite lava erupted along the ring fracture in this location and banked in against the then-topographically high McIntyre Ridge rhyolite lava. Mid-to Late-Miocene normal faulting (Ferns et al., 1993a; b; Cummings et al., 2000; 
Ferns and McClaughry, 2013) associated with Oregon-Idaho Graben subsidence reactivated the ring fault system at McIntyre Ridge and dropped the McIntyre Ridge lava sequence stepwise down to the east (Fig. 3). As a result, the prominent intracaldera intrusion of Three Fingers Rock now sits topographically higher than McIntyre Ridge.

Delineating the eastern margin of the caldera between McIntyre Ridge and Mahogany Mountain depends upon establishing which of the several lavas and intrusions exposed in the area are pre-caldera and post-caldera in age. We have used phenocryst abundance and trace-element concentrations to correlate individual outcrops of lava to those of known pre- and post-caldera age. Scattered outcrops northwest of Bannock Ridge (mapped as Bannock Ridge rhyolite lava by Vander Meulen et al. (1987a)) and lavas west of and Smith Butte (Fig. 3) contain 10\% phenocrysts of feldspar>quartz and have the high $\mathrm{Zr}(\sim 425 \mathrm{ppm})$ and relatively low $\mathrm{Ba}(\sim 300$ ppm) concentrations typical of intracaldera post-caldera rhyolites. In contrast, the lava of Round Mountain ( $\sim 15 \%$ feldspar $\sim 1 \mathrm{~cm}$ long and $\sim 7 \%$ quartz up to $4 \mathrm{~mm})$ is a petrographic and chemical match (Fig. 10) for the more mafic, low-silica rhyolite of the 11.6 Ma Jump Creek Rhyolite (Bonnichsen et al., 2004). Hence, it is included in Fig. 3 as part of the younger Owyhee Front Rhyolites, and its location does not constrain the margin of the caldera.

In addition, drill logs from 150-m exploration holes drilled by ASARCO south of McIntyre Ridge can be used to place the eastern caldera margin near the Katie gold prospect (Fig. 2). Holes east of the prospect intersected $\sim 30 \mathrm{~m}$ of tuffaceous sediment overlying $>120 \mathrm{~m}$ of massive basalt, which we interpret as Sucker Creek Formation over tholeiitic basalts (e.g., lower Bishop's Ranch basalt of Kittleman et al. (1965) and Ferns (1989)) outboard of the caldera. Holes west of the prospect encountered only sediments and intercalated rhyolite lava, which we interpret as caldera fill.

The southeastern topographic margin of the caldera is covered by the 15.6 Ma Mahogany Mountain rhyolite lavas. These lavas erupted along what we interpret to be the ring fracture, and although some of the lavas flowed north into the caldera, interacting with caldera lake sediments, most of the lavas flowed south of the caldera.

The southwestern margin of the caldera is obscured by Quaternary basalts and massive landslides (Ferns et al., 1993b; Ely et al., 2012) and by lavas, including the McCain Creek rhyolite lava of Ferns et al. (1993b), that we correlate with the voluminous 11.6 Ma Jump Creek Rhyolite (Bonnichsen et al., 2008) based on a similar chemical composition that is distinct from Rooster 
Comb Caldera rhyolites (Fig. 10). We have included outcrops near Blue Canyon that were considered Birch Creek rhyolite lava by Plumley (1986) and Ferns et al. (1993b) within these younger Owyhee Front rhyolites on Fig. 3, based on continuity with mapped Owyhee Front rhyolite lavas and on the lack of hornblende and biotite phenocrysts characteristic of the Birch Creek rhyolite.

The Tuff of Leslie Gulch is banked in against Birch Creek rhyolite southwest of Blue Canyon (Fig. 3). The ignimbrite is thick at this location, $\sim 120 \mathrm{~m}$ with the base unexposed, which is why we interpret the exposure as intracaldera ignimbrite ponded against caldera wall consisting of truncated Birch Creek rhyolite lava. We acknowledge, however, that it could represent outflow filling a paleocanyon outboard of the caldera. Much of what has been mapped by Ferns et al. (1993b) as Tuff of Leslie Gulch near the southwest margin of the caldera we find to be tuffaceous sediment. Further mapping is required in this region to distinguish between these units, and to truly constrain the caldera margin.

The western and northern margins of the caldera are poorly constrained due to cover by Mid- to Late Miocene basaltic lavas and a thick sequence of tuffaceous lacustrine and fluvial sediments associated with subsidence of the Oregon-Idaho Graben (e.g., Brown and Petros, 1985; Cummings and Gowney, 1988; Cummings, 1991a,b; Ferns et al., 1993a,b; Cummings et al., 2000; Ferns and McClaughry, 2013). At Red Butte (Fig. 3), these sediments are overprinted by epithermal gold mineralization in a Late Miocene fossil hydrothermal system (Evans, 1986; Rytuba and Vander Meulen, 1991; Zimmerman and Larson, 1994). It is possible that the mineralization marks the western caldera margin, as a ring-fracture zone would provide permeability for ascent of deeper hydrothermal fluids (Rytuba, 1994). This is the case along the eastern margin of the caldera, where the mineralizing fluids at the $\sim 12$ Ma Katie gold prospect (Fig. 2) appear to have made use of the significantly older eastern ring-fracture zone of the Rooster Comb Caldera (Vander Meulen et al., 1989a; Rytuba et al., 1991; Rytuba and Vander Meulen, 1991; Zimmerman, 1991; Rytuba, 1994).

The presence or absence of faults can be used to help locate the caldera margins in places covered by Late Miocene to Quaternary rocks and deposits. Crystallized magma chambers form plutons that are stronger than surrounding sedimentary and volcanic wallrocks, inhibiting the propagation of faults. This phenomenon is observed at the Mid-Miocene calderas at High Rock Caldera Complex and McDermitt Volcanic Field (Fig. 1), where normal faults associated with 
Basin and Range extension offset units adjacent to the calderas but not within the calderas themselves (Rytuba et al., 2013; Coble and Mahood, in press). At the Rooster Comb Caldera, major faults are nearly absent within the intracaldera section but are present east of the caldera beginning at McIntyre Ridge. Faulting is minor from the Owyhee Reservoir to Red Butte, but west of Red Butte normal faults offset stratigraphy, suggesting that Red Butte marks the western edge of the Rooster Comb Caldera.

We tentatively place the north-northwestern caldera margin where outcrops of the intracaldera ignimbrite end along the northern edge of the Honeycombs. At this location numerous dikes and sills of plagioclase-rich mafic lava crosscut the intracaldera ignimbrite; they decrease in abundance toward the center of the caldera. The age of these intrusions is unknown, though their abundance along the edge of the intracaldera tuff suggests that the magma may have taken advantage of existing structural weaknesses along the ring-fracture system. The sedimentary rocks that formed the topographic wall of the caldera in this location were likely preferentially eroded away compared to the vapor-phase altered intracaldera tuff at the Honeycombs. A similar inversion of topography at a caldera margin occurs at the Virgin Valley Caldera in the High Rock Caldera Complex, Nevada, where post-caldera rhyolite lavas banked in against a caldera margin composed of basinal sediments. Subsequent erosion left an arcuate cliff composed of the rhyolite lava (Coble and Mahood, in press).

\subsection{Estimate of the area of the Rooster Comb Caldera and volume of intracaldera tuff}

Using the foregoing evidence we tentatively delineate a caldera margin that is $\sim 20 \times 25$ $\mathrm{km}$. Given that topographic margins of calderas lie 1-2 km outboard of the ring fracture zone (e.g., Lipman, 1997), adjusting all but the highly speculative western boundary, which is located based on evidence for where the ring-fracture zone lies, $1 \mathrm{~km}$ inward yields a main zone of collapse that has an area of $\sim 350 \mathrm{~km}^{2}$. Due to the lack of preserved outflow ignimbrite, it is not possible to estimate accurately the total eruptive volume of the Tuff of Leslie Gulch. Assuming a minimum thickness of $700 \mathrm{~m}$ for the intracaldera ignimbrite (the amount exposed in Leslie Gulch), the intracaldera Tuff of Leslie Gulch has a minimum volume of $\sim 250 \mathrm{~km}^{3}$.

\section{Discussion}

5.1 Comparison of Rooster Comb Caldera rhyolites to other Mid-Miocene caldera complexes 


\subsubsection{Caldera sizes}

Rooster Comb Caldera is similar in size to calderas that have been mapped at other MidMiocene rhyolitic caldera complexes associated with Steens/Columbia River Basalt flood lavas (Fig 1.). At High Rock Caldera Complex, the four major calderas range in size from $\sim 30$ x $40 \mathrm{~km}$ to $\sim 24 \times 28 \mathrm{~km}$ (Coble and Mahood, in press). At McDermitt Volcanic Field, the calderas range in size from $\sim 40 \times 30 \mathrm{~km}$ for the McDermitt Caldera (Henry et al., 2012) to $\sim 7 \times 7 \mathrm{~km}$ for the Whitehorse Caldera (Benson and Mahood, 2015).

\subsubsection{Composition}

The peralkalinity of the Tuff of Leslie Gulch, the postcaldera intracaldera rhyolite lavas and intrusions, and Rattlesnake Den rhyolite, as reflected in their moderately high Zr, LREE, and $\mathrm{Nb}$ concentrations (Fig. 10, Appendix A) and in sodic sanidine being the sole feldspar, sets them apart from other units in LOVF. The Cottonwood Mountain and Dooley Mountain rhyolites appear to be metaluminous in composition (agpaitic indices of $\sim 0.75-0.85$ and $\mathrm{Zr}<300 \mathrm{ppm}$; Evans, 1989; Binger, 1997; Ferns and McClaughry, 2013). Rytuba et al. (1991) and Cummings et al. (2000) report that the Dinner Creek Tuff is peralkaline, but given that it has significantly lower $\mathrm{Zr}$ and slightly lower REE concentrations than the weakly peralkaline Tuff of Leslie Gulch (Fig. 8), contains 1-3\% phenocrysts of Na-rich plagioclase (Evans and Binger, 1997; Johnson et al., 1998; Streck et al., 2015), rather than the single alkali feldspar that is typical of peralkaline rhyolites, and chemical analyses of vitrophyre and pumice reported by Streck et al. (2015) yield an agpaitic index of $\sim 0.8$, we conclude it is metaluminous.

The relatively high $\mathrm{Zr}$, Nb, and REE contents of many Rooster Comb rhyolites are typical for peralkaline magmas and are similar to those of ignimbrites in the McDermitt and High Rock caldera complexes (Rytuba and McKee, 1984; Conrad, 1984; Benson et al., 2013; Coble and Mahood, in press). The Tuff of Leslie Gulch, however, has higher concentrations of Ba, 500-2000 ppm. Only the highly evolved tuff of the Honeycombs has the very low concentrations $(<100$ ppm) found in most of the rhyolites of McDermitt Volcanic Field and High Rock Caldera Complex (Fig. 8). This elevation of Ba was noted by Nash and Perkins (2012) in other voluminous rhyolites in LOVF, the Dinner Creek Tuff and Mascall Tuff. Peralkaline rhyolites generally have low Ba concentrations due to extensive fractionation of sodic sanidine and/or anorthoclase rich in Ba (Mahood and Stimac, 1990). The relatively higher values of Ba (and Nb, Fig. 8) in LOVF may 
reflect a crustal component in the magmas that is more granitic than the mafic transitional crust on which the McDermitt and High Rock caldera complexes are located.

\subsection{Change in type of sediments deposited before and after 15.8 Ma eruption of Tuff of Leslie}

\section{Gulch records initial basin subsidence}

Cummings et al. (2000) identified a large, north-south-trending, synvolcanic basin called the Oregon-Idaho Graben (Fig. 1), which began to subside after eruption of Columbia River Basalt Group flood lavas, and was a locus of sedimentation until 10.5 Ma. Cummings et al. (2000) and Ferns and McClaughry (2013) noted that initial subsidence of the graben was accompanied by collapse of silicic calderas, including the source area for the Dinner Creek Tuff and what we term the Rooster Comb Caldera. The prominent north-south alignment of postcaldera intracaldera rhyolite dikes in the Rooster Comb Caldera (Fig. 3) was taken to reflect the east-west-directed extension of the graben. They placed the age of onset of subsidence at between $\sim 15.5$ and 15.3 Ma, based on locations where they observed sediments onlapping rhyolites related to the Rooster Comb Caldera. The higher precision ${ }^{40} \mathrm{Ar} /{ }^{39} \mathrm{Ar}$ ages for LOVF rhyolites reported here makes it possible to refine this age estimate.

The oldest unit we have identified at Rooster Comb Caldera is the 15.9 Ma precaldera McIntyre Ridge rhyolite, which conformably overlies shallow lacustrine and lakeshore deposits that characterize the lower part of the Mid-Miocene Sucker Creek Formation (e.g., Downing, 1992). Consistent with this constraint on the age of the lower part of the formation, Nash and Perkins (2012) chemically correlated the lower of two ashes within bentonitic claystone at a locality about $20 \mathrm{~km}$ southeast of the Succor Creek Campground (Barbara Nash, personal communication, 2015) with the Mascall Tuff, which was dated as 15.8 Ma by Swisher (1992) at the type locality of the Mascall Formation. In Succor Creek and Sage Creek, outflow of the 15.81 Ma Tuff of Leslie Gulch filled valleys cut in this lower part of the Sucker Creek Formation.

Given that the vertebrate-fossil-bearing fluvial and subaerial upper part of the Sucker Creek Formation contains ashes yielding ages of about 15.2 to 14.9 Ma (see section 3.1.1 above), it appears that the Tuff of Leslie Gulch erupted around the time of a transition from a lacustrine to a fluvial and subaerial environment.

There is a similar stratigraphic relationship between the 15.8 Mascall Tuff, presumed to be sourced from the central LOVF, and the Mid-Miocene Mascall Formation, noted for its fossil flora 
and fauna. As described by Bestland et al. (2008), the Lower Mascall Formation was deposited conformably on Picture Gorge Basalt (a member of Grande Ronde Basalt), and consists of lignitic and diatomaceous siltstones and claystones deposited in a freshwater, eutrophic lake (based on the presence of the diatom Actinocyclus krasskei (Krebs and Bradbury, 1982; Bradbury and Krebs, 1995)). In contrast, coarser alluvial floodplain and channel deposits that host Barstovian mammalian fauna and numerous soil horizons characterize the Middle and Upper Mascall Formation. The Mascall Tuff occurs at the base of the Middle Mascall Formation, marking the transition from lacustrine to floodplain and subaerial conditions.

We speculate that the lower parts of the Sucker Creek Formation and Mascall Formation were deposited in freshwater lake environments created by damming of drainages by extensive flood basalt lavas, and that the upper parts were deposited beginning around 15.8 Ma when we suggest that extension associated with the formation of the Oregon-Idaho Graben began and created the relief that allowed breaching of lava-dammed lakes and deposition of somewhat coarser deposits of alluvial plains and fluvial environments in extensional basins. The type Mascall Formation lies northwest of the Oregon-Idaho Graben, suggesting that other basins in Oregon also began opening at $\sim 15.8 \mathrm{Ma}$.

\subsection{Phreatomagmatic origin for Tuff of Leslie Gulch}

Our mapping suggests that a significant fraction of the circumference of the Rooster Comb caldera wall was comprised of lacustrine and lakeshore sediments of the Sucker Creek Formation, which have since been eroded away or covered by younger sediments and volcanic products. Support for this lies in the scarcity of lithics and lack of lithic megabreccia entrained in the intracaldera ignimbrite. If the wallrocks were largely unconsolidated sediments, they would have been pulverized in the eruption column and during emplacement, and would not have formed the steep cliffs required to get massive rock falls from growing caldera walls. This raises the possibility that water, either from a shallow lake or saturated sediments, gained access to the vent during eruption of the Tuff of Leslie Gulch. A phreatomagmatic origin and cool emplacement of the tuff would be consistent with (1) the scarcity of pumice lapilli due to the preponderance of fine ash formed in phreatomagmatic eruptions, (2) local presence of low-angle cross stratification within the tuff, (3) interbedding with fall deposits, (4) the presence of spheroidal features in the tuff that may have formed as accretionary lapilli, and (5) the scarcity of evidence for welding 
within the intracaldera ignimbrite despite its great thickness - all features observed in the wellstudied phreatoplinian rhyolitic 26.5 ka Oruanui eruption of New Zealand (Self and Sparks, 1978; Wilson, 2001). A phreatomagmatic origin would also account for why there is so little outflow sheet preserved: if water gained access to the vent and the eruption became phreatomagmatic, any pyroclastic density flows produced would have had a low aspect ratio and would have been too cool and thin to weld, resulting in low preservation potential. Finally, the intense zeolitization of the intracaldera tuff suggests that water was involved in the eruption and/or had access to intracaldera ignimbrite while it was still warm, accelerating the formation of zeolites.

\subsection{Interpretation of Conditions of Post-Depositional Alteration of the Tuff of Leslie Gulch}

We can assess the degree to which alteration in the ignimbrite is due to regional burial diagenesis as opposed to caldera-related zeolitization and hydrothermal alteration by comparing it to the alteration found in the contemporaneous ash-rich Sucker Creek Formation. Altaner and Grim (1990) found a bentonite (montmorillonite)-dominated facies that they concluded formed in sediments that had a volcanic protolith of intermediate composition, based on the Fe-rich composition of the smectite and the presence of crystals of pyroxene and andesine plagioclase. This is consistent with our mapping that shows that intermediate lavas intrude and are intercalated in the lower part of the Sucker Creek Formation in the area in which Altaner and Grimm (1990) sampled sections along Succor Creek. In sections that still contain vitric rhyolitic ash-based on our mapping, somewhat higher in the Sucker Creek Formation - alteration products that formed in favorable horizons were dominated by K-clinoptilolite and opal-CT. They concluded that both of these diagenetic assemblages formed in an open hydrologic setting, based on the absence of sodic zeolites that might otherwise be expected in a closed lake settings (Hay, 1963), and on the relatively dilute composition of the fluid (400-600 ppm total dissolved solids) they calculated to be in equilibrium with the K-clinoptilolite. Locally, sediments containing rhyolitic ash underwent further alteration in which overgrowths of $\mathrm{Ca}$-clinoptilolite and recrystallization of opal-CT to quartz, which Altaner and Grimm (1990) interpreted as indicating low-temperature $\left(\sim 75-125^{\circ} \mathrm{C}\right)$ hydrothermal conditions because there is no evidence that the sediments of the Sucker Creek Formation were buried to the several kilometers depth necessary to reach these temperatures (assuming a geothermal gradient of $35^{\circ} \mathrm{C} / \mathrm{km}$ ).

As discussed in 2.2, the intracaldera Tuff of Leslie Gulch is variably altered, with those 
areas containing the zeolites clinoptilolite \pm mordenite being less resistant to erosion than the areas altered to albite \pm quartz. Thus the alteration in the "Tuff of Spring Creek" is similar in grade to regional diagenesis found in the Sucker Creek Formation, though the intensity of the zeolitization in the intracaldera ignimbrite is much greater. The presence of mordenite \pm heulandite \pm analcime and albite \pm quartz alteration assemblages in other parts of the intracaldera ignimbrite require higher temperatures. For example, in diagenetically altered silicic volcaniclastic sediments, with increasing depth and, therefore, temperature, rhyolitic glass is replaced in the sequence clinoptilolite ( \pm mordenite) -- analcime -- albite in sodic systems (i.e., those in which the sum of the alkali earth activity/hydrogen ion activity is large) or by clinoptilolite \pm mordenite -- analcime \pm heulandite - laumontite -- albite (Iijima, 1980, Utada, 2001). In the Sanzugawa volcano-tectonic depression, where there is a present-day elevated geothermal gradient of $>175^{\circ} \mathrm{C} / \mathrm{km}$, assemblages found with increasing depth are clinoptilolite $>$ mordenite --mordenite $>$ clinoptilolite - analcime laumontite -- wairakite (Utada, 2001). The latter is similar to the assemblages found by Bargar and Keith (1995) in the modern Yellowstone hydrothermal system.

Although the intracaldera ignimbrite at Rooster Comb Caldera contains alteration assemblages that are found with increasing depth within Miocene ignimbrites at Yucca Mountain, Nevada (e.g., Broxton et al., 1987, Chipera and Apps, 2001) and with increasing grades of diagenetic alteration with depth in Japanese marine silicic tuffs (Iijima, 1980) and caldera environments (Utada, 2001; Bargar and Keith, 1995), the nature and the orientation of the contacts between alteration zones is not consistent with alteration being due solely to burial. First, the lowest-temperature clinoptilolite-bearing assemblage is found at the deepest exposed levels of the intracaldera section. In fact, the type locality of the "Tuff of Spring Creek" occurs at the level of Lake Owyhee (TB-167 in Appendix A). Second, in many localities within the caldera (as exemplified in the outcrop pictured in Fig. 5a) ignimbrite characterized by clinoptilolite and previously mapped as Tuff of Spring Creek (e.g., TB-419A in Fig. 5a) grades horizontally or subhorizontally through transitional tuff containing mordenite \pm heulandite \pm analcime into tuff with the albite \pm quartz alteration assemblage (TB-421A) over a distance of tens of meters to hundreds of meters. Such transitions are best explained as resulting from relatively strong horizontal temperature gradients, rather than burial depth.

The higher temperature albite \pm quartz alteration within the Rooster Comb Caldera occurs in two settings: (1) locally in ignimbrite that lies above where we locate the caldera ring-fracture 
zone, and (2) near the margins of rhyolite dikes and lava domes. In both these settings, elevated temperatures would be expected: deep, warm fluids would be channeled to shallow depths along ring-fracture zones, and intrusions would heat interstitial fluids in the adjacent ignimbrite, driving flow. Close to post-caldera rhyolite dikes, the tuff is characterized by albite \pm quartz; tens to hundreds of meters away, the assemblage transforms to mordenite \pm heulandite \pm analcime, and, distally, to clinoptilolite-bearing tuff. Where dikes are abundant in the central part of Leslie Gulch the bulk of the ignimbrite is characterized by albite \pm quartz alteration. This transition is similar to that observed in the Obispo Formation in southern California, where rhyodacite tuff adjacent to intrusions is mordenite-bearing and the lower-temperature clinoptilolite-bearing tuff occurs distally (Surdam and Hall, 1984). In the Sanzugawa volcano-tectonic depression, the ambient diagenetic sodic zeolites pass to calcic, higher-temperature zeolites adjacent to intrusions (Utada, 2001). At the Oligocene Caetano Caldera, Nevada, spatial patterns of alteration in intracaldera ignimbrite are controlled both by depth within the caldera and proximity to post-caldera intrusions (John et al., 2011).

It is difficult to estimate the alteration temperatures from the zeolite assemblages in the intracaldera Tuff of Leslie Gulch because the temperature stability fields of all the zeolites in rhyolitic tuffaceous rocks are strongly affected by (1) silica activity as controlled by the presence of various silica polymorphs and (2) the capacity of the zeolites to exchange extrastructural cations. The results of Altaner and Grimm (1990) establish that the alteration assemblage one would expect to form in the rhyolitic ignimbrite of the Tuff of Leslie Gulch from diagenesis under open hydrologic conditions would be dominated by clinoptilolite + opal-CT. The alteration assemblage found in the areas that were previously mapped as the green-colored "Tuff of Spring Creek" is indeed dominated by clinoptilolite, though in this intracaldera environment the zeolitization was more intense. The formation of heulandite and analcime in areas transitional in characteristic between the "Tuff of Spring Creek" and the Tuff of Leslie Gulch suggests higher temperatures, because with increasing temperature and decreasing silica activity, the stability fields of heulandite and analcime expand at the expense of clinoptilolite (Chipera and Apps, 2001). A minimum estimate for the temperature of this transition is likely to be given by the temperature for conversion of opal-CT to quartz, $\sim 80^{\circ} \mathrm{C}$ (Keller and Isaacs, 1985) assuming that the resulting decrease in silica activity led to formation of analcime (Neuhoff, 1999; Neuhoff et al., 2004). The presence of albite \pm quartz in the more resistant tan outcrops mapped as the Tuff of 
Leslie Gulch requires even higher temperatures. The transition from analcime-bearing to albitebearing in diagenetically altered vitric tuffs from Japan is estimated to be $\sim 125^{\circ} \mathrm{C}$ (Iijima, 1978). Given the presence of quartz, phase boundaries calculated at pressures corresponding to liquidvapor equilibrium (Neuhoff et al., 2004) are consistent with a somewhat higher transition temperature, $\sim 150^{\circ} \mathrm{C}$. We did not detect the Ca-rich zeolites that Bargar and Keith (1995) found in altered rhyolite at higher temperatures (wairakite $\sim 140-200^{\circ}$, laumontite $\sim 160-200^{\circ} \mathrm{C}$, and rare yugawaralite $>200^{\circ} \mathrm{C}$ ) in the active hydrothermal system at Yellowstone; however, we cannot use their absence to rule out higher temperature fluids because these phases may not have been able to form in the Ca-poor Tuff of Leslie Gulch.

We suggest that the extensive development of zeolites and low-temperature hydrothermal alteration in the intracaldera Tuff of Leslie Gulch may be a result of the eruption being phreatomagmatic. In their study of the Neapolitan Yellow Tuff, de'Gennaro et al. (2000) explained the unusual patterns of zeolitization in the outflow facies of this trachytic to phonolitic deposit as a result of its origin in a highly explosive phreatomagmatic eruption. The extensive zeolitization was attributed to thicker accumulations of highly fragmented tuff emplaced at a temperature close to that of water condensation such that there was sufficient water to enhance hydration-dissolution of this highly reactive glass. The situation at Leslie Gulch differs in that the glass, being rhyolitic, was not as reactive. On the other hand, the accumulation of a great thickness of ignimbrite within the collapsing caldera created an "autoclave" environment in which water was contained and elevated temperatures maintained such that zeolitization was enhanced.

\subsection{Updating and Refining the Definition of the Lake Owyhee Volcanic Field}

\subsubsection{Original definition}

In defining Lake Owyhee Volcanic Field, Rytuba et al. (1991) highlighted six moderatevolume ignimbrites as being sourced from the field: the Dinner Creek Tuff in the north, the Tuff of Leslie Gulch and "Tuff of Spring Creek" in the southeast part of the field, and the Wildcat Creek tuff, tuff of Crowley, and the Birch Creek Tuff in the southwest. In this section we synthesize subsequent work and our own reconnaissance observations regarding ages of units to refine the assignment of units to the LOVF. We do this to create parity with the High Rock Caldera Complex and McDermitt Volcanic Field, both of which contain several rhyolitic calderas 
that formed over a period of $<1$ my in the Mid-Miocene closely following eruptions of flood basalts in the region. In refining the definition, the spatial and temporal link of LOVF silicic magmatism to the Columbia River Basalt flood volcanism is strengthened, and, when combined with information about High Rock and McDermitt caldera complexes, gives a more accurate impression of the extent of silicic volcanism contemporaneous with Steens/Columbia River Basalt flood lavas.

\subsubsection{Dinner Creek Tuff, Mascall Ignimbrite, Mascall Tuff, and the Dinner Creek Eruptive Center}

The largest preserved ignimbrite in LOVF is the Dinner Creek Tuff (Rytuba et al., 1991; Streck et al., 2015) A source near Castle Rock in east-central Oregon (CR in Fig. 1) has been suggested by most workers (Haddock, 1967; Wood, 1976; Rytuba et al., 1991; Streck and Ferns, 2004; Ferns and McClaughry, 2013; Streck et al., 2015), with Rytuba et al. (1991) proposing the existence of a 12 - by $20-\mathrm{km}$ caldera, based on the presence of thick sections of Dinner Creek Tuff and "tuff breccia" (Lowry, 1968). Other workers argue that a source farther east, near the margin of the Oregon-Idaho Graben (OIG in Fig. 1), is more consistent with thickness relations and the abundance of lithics in the ignimbrite (Evans, 1996; Evans and Binger, 1997; Evans and Binger, 1998b). Nash and Perkins (2012) estimate an age of 16.0 Ma for the Dinner Creek Tuff based on the stratigraphic position of the associated fall deposit in Mid-Miocene sedimentary sections.

In contrast to earlier workers, Streck et al. (2015) correlate widespread outcrops of MidMiocene ignimbrite previously mapped in the central part of the LOVF, including the Mascall Ignimbrite, to the Dinner Creek Tuff. They report six new ${ }^{40} \mathrm{Ar} /{ }^{39} \mathrm{Ar}$ ages ranging from 14.88 to 16.16 Ma, and conclude that the Dinner Creek Tuff is composed of at least four major cooling units that erupted over a period of $\sim 1$ my from a source they name the Dinner Creek Eruptive Center, north of Castle Rock (CR in Fig. 1). While not disputing that it is likely that many of these units are sourced from an as-yet unmapped caldera complex north and east of Castle Rock, we prefer not to lump discrete units erupted over a 1-my period under the name of a single ignimbrite, at least not in Tertiary volcanic fields in which more detailed mapping could determine the distribution of the individual units, and for which modern high-precision ${ }^{40} \mathrm{Ar} /{ }^{39} \mathrm{Ar}$ dating can resolve units erupted as little as $50 \mathrm{ky}$ apart in age.

The Mascall Tuff (as distinct from the Mascall Ignimbrite) is one of the most widespread ash-fall deposits of Mid-Miocene age, being found in sedimentary sections in Oregon, Idaho, 
Washington, and Nevada (Nash and Perkins, 2012). It is normally magnetized and occurs above the reversely magnetized, ash-fall equivalent of the Dinner Creek Tuff in these sections (Prothero et al. 2006; Nash and Perkins, 2012). Swisher (1992) determined a weighted mean ${ }^{40} \mathrm{Ar} /{ }^{39} \mathrm{Ar}$ age of $15.83 \pm 0.17 \mathrm{Ma}$ (recalculated to a FCs age of $28.02 \mathrm{Ma}$ ) at the type locality of the Mascall Formation in Picture Gorge. Given the similarity in age of the Mascall Tuff and the Tuff of Leslie Gulch, we considered whether the Mascall Tuff could be a fall deposit associated with the Tuff of Leslie Gulch ignimbrite. Based solely on a comparison of our chemical analyses of the Tuff of Leslie Gulch with the analyses of the Mascall Tuff by Nash and Perkins (2012), they could be a match. However, Swisher (1992) determined the ${ }^{40} \mathrm{Ar} /{ }^{39} \mathrm{Ar}$ age on plagioclase, whereas we find that sodic sanidine (Or30-40) is the dominant feldspar in the Tuff of Leslie Gulch, making their correlation unlikely.

\subsubsection{Dooley Mountain}

Ferns and McClaughry (2013) included in the northern part of the LOVF the rhyolitic center at Dooley Mountain (DM in Fig. 1), where the presence of a section of high-silica rhyolite welded tuff 2,400 m thick, rheomorphism, tuff breccia with 2-m-diameter clasts, and pyroclastic dikes, as well as rhyolitic lava domes (Reef, 1983; Whitson, 1988; Bailey, 1990; Evans, 1992) hint at the presence of a caldera. Eruptive products of Dooley Mountain directly overlie the Dinner Creek Tuff (Bailey, 1990; Ferns and McClaughry, 2013), and Dooley Mountain rhyolite proper overlies basalt correlated with the Columbia River Basalt (Shervais and Hanan, 2008). Fiebelkorn

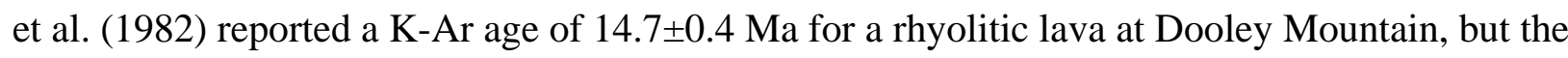
center is probably older, given that nearly all K-Ar ages of that vintage from LOVF have turned out to be $\sim 0.5 \mathrm{Ma}$ younger than ${ }^{40} \mathrm{Ar} /{ }^{39} \mathrm{Ar}$ ages obtained in the last five years.

\subsubsection{Cottonwood Mountain rhyolite lavas and Littlefield Rhyolite}

Ferns and McClaughry (2013) included in their discussion of the Lake Owyhee Volcanic Field thick, large-volume, regionally extensive, low-silica rhyolitic lavas known to overlie the Dinner Creek Tuff: the lavas of Cottonwood Mountain (Cummings et al., 2000) and the overlying Littlefield Rhyolite (Kittleman et al., 1965) (CM and LR in Fig. 1). The two units are difficult to distinguish in the field because they both contain sparse plagioclase and pyroxene phenocrysts and form morphologically similar thick, coalescing, lobate masses (Ferns and McClaughry (2013). 
They differ in the details of their phenocryst mineralogy (see Hooper et al., 2002, Supplementary Material), and they can be distinguished chemically (Binger, 1997) because the Littlefield Rhyolite has considerably higher $\mathrm{TiO}_{2}$ and higher $\mathrm{FeO}^{*}$ and $\mathrm{Zr}$ concentrations than the Cottonwood Creek Rhyolite (Fig. 10). Because it is hard to assign lavas to the two units in the field in the absence of petrographic and chemical data, there have been differences of interpretation regarding their stratigraphic relationship with the Hunter Creek Basalt (Kittleman et al., 1965; Lees, 1994; Binger, 1998; Cummings et al., 2000; Hooper et al., 2002; Ferns and Streck, 2004; Ferns and McClaughry, 2013). There have also been different interpretations of the origin of these bodies, with Lees (1994) and Hooper et al. (2002) citing the presence of lithics and superwelded glass-shard textures in support of the Littlefield Rhyolite being a rheomorphic ignimbrite, consistent with the great lateral extent $(>50 \mathrm{~km})$ of the unit. We include the Cottonwood Mountain rhyolitic lavas (which are low-silica rhyolites given that they have $~ 72-74 \mathrm{wt} \% \mathrm{SiO}_{2}$; Binger, 1997) but exclude the Littlefield Rhyolite from the LOVF based on the currently available geochemical and stratigraphic evidence. Existing geochronological data for the rhyolites are not of sufficient accuracy, precision, or quantity to resolve the issue ${ }^{6}$.

There is agreement that Cottonwood Creek low-silica rhyolite lavas lie stratigraphically below the Hunter Creek Basalt, and some workers have mapped the lavas above as well. The Hunter Creek Basalt is an icelandite (Fe-rich andesite) that is thought to be the last of the Grande Ronde Basalt to erupt in this area (Hooper et al., 2002; Ferns and McClaughry, 2013). ${ }^{40} \mathrm{Ar} /{ }^{39} \mathrm{Ar}$ age for the basalt of $15.89 \pm 0.26 \mathrm{Ma}$ (Lees, 1994, reported in Cummings et al., 2000) is consistent with the estimate by Jarboe et al. $(2008,2010)$ and Baksi (2013) that Grande Ronde Basalts erupted until ca. 16.0 Ma.

The Littlefield Rhyolite overlies the Cottonwood Mountain low-silica rhyolite lavas. The ambiguous textural features reported by Lees (1994) and Hooper et al. (2002) are similar to the

\footnotetext{
${ }^{6}$ Samples of what was mapped as Cottonwood Mountain rhyolite lavas have yielded ${ }^{40} \mathrm{Ar} /{ }^{39} \mathrm{Ar}$ ages of $15.24 \pm 0.31 \mathrm{Ma}$

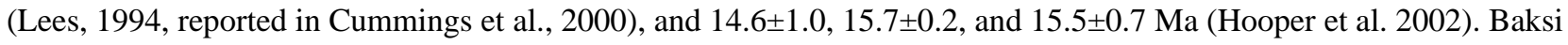
(2013) has argued that nearly all the ages reported in Hooper et al. (2002) are too young by 0.5-1 my because the samples were altered. The existing ages for the Littlefield lavas (K-Ar age of 17.5 Ma (Fiebelkorn et al., 1982) and an ${ }^{40} \mathrm{Ar} /{ }^{39} \mathrm{Ar}$ age of $16.6 \mathrm{Ma}$ (Hooper et al., 2002)) are too old for their stratigraphic position above the $\sim 16.0 \mathrm{Ma}$ Dinner Creek Tuff. To our knowledge there are no dated units with Mid-Miocene ages directly above the Littlefield Rhyolite lavas.
} 
features documented by Bonnichsen et al. (2004) in the high-temperature Late Miocene Owyhee Front rhyolites. Chemically, the Littlefield Rhyolite more closely resembles the younger, lowsilica rhyolite, 11.6 Ma Jump Creek Rhyolite and the other Owyhee Front rhyolites than the MidMiocene rhyolites of LOVF (Fig. 10). Consistent with a probable Late Miocene age for the Littlefield Rhyolite are the observations of Cummings et al. (2000) that suggest that the Littlefield Rhyolite erupted after considerable subsidence had taken place along the Oregon-Idaho Graben: the Littlefield Rhyolite banks against scarps of the graben and overlies fanglomerate that contains cobbles of the basalt of Malheur Gorge.

\subsubsection{Centers west of $L O V F$}

Rytuba and Vander Meulen (1991) included rhyolitic ignimbrites and lavas west of Rooster Comb Caldera near Saddle Butte and Crowley (Fig. 1) in their original definition of the LOVF. This area has not been well studied, but we conclude based on previous work and our own reconnaissance that these units are likely to be Late Miocene in age rather than Mid-Miocene.

Rytuba and Vander Meulen (1991) suggested that a possible caldera at Saddle Butte (SB in Fig. 1) was the source for the Birch Creek Tuff. Our work on lavas at and around Saddle Butte indicates that they are neither a chemical nor petrographic match to the metaluminous hornblende+biotite-bearing lavas and minor tuffs near Birch Creek in the southeastern LOVF (Fig. 3). An arcuate pattern of outcrops of alkali rhyolite lavas ringing Saddle Butte, which is itself a rhyolitic lava cut by apical-graben-like faults, is suggestive of a caldera; however, the area is largely covered by basaltic lavas (which are probably Quaternary based on the presence of lava tubes). To our knowledge, the rhyolitic lavas have not been dated. Ferns et al. (1993b) include them in their Late Miocene late bimodal suite.

Similarly, the Wildcat Creek tuff and the tuff of Crowley, which were originally included in the LOVF by Rytuba and Vander Meulen (1991), are probably younger than other units in LOVF. The Wildcat Creek tuff is stratigraphically above the Tims Peak Basalt (Ferns et al., 1993b), which Evans (1990) correlates with the 12.5 Ma Shumway Ranch Basalt (Fiebelkorn et al., 1982), and is below the 9.6 Ma (Ford et al., 2013) Devine Canyon Tuff (Ferns et al., 1993b).

Previous mapping near the Crowley Ranch (C in Fig. 1) (Rytuba and Vander Meulen, 1991; Ferns et al., 1993b; Evans and Binger, 1999a; Evans and Binger, 1999b) indicates that there are rhyolite lavas and several relatively small ignimbrites, but further work is required to 
determine if any of them are caldera-forming units and whether they are Mid-Miocene in age. It seems more likely that silicic volcanism in this area is Late Miocene in age and is associated with the Newberry/High Lava Plains Trend (Ford et al., 2013), given that it is located near the initiation point of this westward-younging trend of small centers dominated by rhyolitic lava domes (Fig. 1).

\subsubsection{Implication of refinement of assignment to centers to LOVF}

In this paper we have described the Rooster Comb caldera in the southern LOVF. We suggest that overlapping calderas that are the sources for the Dinner Creek Tuff, Mascall Ignimbrite, and other units (Streck et al., 2015) are yet to be delineated in the central LOVF, and that there is likely to be a caldera at Dooley Mountain in the northern part of the LOVF. Perkins and Nash (2002) and Nash and Perkins (2012) report data for several widespread unnamed tuffs with ages in the range 15.6-15.4 Ma that have the combination of elevated $\mathrm{Ba}$ and moderate $\mathrm{Zr}$ characteristic of the weakly alkalic LOVF rhyolites. There may be as-yet undetected Mid-Miocene calderas and centers belonging to the LOVF buried by the younger Owyhee Front volcanic rocks and Late Miocene sedimentary rocks of the Oregon-Idaho Graben.

By refining the assignment of rhyolitic centers to the LOVF to include only centers that are known or highly likely to be Mid-Miocene in age we reduce the size of the field, and changes its shape to one that is elongate in a NNW direction. This makes clearer the relationship of the rhyolitic centers of the LOVF to dikes of the Chief Joseph swarm and the associated Grande Ronde Basalt (Fig. 1).

\subsection{Mid-Miocene silicic calderas track northward migration of the focus of flood basalt lavas}

Shervais and Hanan (2008) and Coble and Mahood (2012) noted the spatial and temporal relationship of Mid-Miocene silicic caldera centers and Steens/Columbia River flood basalt volcanism, and Camp (2013) described how the ages of the rhyolites reflect the ages of nearby flood basalts. Our new ages and redefinition of LOVF make clear just how closely large MidMiocene silicic magmatic systems in northern Nevada and southeastern Oregon follow the timeprogressive northward migration observed in the lavas and feeder dikes of the Columbia River Basalt Group.

Our new ${ }^{40} \mathrm{Ar} /{ }^{39} \mathrm{Ar}$ data for the Rooster Comb Caldera show that volcanism occurred from $\sim 15.9$ to $15.6 \mathrm{Ma}$, punctuated by the eruption of the Tuff of Leslie Gulch at 15.8 Ma. Northeast of 
the caldera, outflow sheet directly overlies the Fe-rich olivine tholeiitic andesite lavas of the lower Bishop's Ranch basalt (Ferns, 1989), possible high-Al equivalents to the upper Grande Ronde Basalt (Ferns and McClaughry, 2013). In central LOVF, the Dinner Creek Tuff erupted at 16.0 Ma, and related ignimbrites and tuffs erupted for the next $~ 1$ my (Nash and Perkins, 2012; Streck et al., 2015). In Malheur Gorge, the Dinner Creek Tuff overlies R1 MSU of the Grande Ronde Basalt, and is overlain by Hunter Creek Basalt, another Fe-rich andesite that is interpreted as equivalent to the uppermost Grande Ronde basalts (Hooper et al., 2002; Reidel et al., 2013). The Dooley Mountain rhyolite lava proper directly overlies the Dooley Mountain Basalt (Evans, 1992), which is accepted as a part of the Columbia River Basalt (Shervais and Hanan, 2008).

Precise estimates of the time interval between eruptions of Grande Ronde Basalt flood lavas and the development of major silicic volcanism in LOVF is hindered by the fact that existing age estimates for the Grande Ronde Basalt lavas are inconsistent in the literature. Barry et al. (2013) use predominantly groundmass ${ }^{40} \mathrm{Ar} /{ }^{39} \mathrm{Ar}$ ages to conclude that eruptions occurred ca. 16 to ca. 15.6 Ma, whereas Jarboe et al. (2008; 2010) and Baksi (2013) arrive at somewhat earlier ages for the eruptions, between $\sim 16.2$ and $\sim 16.0$ (adjusted to a FCs age of $28.02 \mathrm{Ma}$ ), based on his assessment of the existing plagioclase ${ }^{40} \mathrm{Ar} /{ }^{39} \mathrm{Ar}$ ages of the $\mathrm{R}_{1} / \mathrm{N}_{0}, \mathrm{~N}_{1} / \mathrm{R}_{1}, \mathrm{R}_{2} / \mathrm{N}_{1}$, and $\mathrm{N}_{2} / \mathrm{R}_{2}$ magnetostratigraphic boundaries within the $\mathrm{C} 5 \mathrm{Cn}$ chron. An "older" chronology is more consistent with the position of the $\sim 16.0$ Ma Dinner Creek Tuff within a section of basalts equivalent to the uppermost Grande Ronde Basalt in Malheur Gorge, and with the observation that flood basalt volcanism that is correlated to the upper Grande Ronde Basalt (the lower Bishop's Ranch Basalt) ceased in the southern LOVF before eruption of the 15.81 Ma Tuff of Leslie Gulch. The application of an older chronology is consistent with the finding by Prothero et al. (2006) of a reversely magnetized equivalent of the 16.0 Ma Dinner Creek Tuff within the lower part of the Mascall Formation and the normally magnetized 15.8 Ma Mascall Tuff at the base of the middle of the Mascall Formation, the base of which is conformable with the Dayville Basalt Formation of the Picture Gorge Basalt Subgroup (Bailey, 1989). This would be consistent with the $\mathrm{N}_{2} / \mathrm{R}_{2}$ transition occurring at $\sim 15.9$ Ma.

Using this older chronology, the silicic magmatism of the LOVF occurred during the waning stages of Grande Ronde Basalt eruptions, some $\sim 0.2$ my after their onset (Fig. 13). Silicic activity appears to have continued for another $\sim 1$ my in the northern and central LOVF after Grande Ronde Basalts cased erupting in the region (based on the available 15 Ma ages for 
Dooley Mountain (Evans, 1992) and the youngest units in the Dinner Creek Eruptive Center (Streck et al., 2015)).

The rhyolitic volcanism of the High Rock Caldera Complex and the McDermitt Volcanic field stand in the same temporal relationship to the Steens Basalt as the LOVF rhyolites do to the Grande Ronde Basalt, erupting late in the history of these spatially associated flood basalts. Steens Basalts are thought to be $16.9-16.4 \mathrm{Ma}$, with most of the volume having erupted 16.7-16.6 Ma (Jarboe et al., 2008, 2010; Coble and Mahood, 2012; Barry et al., 2013; Baksi, 2013; Coble and Mahood, in press). The earliest Mid-Miocene rhyolites dated at High Rock and McDermitt volcanic complexes erupted ca. 16.6 Ma (Henry et al., 2006; Coble and Mahood, in press), with the first major caldera-forming ignimbrite from each caldera complex capping sections of Steens Basalt (Jarboe et al., 2010; Coble and Mahood, in press). Silicic volcanism at High Rock Caldera Complex and McDermitt Volcanic Field began $\sim 0.3$ my after the beginning of Steens flood basalt eruptions, and the caldera-forming volcanism - indicating the development of sizable upper crustal magma chambers — began $\sim 100$ ky later, or $\sim 200$ ky after the peak in Steens Basalt eruptions 16.7-16.6 Ma. Major silicic volcanism continued until 15.6 Ma at High Rock Caldera Complex (Coble and Mahood, in press) and 15.4 Ma at McDermitt Volcanic Field (Benson and Mahood, 2015), i.e., 1 my after silicic volcanism began and flood basalts ceased erupting in the area, as observed in LOVF (Fig. 13).

The relationship of the Silver City eruptive center in westernmost Idaho (SC in Fig. 1) with flood lavas is also consistent with the idea that the rhyolitic centers track the propagation of flood basalt dikes northward. The description by Pansze (1975) of thick densely welded ignimbrites, lithic-rich "tuff breccias", and vent breccias in addition to rhyolite lavas suggest the presence of a significant rhyolitic center, although the existing studies at the mining district scale (e.g., Halsor et al., 1988; Hasten, 2012) have not identified a caldera. The Silver City rhyolites overlie basalt lavas (Pansze, 1975). Aseto (2012) reports a ${ }^{40} \mathrm{Ar} /{ }^{39} \mathrm{Ar}$ plateau age of $16.08 \pm 0.18 \mathrm{Ma}$ on plagioclase for a basalt and 15.94 $\pm 0.10 \mathrm{Ma}$ on sanidine phenocrysts from the overlying rhyolite. Camp et al. (2013) "very tentatively" correlate the Silver City basalts with the Imnaha Basalt, but Hasten (2012) reports analyses of basaltic lavas (undated) that span a range of compositions similar to those of the Upper Steens, Imnaha, and Grande Ronde basalts.

We interpret the available stratigraphic and geochronological evidence from Mid-Miocene rhyolitic centers as indicating that the rhyolitic centers track the time-progressive northward 
propagation of giant flood basalt dikes along zones of crustal weakness at the boundary between the North American craton and accreted terrains (e.g., Glenn and Ponce, 2002; Pierce et al., 2002; Wolff et al., 2008; Coble and Mahood, 2012; Camp, 2013), with voluminous rhyolites forming where the dikes intruded fertile transitional crust at the craton margin (Coble and Mahood, 2012). The dikes propagated from an area centered on what is now the northern end of Steens Mountain (Fig. 1) from what we interpret as the location of the initial impingement of the plume on the North American lithosphere at $\sim 17 \mathrm{Ma}$. (We note that this conclusion echoes the results of Wolff et al. (2008, in particular their Fig. 1) who came to their conclusions based on an entirely independent data set, the isotopic compositions of the flood basalts.) Steens Basalt dikes propagated south-southeast, south, and south-southwest to fuel silicic volcanism within the Northern Nevada Rift, McDermitt Volcanic Field, and High Rock Caldera Center, respectively; dikes were emplaced to the north-northeast to create Silver City eruptive center; and the LOVF was associated with emplacement of the Chief Joseph dike swarm and eruption of Grande Ronde Basalt lavas.

In each sector around the focus of flood basalt dikes, major Mid-Miocene rhyolitic centers closely followed the eruption of flood basalt in the particular region, as evidenced that their products lie directly on flood basalt lavas. The first caldera-forming silicic eruptions occur during the waning stages of the associated flood basalts (Fig. 13), typically marking the end of flood basalt volcanism in the area in and around the silicic center, although flood basalts of the same subgroup may continue to erupt elsewhere. This suggests that eruptions of flood basalt end in any particular area when sizable bodies of low-density silicic magma accumulate in midcrustal melt zones and upper crustal silicic magma reservoirs (e.g., Smith, 1979). We suggest, however, that basaltic dikes continued to be injected beneath the major caldera complexes in order to fuel the silicic volcanism that continues for 0.5-1 my after flood basalts ceased eruption. The smallervolume Mid-Miocene rhyolitic centers scattered over $\sim 25,000 \mathrm{~km}^{2}$ of northern Nevada and southeastern Oregon (Fig. 1; Coble and Mahood, 2012) may be a result of less intense intrusion by flood basalts or intrusion of mafic magmas generated in the asthenosphere due to the impingement of a plume head. The contrast in the orientation of the calderas within the High Rock Caldera Complex, McDermitt Volcanic Field, and Lake Owyhee Volcanic Field with the overall trend of silicic centers that make up the Snake River Plain/Yellowstone trend (Fig. 1) can be attributed to 
the trends of giant flood basalt dike zones that radiated from the plume head, as opposed to the Miocene to Recent track of the proposed Yellowstone plume tail.

\section{Summary}

We have reinterpreted the Mid-Miocene geology in the southeastern part of Lake Owyhee Volcanic Field suggests that a single ignimbrite, the Tuff of Leslie Gulch, erupted during collapse of a ca. 20 x $25 \mathrm{~km}$ caldera we call the Rooster Comb Caldera. New trace and minor element geochemical data show that locations previously mapped as the Tuff of Leslie Gulch and "Tuff of Spring Creek" overlap in composition, and new ${ }^{40} \mathrm{Ar} /{ }^{39} \mathrm{Ar}$ ages on alkali feldspar phenocrysts from both facies are indistinguishable at $\sim 15.8 \mathrm{Ma}$. Previously mapped contacts between intracaldera Tuff of Leslie Gulch and "Tuff of Spring Creek" are gradational, reflecting differences in alteration. Locations previously mapped as "Tuff of Spring Creek" consist of intracaldera ignimbrite that was subjected to low-temperature diagenetic alteration $\left(\sim 100^{\circ} \mathrm{C}\right)$ to clinoptilolite \pm mordenite, whereas outcrops previously mapped as the Tuff of Leslie Gulch have an alteration assemblage of quartz and albite, consistent with hydrothermal alteration at higher temperatures (up to $\left.175^{\circ} \mathrm{C}\right)$.

The earliest Mid-Miocene rhyolites in the region are the Birch Creek low-silica rhyolite lavas erupted at $\sim 16.8 \pm 1.1 \mathrm{Ma}$. Given its phenocryst assemblage of plagioclase, amphibole, and biotite and its metaluminous composition, is unlikely to be closely related to the Rooster Comb magmatic system. The $15.9 \mathrm{Ma}$ McIntyre Ridge rhyolite lava dome is the first unit we associate with the Rooster Comb Caldera. It and the Birch Creek low-silica rhyolite were truncated by the collapse of the Rooster Comb Caldera on eruption of the Tuff of Leslie Gulch at 15.81 Ma.

Post-caldera rhyolitic activity occurred ca. 15.8 to $15.6 \mathrm{Ma}$. Intracaldera rhyolites, although somewhat similar in composition to the Tuff of Leslie Gulch, are more evolved (lower $\mathrm{TiO}_{2}$ and $\mathrm{FeO}^{*}$ concentrations) and show lower $\mathrm{Zr}$ indicative of metaluminous magmas in which zircon is a fractionating phase. Resurgent uplift focused on the southwestern part of the caldera culminated in eruption at $15.6 \mathrm{Ma}$ of the Mahogany Mountain composite dome along the southern ring fracture and the Rattlesnake Den rhyolite lavas southwest of the caldera. Due to this uplift, subsequent erosion in the southwestern part of the caldera exposed thick intracaldera Tuff of Leslie Gulch cut by numerous rhyolite dikes and sills; equivalents of these intrusions presumably fed lavas and plugs erupted through caldera-lake sediments preserved in the northeastern part of the caldera. 
Rhyolites in LOVF are closely related in space and time to flood basalt volcanism. The northward migration in silicic activity from the High Rock and McDermitt centers to the LOVF with time mirrors the northward migration of both feeder dikes and lava flows from the Steens Basalt to the Grande Ronde Basalt of the Columbia River Basalt Group. The cessation of nearly all flood basaltic volcanism at the three silicic fields prior to the caldera-forming eruptions suggests that the large influx of basaltic magmas to the crust caused partial melting that served as density barrier for rise of subsequent basalts. Thereafter, the less-dense silicic magmas erupted until basaltic underplating ceased as the focus of basaltic influx migrated northward. Eruptive products of LOVF date a change at $\sim 15.8 \mathrm{Ma}$ in the depositional environments from lacustrine to subaerial midway through the Mid-Miocene Sucker Creek Formation and Mascall Formation, marking the initiation of regional extensional event that included formation of the Oregon-Idaho graben.

\section{Acknowledgements}

We thank Maxine Luckett, Ian Hagmann, and Sebastian Belfanti for their efforts as field assistants, Mark Ferns for introducing us to the rocks in LOVF, Donald Applebee of ASARCO for providing drill logs, Prof. Marty Grove for assistance with geochronology, and especially Philip Neuhoff for guidance in interpreting the zeolites. We are grateful for constructive reviews by Neuhoff and two anonymous journal reviewers that led to significant improvements in presentation. Partial funding for this project was provided by a McGee Fund Grant from Stanford University and by a Department of Defense National Defense Science and Engineering Graduate Fellowship awarded to Benson. 


\section{References}

Altaner, S.P., Grim, R.E., 1990. Mineralogy, Chemistry, and Diagenesis of Tuffs in the Sucker Creek Formation (Miocene), Eastern Oregon. Clays and Clay Minerals, 38, 6, 561-572.

Armstrong, R.L., Taubeneck, W.H., Hales, P.O., 1977. Rb-Sr and K-Ar geochronometry of Mesozoic granitic rocks and their Sr isotopic composition, Oregon, Washington, and Idaho. Geological Society of America Bulletin, 88, 397-411.

Aseto, C.O., 2012. Geology, Geochemistry and Geochronology of the mid-Miocene, LowSulfidation Epithermal Gold-Silver Ores on War Eagle Mountain, Silver City District, Idaho. M.S. Thesis, Auburn University, 170 p.

Bailey, M.M., 1989. Revisions to stratigraphic nomenclature of the Picture Gorge Basalt Subgroup, Columbia River Basalt Group. Geological Society of America Special Papers, 239, $67-84$.

Bailey, D.G., 1990. Geochemistry and petrogenesis of Miocene volcanic rocks in the Powder River volcanic field, northeastern Oregon. Ph.D. Thesis, Washington State University, 341 p.

Baksi, A.K., 2013. Timing and duration of volcanism in the Columbia River Basalt Group: A review of existing radiometric data and new constraints on the age of the Steens through Wanapum Basalt extrusion. Geological Society of America Special Papers, 497, 3, 67-85. doi: 10.1130/2013.2497(03).

Bargar K.E., Keith, T.E.C., 1995. Calcium zeolites in rhyolitic drill cores from Yellowstone National Park, Wyoming. In: Ming, D.W., Mumpton, F.A. (Eds.), Natural Zeolites '93: Occurrence, Properties, Use. Intl. Comm. on Natural Zeolites, Brockport, New York, pp. 6986.

Barry, T.L., Kelley, S.P., Reidel, S.P., Camp, V.E., Self, S., Jarboe, N.A., Duncan, R.A., Renne, P.R., 2013. Eruption chronology of the Columbia River Basalt Group. Geological Society of America Special Papers, 297, 45-66. doi:10.1130/2013.2497(02). 
Benson, T.R., Mahood, G.A., Coble, M.A., 2013. An Intense 16.5-16.0 Ma Episode of Rhyolitic Volcanism Associated with Flood Basalt Dike Emplacement at McDermitt Caldera Field and High Rock Caldera Complex, Nevada and Oregon. Abstract V33E-2828, 2013 Fall Meeting, American Geophysical Union, San Francisco, CA.

Benson, T.R., Mahood, G.A., 2015. The Oldest Known Caldera Associated with the Yellowstone Hotspot: New Geologic Mapping, Geochemistry, and 40Ar/39Ar Geochronology for the Northern McDermitt Volcanic Field, Northern Nevada and Southeastern Oregon. Abstract V24C-85816, 2015 Fall Meeting, American Geophysical Union, San Francisco, CA.

Bestland, E.A., Forbes, M.S., Krull, E.S., Retallack, G. J., Fremd, T., 2008. Stratigraphy, paleopedology, and geochemistry of the middle Miocene Mascall Formation (type area, central Oregon, USA). PaleoBios, 28, 2, 41-61.

Binger, G.B., 1997. The Volcanic Stratigraphy of the Juntura Region, Eastern Oregon. M.S. Thesis, Washington State University, 176 p.

Bonnichsen, B., McCurry, M., Godchaux, M.M., 2004. Miocene Snake River Plain rhyolites of the Owyhee Front, Owyhee County, Idaho. In: Haller, K.M., Wood, S.H. (Eds.), Geological Field Trips in Southern Idaho, Eastern Oregon, and Northern Nevada. Department of Geosciences, Boise State University, Boise, ID, pp. 154-173.

Bonnichsen, B., Leeman, W.P., Honjo, N., McIntosh, W.C., Godchaux, M. M., 2008. Miocene silicic volcanism in southwestern Idaho: geochronology, geochemistry, and evolution of the central Snake River Plain. Bulletin of Volcanology, 70, 3, 315-342. doi:10.1007/s00445-0070141-6

Bradbury, J.P., Krebs, W.N., 1995. The diatom genus Actinocyclus in the western United States. U.S. Geological Survey Professional Paper 1543A-B, 73 p.

Brooks, H.C, O'Brien, J.P., 1992. Geology and mineral resources map of the Westfall quadrangle, Malheur County, Oregon: Oregon Department of Geology and Mineral Industries Geological Map Series, GMS-71, scale 1:24,000. 
Brown, D.E., Petros, J.R., 1985. Geochemistry, geochronology, and magnetostratigraphy of a measured section of the Owyhee Basalt. Oregon Geology, 47, 2, 15-20.

Broxton, D.E., Bish, D.L., Warren, R.G., 1987. Distribution and chemistry of diagenetic minerals at Yucca Mountain, Nye County, Nevada. Clays and Clay Minerals, 35, 2, 89-110.

Brueseke, M.E., Hart, W.K., 2008. Geology and Petrology of the mid-Miocene Santa Rosa-Calico Volcanic Field, Northern Nevada. Nevada Bureau of Mines and Geology Bulletin, 113, 44 p.

Brueseke, M.E., Hart, W.K., Heizler, M.T., 2008. Diverse mid-Miocene silicic volcanism associated with the Yellowstone-Newberry thermal anomaly. Bulletin of Volcanology, 70, 3, 343-360. doi:10.1007/s00445-007-0142-5

Brueseke, M.E., Callicoat, J.S., Hames, W., Larson, P.B., 2014. Mid-Miocene rhyolite volcanism in northeastern Nevada: The Jarbidge Rhyolite and its relationship to the Cenozoic evolution of the northern Great Basin (USA). Geological Society of America Bulletin, 126, 7-8, 10471067. doi:10.1130/B30736.1

Bryan, S.E., Ernst, R.E., 2008. Revised definition of large igneous provinces (LIPs). EarthScience Reviews, 86, 175-202.

Bryan, S.E., Peate, I.U., Peate, D.W., Self, S., Jerram, D.A., Mawby, M.R., Marsh, J.S., Miller, J.A., 2010. The largest volcanic eruptions on Earth. Earth-Science Reviews, 102, 3-4, 207229. doi: 10.1016/j.earscirev.2010.07.001

Camp, V.E., 2013. Origin of Columbia River Basalt: Passive rise of shallow mantle, or active upwelling of a deep-mantle plume? Geological Society of America Special Papers, 497, 7, 181-199. doi:10.1130/2013.2497(07).

Camp, V.E., Ross, M.E., Hanson, W.E., 2003. Genesis of flood basalts and Basin and Range volcanic rocks from Steens Mountain to the Malheur River Gorge, Oregon. Geological Society of America Bulletin, 115, 1, 105-128. doi:10.1130/0016-7606(2003)115<0105 
Camp, V.E., Ross, M.E., Duncan, R.A., Jarboe, N.A., Coe, R.S., Hanan, B.B., Johnson, J.A. (2013). The Steens Basalt: Earliest lavas of the Columbia River Basalt Group. Geological Society of America Special Papers, 497, 87-116. doi:10.1130/2013.2497(04).

Chipera, S.J., Apps, J.A., 2001. Geochemical Stability of Natural Zeolites. Reviews in Mineralogy and Geochemistry, 45, 1, 117-161. doi:10.2138/rmg.2001.45.3

Christiansen, E. H., McCurry, M., 2008. Contrasting origins of Cenozoic silicic volcanic rocks from the western Cordillera of the United States. Bulletin of Volcanology, 70, 3, 251-267. doi: 10.1007/s00445-007-0138-1

Christiansen, R.L., Yeats, R.S., 1992. Post- Laramide geology of the U.S. Cordilleran region. In: Burchfiel, B.C., Lipman, P.W., Zoback, M.L.C. (Eds.), The Cordilleran orogen: Conterminous U.S., Geological Society of America, Boulder, Colorado, pp. 261-406.

Coble, M.A., Mahood, G.A., 2012. Initial impingement of the Yellowstone plume located by widespread silicic volcanism contemporaneous with Columbia River flood basalts. Geology, 40, 7, 655-658. doi:10.1130/G32692.1

Coble, M.A., Mahood, G.A., in press. Geology of the High Rock Caldera Complex, northwest Nevada, and implications for intense rhyolitic volcanism associated with flood basalt magmatism and the initiation of the Snake River Plain/Yellowstone trend. Geosphere.

Conrad, W.K., 1984. The mineralogy and petrology of compositionally zoned ash flow tuffs, and related silicic volcanic rocks, from the McDermitt Caldera Complex, Nevada-Oregon. Journal of Geophysical Research, 89, B10, 8639-8664.

Courtillot, V.E., Renne, P.R., 2003. On the ages of flood basalt events. Comptes Rendus Geoscience, 335, 1, 113-140.

Criss, R.E., Fleck, R.J., 1987. Petrogenesis, geochronology, and hydrothermal systems of the northern Idaho batholith and adjacent areas based on 18O/16O, D/H, 87Sr/86Sr, and 40Ar/39Ar studies. U.S. Geological Survey Professional Paper, 1436, 95-138. 
Cross, A.T., Taggart, R.E., 1982. Causes of Short-Term Sequential Changes in Fossil Plant Assemblages: Some Considerations Based on a Miocene Flora of the Northwest United States. Annals of the Missouri Botanical Garden, 69, 3, 676-734.

Cummings, M.L., 1991a. Geology of the Deer Butte Formation, Malheur County, Oregon: faulting, sedimentation and volcanism in a post-caldera setting. Sedimentary Geology, 74, 1-4, 345-362. doi:10.1016/0037-0738(91)90072-L

Cummings, M.L., 1991b. Relations Among Volcaniclastic Sedimentation, Volcanism, Faulting, and Hydrothermal Activity West of Lake Owyhee, Malheur County, Oregon. In: Raines, G.L., Lisle, R.E., Schafer, R.W., Wilkinson, W.H. (Eds.), Geology and Ore Deposits of the Great Basin. Geological Society of Nevada, Reno, NV, pp. 111-132.

Cummings, M.L., Growney, L.P., 1988. Basalt hydrovolcanic deposits in the Dry Creek arm area of the Owyhee Reservoir, Malheur County, Oregon: Stratigraphic relations. Oregon Geology, $50,7,75-82$.

Cummings, M.L., Evans, J.G., Ferns, M.L., Lees, K.R., 2000. Stratigraphic and structural evolution of the middle Miocene synvolcanic Oregon-Idaho graben. Geological Society of America Bulletin, 112, 5, 668-682. doi:10.1130/0016-7606(2000)112<668

de'Gennaro, M., Cappelletti, P., Langella, A., Perrotta, A., Scarpati, C., 2000. Genesis of zeolites in the Neapolitan Yellow Tuff: geological, volcanological and mineralogical evidence: Contributions to Mineralogy and Petrology 139, 17-35.

Downing, K.F., 1992. Biostratigraphy, taphonomy, and paleoecology of vertebrates from the Sucker Creek Formation (Miocene) of southeastern Oregon. PhD Thesis, The University of Arizona, $485 \mathrm{p}$.

Downing, K.F., Swisher, C.C.I., 1993. New ${ }^{40} \mathrm{Ar} /{ }^{39} \mathrm{Ar}$ dates and refined geochronology of the Sucker Creek Formation, Oregon. Journal of Vertebrate Paleontology, 13, 3, p. 33A. 
Ekren, E.B., McIntyre, D.H., Bennett, E.H., 1984. High-temperature, large-volume, lava-like ashflow tuffs without calderas in southwestern Idaho. U.S. Geological Survey Professional Paper, $1272,1-76$.

Elison, M.W., Speed, R.C., Kistler, R.W., 1990. Geologic and isotopic constraints on the crustal structure of the northern Great Geologic and isotopic constraints on the crustal structure of the northern Great Basin. Geological Society of America Bulletin, 8, 1077-1092. doi:10.1130/0016-7606(1990)102<1077

Ellis, B.S., Branney, M.J., Barry, T.L., Barfod, D., Bindeman, I., Wolff, J.A., Bonnichsen, B., 2012. Geochemical correlation of three large-volume ignimbrites from the Yellowstone hotspot track, Idaho, USA. Bulletin of Volcanology, 74, 1, 261-277. doi: 10.1007/s00445-0110510-Z

Ely, L.L., Brossy, C.C., House, P.K., Safran, E.B., O’Connor, J.E., Champion, D.E., Fenton, C.R., Bondre, N.R., Orem, C.A., Grant, G.E., Henry, C.D., Turrin, B.D. (2012). Owyhee River intracanyon lava flows: Does the river give a dam? Geological Society of America Bulletin, 124, 11-12, 1667-1687. doi:10.1130/B30574.1

Evans, C.S., 1986. The geology, geochemistry, and alteration of Red Butte, Oregon: A precious metal-bearing paleo hot spring systems. M.S. Thesis, Portland State University, 133 p.

Evans, J.G., 1989. Analytical results for stream sediments, panned concentrates from stream sediments, and rock samples from the Dooley Mountain quadrangle, Baker County, Oregon. U.S. Geological Survey Open-File Report, 89-354.

Evans, J.G., 1990. Geology and Mineral Resources Map of the South Mountain Quadrangle, Malheur County, Oregon: Oregon Department of Geology and Mineral Industries Geological Map Series, GMS-67, scale 1:24,000.

Evans, J.G., 1992. Geologic Map of the Dooley Mountain 7 1/2' Quadrangle, Baker County, Oregon: U.S. Geological Survey Geologic Quadrangle Map, GQ-1694, 9 p., scale 1:24,000. 
Evans, J.G., 1996. Geologic map of the Monument Peak Quadrangle, Malheur County, Oregon: U.S. Geological Survey Miscellaneous Field Studies Map, MF-2317, scale 1:24,000.

Evans, J.G., Binger, G.B., 1997. Geologic map of the Westfall Butte Quadrangle, Malheur County, Oregon: U.S. Geological Survey Open-File Report, 97-481, scale 1:24,000.

Evans, J.G., Binger, G.B., 1998a. Geologic map of the Alder Creek Quadrangle, Malheur County, Oregon: U.S. Geological Survey Open-File Report, 98-494, scale 1:24,000.

Evans, J.G., Binger, G.B., 1998b. Geologic map of the Little Black Canyon Quadrangle, Malheur County, Oregon: U.S. Geological Survey Open-File Report, 98-493, scale 1:24,000.

Evans, J.G., Binger, G.B., 1999a. Preliminary geologic map of the Skull Springs quadrangle, Malheur County, Oregon: U.S. Geological Survey Open-File Report, 99-331, scale 1:24,000.

Evans, J.G., Binger, G.B., 1999b. Preliminary geologic map of the Star Creek Reservoir 7 1/2' quadrangle, Malheur County, Oregon: U.S. Geological Survey Open-File Report, 99-583, scale $1: 24,000$.

Evans, J.G., Griscom, A., Halvorson, P.F., Cummings, M.L., 2002. Tracking the Western Margin of the North American Craton Beneath Southeastern Oregon: A Multidisciplinary Approach. Idaho Geological Survey Bulletin, 30, 35-57.

Farmer, G.L., DePaolo, D.J., 1983. Origin of Mesozoic and Tertiary granite in the western United States and implications for Pre-Mesozoic crustal structure: 1. Nd and $\mathrm{Sr}$ isotopic studies in the geocline of the Northern Great Basin. Journal of Geophysical Research, 88, B4, 3379. doi:10.1029/JB088iB04p03379

Ferns, M.L., 1988. Geology and Mineral Resources Map of the Owyhee Ridge Quadrangle, Malheur County, Oregon: Oregon Department of Geology and Mineral Industries Geological Map Series, GMS-55, scale 1:24,000.

Ferns, M.L., 1989. Geology and Mineral Resources Map of the Graveyard Point Quadrangle, Malheur County, Oregon, and Owyhee County, Idaho: Oregon Department of Geology and Mineral Industries Geological Map Series, GMS-54, scale 1:24,000. 
Ferns, M.L., 1997. Field trip guide to the eastern margin of the Oregon- Idaho graben and the middle Miocene calderas of the Lake Owyhee volcanic field: Oregon Geology, 59, 9-20.

Ferns, M.L, Cummings, M.L., 1992. Geology and Mineral Resources Map of The Elbow Quadrangle, Malheur County, Oregon: Oregon Department of Geology and Mineral Industries Geological Map Series, GMS-62, scale 1:24,000.

Ferns, M.L., O’Brien, J.P., 1992. Geology and Mineral Resources Map of the Namorf Quadrangle, Malheur County, Oregon: Oregon Department of Geology and Mineral Industries Geological Map Series, GMS-74, scale 1:24,000.

Ferns, M.L., McClaughry, J.D., 2013. Stratigraphy and volcanic evolution of the middle Miocene to Pliocene La Grande-Owyhee eruptive axis in eastern Oregon. Geological Society of America Memoir, 497, 401-427. doi:10.1130/2013.2497(16).

Ferns, M.L., Brooks, H.C., Evans, J.G., Cummings, M.L., 1993a. Geologic Map of the Vale 30' by 60' Quadrangle, Malheur County, Oregon and Owyhee County, Idaho: Oregon Department of Geology and Mineral Industries Geologic Map Series, GMS-77, 12 p., scale 1:100,000.

Ferns, M.L., Evans, J.G., Cummings, M.L., 1993b. Geologic Map of the Mahogany Mountain 30' $\times 60^{\prime}$ Quadrangle, Malheur County, Oregon, and Owyhee County, Idaho: Oregon Department of Geology and Mineral Industries Geologic Map Series, GMS-78, 12 p., scale 1:100,000.

Fiebelkorn, R.B., Walker, G.W., Macleod, N.S., McKee, E.H., Smith, J.G., 1982. Index to K-Ar determinations for the State of Oregon. U.S. Geological Survey Open-File Report, 82-596.

Fleck, R.J., Criss, R.E., 1985. Strontium and oxygen isotopic variations in Mesozoic and Tertiary plutons of central Idaho. Contributions to Mineralogy and Petrology, 90, 291-308.

Fleck, R.J., Criss, R.E., 2007. Location, Age, and Tectonic Significance of the Western Idaho Suture Zone. U.S. Geological Survey Professional Paper, 1738, 202 p.

Ford, M.T., Grunder, A.L., Duncan, R.A., 2013. Bimodal volcanism of the High Lava Plains and Northwestern Basin and Range of Oregon: Distribution and tectonic implications of ageprogressive rhyolites. Geochemistry, Geophysics, Geosystems, 14, 8, 2836-2857. 
Gaschnig, R.M., Vervoort, J.D., Lewis, R.S., Tikoff, B., 2011. Isotopic Evolution of the Idaho Batholith and Challis Intrusive Province, Northern US Cordillera. Journal of Petrology, 52, 12, 2397-2429. doi:10.1093/petrology/egr050

Glen, J.M., Ponce, D.A., 2002. Large-scale fractures related to inception of the Yellowstone hotspot. Geology, 30, 7, 647-650. doi:10.1130/00917613(2002)030<0647:LSFRTI>2.0.CO;2

Haddock, G.H., 1967, The Dinner Creek Welded Ash-Flow Tuff of the Malheur Gorge area, Malheur County, Oregon. Ph.D. Thesis, University of Oregon, 165 p.

Halsor, S.P., Bornhorst, T.J., Beebe, M., Richardson, K., Strowd, W.,1988. Geology of the DeLamar Silver Mine, Idaho - A Volcanic Dome Complex and Genetically Associated Hydrothermal System. Economic Geology, 83, 1159-1169.

Hart, W.K., Aronson, J.L., Mertzman, S.A., 1984. Areal distribution and age of low-K, highalumina olivine tholeiite magmatism in the northwestern Great Basin. Geological Society of America Bulletin, 95, 186-195.

Hasten, Z.L., 2012, Mid-Miocene magmatism in the Owyhee Mountains, ID: Origin and petrogenesis of volcanic rocks in the Silver City District. M.S. Thesis, Kansas State University, $222 \mathrm{p}$.

Hay, R.L., 1963. Stratigraphy and zeolitic diagenesis of the John Day Formation of Oregon. University of California Publication in Geological Science, 42, 199-262.

Henry, C.D., Castor, S.B., McIntosh, W.C., Heizler, M.T., Cuney, M., Chemillac, R., 2006. Timing of oldest Steens Basalt magmatism from precise dating of silicic volcanic rocks, McDermitt caldera and northwest Nevada volcanic field. Abstract V44C-08, 2006 Fall Meeting, American Geophysical Union, San Francisco, CA.

Henry, C.D., Castor, S.B., Starkel, W.A., Ellis, B.S., Wolff, J.A., Heizler, M.T., McIntosh, W.C., 2012. The McDermitt Caldera, NV-IR, USA: Geologic mapping, volcanology, mineralization, 
and high precision 40Ar/39Ar dating of early Yellowstone hotspot magmatism. Abstract V33B-2850, 2012 Fall Meeting, American Geophyisical Union, San Francisco, CA.

Hooper, P.R., Binger, G.B., Lees, K.R., 2002. Ages of the Steens and Columbia River flood basalts and their relationship to extension-related calc-alkalic volcanism in eastern Oregon. Geological Society of America Bulletin, 114, 1, 43-50. doi:10.1130/00167606(2002)114<0043:AOTSAC>2.0.CO;2

Hooper, P.R., Camp, V.E., Reidel, S.P., Ross, M.E., 2007. The origin of the Columbia River flood basalt province: Plume versus nonplume models. Geological Society of America Special Papers, 430, 635-668.

Iijima, A., 1978. Geologic occurrences of zeolites in marine environments. In: Sand, L.B., Mumpton, F.A. (Eds.), Natural Zeolites: Occurrence, Properties, Use, Pergamon Press, Elmsford, New York, pp. 175-198.

Iijima, A., 1980. Geology of natural zeolites and zeolitic rocks. In: Rees, L.V.C. (ed.), Proceedings of the Fifth International Conference on Zeolites, Heyden \& Co., London, p. 103-118.

Jarboe, N.A., Coe, R.S., Renne, P.R., Glen, J. M., Mankinen, E.A., 2008. Quickly erupted volcanic sections of the Steens Basalt, Columbia River Basalt Group: Secular variation, tectonic rotation, and the Steens Mountain reversal. Geochemistry, Geophysics, Geosystems, 9, 11.

Jarboe, N.A., Coe, R.S., Renne, P.R., Glen, J.M.G., 2010. The age of the Steens reversal and the Columbia River Basalt Group. Chemical Geology, 274, 158-168. doi:10.1016/j.chemgeo.2010.04.001.

John, D.A., Rockwell, B.W., Henry, C.D., and Colgan, J.P., 2011. Hydrothermal alteration of the late Eocene Caetano ash-flow caldera, north-central Nevada: A field and ASTER remote sensing study. In: Steininger, R., Pennell, B. (Eds.), Great Basin Evolution and Metallogeny Proceedings, Geological Society of Nevada 2010 Symposium, Reno, Nevada, p. 1055-1083. 
Johnson, J.A., Hooper, P.R., Hawkesworth, C.J., Binger, G.B., 1998. Geologic map of the Stemler Ridge quadrangle, Malheur County, eastern Oregon: U.S. Geological Survey Open-File Report, 98-105, scale 1:24,000.

Jordan, B.T., Grunder, A.L., Duncan, R.A., Deino, A.L., 2004. Geochronology of age-progressive volcanism of the Oregon High Lava Plains: Implications for the plume interpretation of Yellowstone. Journal of Geophysical Research, 109, B10202. doi:10.1029/2003JB002776

Keller, M.A., Isaacs, C.M., 1985. An evaluation of temperature scales for silica diagenesis in diatomaceous sequences including a new approach based on the Miocene Monterey Formation, California. Geo-Marine Letters, 5, 1, 31-35.

Kistler, R.W., Lee, D.E., 1989. Rubidium, Strontium, and Strontium Isotopic Data for a Suite of Granitoid Rocks from the Basin and Range Province, Arizona, California, Nevada, and Utah. U.S. Geological Survey Open-File Report, 89-199, 13 pp.

Kittleman, L.R., Green, A.R., Hagood, A.R., Johnson, A.M., McMurray, J.M., Russell, R.G., Weeden, D.A., 1965. Cenozoic stratigraphy of the Owyhee region, southeastern Oregon: Eugene, University of Oregon, Museum of Natural History Bulletin 1, 45 pp.

Krebs, W.N., Bradbury, J.P., 1982. Neogene lacustrine diatom biostratigraphy of western Snake River basin, Idaho and Oregon: American Association of Petroleum Geologists Bulletin, 66, $10,1693$.

Lawrence, D.C., 1988. Geology and revised stratigraphic interpretation of the Miocene Sucker Creek Formation, Malheur County, Oregon. M.S. Thesis, Boise State University, 67 p.

Leeman, W.P., Oldow, J.S., Hart, W.K., 1992. Lithosphere-scale thrusting in the western U.S. Cordillera as constrained by $\mathrm{Sr}$ and $\mathrm{Nd}$ isotopic transitions in Neogene volcanic rocks. Geology, 20, 63-66.

Leeman, W.P., Annen, C., Dufek, J., 2008. Snake River Plain - Yellowstone silicic volcanism: implications for magma genesis and magma fluxes. Geological Society of London Special Publications, 304, 1, 235-259. doi: 10.1144/SP304.12 
Lees, K.R., 1994. Magmatic and tectonic changes through time in the Neogene volcanic rocks of the Vale area, Oregon, North Western USA. Ph.D. Thesis, The Open University, Milton Keynes, 284 p.

Lipman, P.W., 1997. Subsidence of ash-flow calderas: relation to caldera size and magmachamber geometry. Bulletin of Volcanology, 59, 3, 198-218.

Lowry, W.O., 1968, Geology of the Ironside Mountain quadrangle, Oregon. Oregon Department of Geology and Mineral Industries Open-File Report, scale 1:125,000, 79 p.

MacDonald, R., Bailey, D.K., 1973. Data of Geochemistry Sixth Edition: The Chemistry of the Peralkaline Oversaturated Obsidians. USGS Professional Paper, 440-N-1, 37 p.

MacLeod, N.S., 1990. Geology and mineral resources map of the Mahogany Gap quadrangle, Malheur County, Oregon. Oregon Department of Geology and Mineral Industries Geologic Map Series, GMS-65, scale 1:24,000.

Mahood, G.A., 1980. Geological Evolution of a Pleistocene Rhyolitic Center - Sierra La Primavera, Jalisco, Mexico. Journal of Volcanology and Geothermal Research, 8, 199-230.

Mahood, G.A., Stimac, J.A., 1990. Trace-element partitioning in pantellerites and trachytes. Geochimica et Cosmochimica Acta, 54, 8, 2257-2276. doi:10.1016/0016-7037(90)90050-U

Manduca, C.A., Silver, L.T., Taylor, H.P., $1992 .{ }^{87} \mathrm{Sr} /{ }^{86} \mathrm{Sr}$ and ${ }^{18} \mathrm{O} /{ }^{16} \mathrm{O}$ isotopic systematics and geochemistry of granitoid plutons across a steeply-dipping boundary between contrasting lithospheric blocks in western Idaho. Contributions to Mineralogy and Petrology, 109, 355372.

Nash, B.P., Perkins, M.E., 2012. Neogene fallout tuffs from the Yellowstone hotspot in the Columbia Plateau region, Oregon, Washington and Idaho, USA. PloS One, 7, 10, 1-13. doi:10.1371/journal.pone.0044205

Neuhoff, P.S., 1999. Thermodynamic properties and parageneses of rock-forming zeolites. Ph.D. Thesis, Stanford University, 240 pages. 
Neuhoff, P.S., Hovis, G.L., Balassone, G., Stebbins, J.F., 2004. Thermodynamic properties of analcime solid solutions. American Journal of Science, 304, 1, 21-66.

Pankhurst, M.J., Schaefer, B.F., Betts, P.G., 2011. Geodynamics of rapid voluminous felsic magmatism through time. Lithos, 123, 1-4, 92-101. doi: 10.1016/j.lithos.2010.11.014

Pansze, A. J., Jr., 1975. Geology and ore-deposits of the Silver City-DeLamar-Flint region, Owyhee County, Idaho, Pamphlet 161, Idaho Geological Survey, Moscow, 79 pp.

Perkins M.E., Nash, B.P., 2002. Explosive silicic volcanism of the Yellowstone hotspot: the ash fall tuff record. Geological Society of America Bulletin, 114, 367-381.

Pierce, K.L., Morgan, L.A., Saltus, R.W., 2002. Yellowstone plume head: Postulated tectonic relations to the Vancouver slab, continental boundaries, and climate, in Bill Bonnichsen, C.M. White, and Michael McCurry, eds., Tectonic and Magmatic Evolution of the Snake River Plain Volcanic Province: Idaho Geological Survey Bulletin 30, p. 5-33.

Plumley, P.S., 1986. Volcanic stratigraphy and geochemistry of the Hole in the Ground area, Owyhee Plateau, Southeastern Oregon. M.S. Thesis, University of Idaho, 161 pages.

Prothero, D.R., Draus, E., Foss, S.E., 2006. Magnetic stratigraphy of the lower portion of the middle Miocene Mascall Formation, central Oregon. PaleoBios, 26, 1, 37-42.

Reef, J.W., 1983. The Unity Reservoir rhyodacite tuff-breccia and associated volcanic rocks, Baker County, Oregon. Ph.D. Thesis, Washington State University, 128 pages.

Reidel, S.P., Camp, V.E., Tolan, T.L., Martin, B.S., 2013. The Columbia River flood basalt province: Stratigraphy, areal extent, volume, and physical volcanology. Geological Society of America Special Papers, 497, 1-43. doi:10.1130/2013.2497(01).

Renne, P.R., Swisher, C.C., Deino, A.L., Karner, D.B., Owens, T.L., DePaolo, D.J., 1998. Intercalibration of standards, absolute ages and uncertainties in 40Ar/39 Ar dating: Chemical Geology, 145, 117- 152. doi: 10.1016/S0009-2541(97)00159-9. 
Rytuba, J.J., 1994. Evolution of volcanic and tectonic features in caldera settings and their importance in localization of ore deposits. Economic Geology, 89, 8, 1687-1696. doi:10.2113/gsecongeo.89.8.1687

Rytuba, J.J., McKee, E.H., 1984. Peralkaline ash flow tuffs and calderas of the McDermitt Volcanic Field, southeast Oregon and north central Nevada. Journal of Geophysical Research, $89,8616-8628$.

Rytuba, J.J., Vander Muelen, D.B., 1991. Hot-Spring Precious-Metal Systems in the Lake Owyhee Volcanic Field, Oregon-Idaho. In: Raines, G.L., Lisle, R.E., Schafer, R.W., Wilkinson, W.H. (Eds.), Geology and Ore Deposits of the Great Basin. Geological Society of Nevada, Reno, NV, pp. 1085-1096.

Rytuba, J.J., Vander Meulen, D.B., and Minor, S.A., 1989, Geologic evolution of the Three Fingers caldera, Malheur County, Oregon: Geological Society of America Abstracts with Programs, 21, 5, p. 138.

Rytuba, J.J., Vander Meulen, D.B., Plouff, D., Minor, S.A., 1985. Geology of the Mahogany Mountain Caldera, Oregon: Geological Society of America Abstracts with Programs, 17, 4, p. 263.

Rytuba, J.J., Vander Muelen, D.B., Barlock, V.E., Ferns, M.L., 1991. Hot Spring Gold Deposits in the Lake Owyhee Volcanic Field, Eastern Oregon. In: Buffa, R.H., Coyner A.R. (Eds.), Great Basin Symposium: The Geology and Ore Deposits of the Great Basin: Field Trip Guidebook Compendium. Geological Society of Nevada, Reno, NV, pp. 633-712.

Rytuba, J.J., Blakely, R.J., Moring, B., Miller, R., 2013. Geophysical expression of caldera related volcanism, structures and mineralization in the McDermitt volcanic field. Abstract GP51C1103 presented at the 2013 Fall Meeting, AGU, San Francisco, CA, 9-13 December.

Self, S., Sparks, R.S.J., 1978. Characteristics of widespread pyroclastic deposits formed by the interaction of silicic magma and water. Bulletin Volcanologique, 41, 3, 196-212. 
Shervais, J.W., Hanan, B.B., 2008. Lithospheric topography, tilted plumes, and the track of the Snake River-Yellowstone hot spot. Tectonics, 27, 5, TC5004. doi: 10.1029/2007TC002181

Smith, R.L., 1979. Ash-flow magmatism. In: Chapin, C.E., Elston, W.E. (Eds.), Ash-flow tuffs. Geological Society of America Special Papers, 180, 5-28.

Starkel, W.A., 2014. Mapping, geologic evolution and petrogenesis of the McDermitt Caldera Center, northern Nevada \& southern Oregon, USA. Ph.D. Thesis, Washington State University, 393 pages.

Streck, M.J., Ferns, M.L., 2004. The Rattlesnake Tuff and Other Miocene Silicic Volcanism in Eastern Oregon. In: Haller, K.M., Wood, S.H. (Eds.), Geological Field Trips in Southern Idaho, Eastern Oregon, and Northern Nevada. Department of Geosciences, Boise State University, Boise, ID, pp. 2-17.

Streck, M.J., Ferns, M.L., McIntosh, W., 2015. Large, persistent rhyolitic magma reservoirs above Columbia River Basalt storage sites: The Dinner Creek Tuff Eruptive Center, eastern Oregon. Geosphere, 11, 2, 226-235. doi: 10.1130/GES01086.1

Surdam, R.C., Hall, C.A., Jr., 1984. Diagenesis of the Miocene Obisopo Formation, Coast Ranges, California, in Surdam., R.C. (ed.) A guidebook to the stratigraphic, tectonic, thermal and diagenetic histories of the Monterey Formation, Pismo and Huasna basin, California: Society of Economic Paleontologists and Mineralogists, Guidebook 2, 8-20.

Swisher, C.C.I., 1992. ${ }^{40} \mathrm{Ar} /{ }^{39} \mathrm{Ar}$ Dating and its Application to the Calibration of the North American Land Mammal Ages. Ph.D Thesis, University of California at Berkeley, 228 pages.

Tolan, T.L., Reidel, S.P., Beeson, M.H., Anderson, J.L., Fecht, K.R., Swanson, D.A., 1989. Revisions to the estimates of the areal extent and volume of the Columbia River Basalt Group. Geological Society of America Special Papers, 239, 1-20.

Unruh, B.D.M., Lund, K., Kuntz, M.A., Snee, L.W., 2008. Uranium-Lead Zircon Ages and Sr, $\mathrm{Nd}$, and $\mathrm{Pb}$ Isotope Geochemistry of Selected Plutonic Rocks from Western Idaho. U. S. Geological Survey Open-File Report, 2008-1142, 13 p. 
Utada, M., 2001. Zeolites in burial diagenesis and low-grade metamorphic rocks. Reviews in Mineralogy and Geochemistry, 45, 1, 305-322. doi: 10.2138/rmg.2001.45.9

Vander Meulen, D.B., 1989. Intracaldera Tuffs and Central-Vent Intrusion of the Mahogany Mountain Caldera, Eastern Oregon: U.S. Geological Survey Open-File Report, 89-77, 69 p., 2 plates, map scale 1:72,750.

Vander Meulen, D.B., , J.J., Grubensky, M.J., Goeldner, C.A., 1987a. Geologic Map of the Bannock Ridge Quadrangle, Malheur County, Oregon: U.S. Geological Survey Miscellaneous Field Studies Map, MF-1903, scale 1:24,000.

Vander Meulen, D.B., Rytuba, J.J., Grubensky, M.J., Vercoutere, T.L., Minor, S.A., 1987b. Geologic Map of the Pelican Point Quadrangle, Malheur County, Oregon: U.S. Geological Survey Miscellaneous Field Studies Map, MF-1904, scale 1:24,000.

Vander Muelen, D.B., Rytuba, J.J., King, H.D., Plouff, D., 1987c. Mineral Resources of the Honeycombs Wilderness Study Area, Malheur County, Oregon: U.S. Geological Survey Bulletin, 1741-A, 15 pages.

Vander Meulen, D.B., Rytuba, J.J., Vercoutere, T.L., Minor, S.A., 1987d. Geologic map of the Rooster Comb 7.5' quadrangle, Malheur County, Oregon: U.S. Geological Survey Miscellaneous Field Studies Map, MF-1902C, scale 1:24 000.

Vander Muelen, D.B., Griscom, A., King, H.D., Benham, J.R., 1989a. Mineral Resources of the Upper Leslie Gulch and Slocum Creek Wilderness Study Areas, Malheur County, Oregon: U.S. Geological Survey Bulletin, 1471-D, 15 pages.

Vander Meulen, D.B., Rytuba, J.J., Minor, S.A., Harwood, C.S., 1989b. Preliminary Geologic Map of the Three Fingers Rock Quadrangle, Malheur County, Oregon: U.S. Geological Survey Open-File Report, 89-344, scale 1:24,000.

Vander Meulen, D.B., Barlock, V.E., Plumley, P.S., Frisken, J.G., Griscom, A., Causey, J.D., 1990. Mineral Resources of the Blue Canyon and Owyhee Breaks Wilderness Study Areas, Malheur County, Oregon. U.S. Geological Survey Bulletin, 1741-G, 23 pages. 
Walker, G.W., 1979. Revisions to the Cenozoic Stratigraphy of Harney Basin, Southeastern Oregon: U.S. Geological Survey Bulletin, 1475, 35 p.

Wilson, C.J.N., 2001. The 26.5 ka Oruanui eruption, New Zealand: An introduction and overview. Journal of Volcanology and Geothermal Research, 112, 133-174. doi: 10.1016/S03770273(01)00239-6

Wolff, J.A., Ramos, F.C., Hart, G.L., Patterson, J.D., Brandon, A.D., 2008. Columbia River flood basalts from a centralized crustal magmatic system. Nature Geoscience, 1, 177-180. doi:10.1038/ngeo124

Wolff, J.A., Ellis, B.S., Ramos, F.C., Starkel, W.A., Boroughs, S., Olin, P.H., Bachmann, O., 2015. Remelting of cumulates as a process for producing chemical zoning in silicic tuffs: A comparison of cool, wet and hot, dry rhyolitic magma systems. Lithos, 236, 275-286.

Wood, J.D., 1976. The geology of the Castle Rock area, Grant, Harney, and Malheur Counties, Oregon. M.S. Thesis, Portland State University, 98 p.

Wooden, B.J.L., Kistler, R.W., Tosdal, R.M., 1999. Strontium, Lead, and Oxygen Isotopic Data for Granitoid and Volcanic Rocks from the Northern Great Basin and Sierra Nevada, California, Nevada and Utah. U.S. Geological Survey Open-File Report, 99-569, 20 pages.

Zimmerman, B.S., 1991. Geology and Geochemistry of Epithermal Gold Mineralization in the Lake Owyhee Volcanic Field-Western Snake River Plain Region of Eastern Oregon and Western Idaho. Ph.D. Thesis, Washington State University, 262 p.

Zimmerman, B.S., Larson, P.B., 1994. Epithermal gold mineralization in a fossil hot spring system, Red Butte, Oregon. Economic Geology, 89, 1983-2002. 


\section{FIGURE CAPTIONS}

\section{Fig. 1. Regional map highlighting Mid-Miocene ( 17-15 Ma) volcanic rocks in the Pacific}

Northwest. The extents of the members of the Columbia River Basalt Group (after Reidel et al. (2013)) and the generalized locations of feeder dikes (after Tolan et al. (1989) and Camp et al. (2003)) are shown. Dikes shown in light brown include Grande Ronde Basalt and younger members. Faint dashed lines indicate locations where older members of the Columbia River Basalt Group underlie the member shown at the surface. Contemporaneous silicic volcanism occurred within the High Rock, McDermitt, and Lake Owyhee volcanic centers, shown as lined fields with blue, green, and orange calderas, respectively. Caldera locations from Rytuba and McKee (1984), Rytuba and Vander Meulen (1991), Henry et al. (2012), Coble and Mahood (in press), and this study, and are labeled with the following symbols: R - Rooster Comb Caldera, CR - proposed Castle Rock caldera, WH - Whitehorse Caldera, M - McDermitt/Long Ridge Caldera(s), V Virgin Valley Caldera, B - Badger Mountain Caldera, H - Hanging Rock Caldera, CC Cottonwood Creek Caldera. Several Mid-Miocene small- to medium-volume lava centers are shown as yellow circles, and, for Lake Owyhee Volcanic Field, as orange circles. Lavas are identified as 17-15 Ma based on geochronological work and compilations of Walker (1979), Fielbelkorn et al. (1982), Jordan et al. (2004), Brueseke and Hart (2008), Coble and Mahood (2012, in press), Ford et al. (2013), Brueseke et al. (2014), and this study, and have the following symbols: DM - Dooley Mountain Volcanics, CM - rhyolite lavas of Cottonwood Mountain, LR Littlefield Rhyolite, SC - Silver City rhyolite, LJ - Little Juniper Mountain, HH - Horsehead Mountain, JB - Jackass Butte, SW - Swamp Creek Rhyolite, TM- Twenty Mile Creek Rhyolite, BB - Bald Butte, D - Drum Hill, HV - Hawks Valley-Lone Mountain center, S - Santa RosaCalico center, I - Ivanhoe, J - Jarbidge Rhyolite. The approximate margins of the Oregon-Idaho Graben are shown as thick black lines (after Cummings et al., 2000). Dashed lines with green outlines delineate approximate ages of rhyolites in the High Lava Plains/Newberry Trend (after Jordan et al. (2004), Ford et al. (2013)). Silicic centers less than 15 Ma associated with the Snake River Plain-Yellowstone trend shown in light green (after Camp et al., 2003; Ellis et al., 2012). Other symbols are as follows: SB - Saddle Butte, C - Crowley Ranch, NNR - Northern Nevada Rift (in light lavender). The 0.704 and $0.706{ }^{87} \mathrm{Sr} /{ }^{86} \mathrm{Sr}_{i}$ isopleths are drawn using data from Armstrong et al. (1977), Farmer and DePaolo, 1983, Fleck and Criss (1985), Criss and Fleck (1987), Kistler and Lee (1989), Elison et al. (1990), Leeman et al. (1992), Manduca et al. (1992), 
Wooden et al. (1999), Evans et al. (2002), Fleck and Criss (2007), Unruh et al. (2008), and Gasching et al. (2011). The 0.706 isopleth is dotted where unknown, and question marks indicate where the 0.704 isopleth is poorly constrained due to Cenozoic volcanic cover.

Fig. 1 formatting preference: color, 1.5 columns (file named Figure 1.tif).

Fig. 2. Comparison of location of proposed Rooster Comb Caldera (this study) with two calderas mapped by previous workers (Rytuba et al., 1991). Half-darkened boxes — mining prospects; triangles — campgrounds.

Fig. 2 formatting preference: grayscale, 1 column (file named Figure2.tif).

Fig. 3. Geological map and cross section of the Rooster Comb Caldera with correlation of map units. The thick line delineates the topographic margin of the caldera, dotted where covered, and queried where extrapolated. Modified from Plumley (1986), Vercoutere et al. (1987), Vander Meulen et al. (1987a,b,d; 1989b), Ferns (1988), MacLeod (1990), Ferns and Cummings (1992), and Ferns et al. (1993a,b) based on our new mapping, geochronology, and geochemical correlation of units. Boxed numbers are localities of samples discussed in text.

Fig. 3 formatting preference: color, map (file labeled Figure3a.tif) on one full page, correlation of map units (file named Figure3b.eps) on adjacent page.

Fig. 4. Tuff of Leslie Gulch intruded by a post-caldera rhyolite dike in an exposure in Leslie Gulch, deep in the intracaldera section. Note the horizontal columnar cooling joints in the dike, which is $\sim 10 \mathrm{~m}$ wide at the bottom of the photo.

Fig. 4 formatting preference: color, column (file name Figure4.tif).

Fig. 5. Photographs of intracaldera ignimbrite illustrating relationships between areas mapped as "Tuff of Spring Creek" and Tuff of Leslie Gulch. (A) High-angle "contact" between the Tuff of Leslie Gulch and the "Tuff of Spring Creek" as mapped by Vander Meulen et al. (1987d). The difference in appearance is the result of alteration, as evidenced by the gradational nature of the "contact" and the differences in alteration assemblages of samples located with stars (Fig. ). (B) Alternating green and red-to-tan alteration zones in the intracaldera ignimbrite in 
Leslie Gulch that correspond to areas affected by zeolite alteration and by quartz + albite alteration, respectively.

Fig. 5 formatting preference: color, 1 column each, adjacent (file names Figure5a.tif, Figure5b.tif).

Fig. 6. Background-corrected x-ray diffraction spectra of whole-rock samples of ignimbrite previously mapped as "Tuff of Spring Creek", Tuff of Leslie Gulch, and ignimbrite from a zone intermediate in appearance. Sample localities shown in Fig. 5a are taken from both sides of a previously mapped "contact" between the intracaldera Tuff of Leslie Gulch and "Tuff of Spring Creek". "Tuff of Spring Creek" (TB-419A) is nearly completely zeolitized to clinoptilolite. There is also a small amount of a phyllosilicate that we infer to be smectite. Peaks for minor amounts of sanidine (primary phenocryst) and mordenite are not resolvable at this scale due to the intensity of the clinoptilolite peaks. The main body of the Tuff of Leslie Gulch (TB-421A) has peaks for primary sanidine and alteration products albite and quartz, but none for zeolites. The intermediate zone (TB-420) has peaks for primary sanidine, heulandite, minor quartz, and analcime, though the peaks for analcime are not visible at this scale. Analyses performed on a PANalytical X'Pert PRO x-ray diffractometer at Stanford University using CuKa radiation at 45 $\mathrm{kV}$ and $40 \mathrm{~mA}$.

Fig. 6 formatting preference: color, 1.5 columns (file name Figure6.eps).

Fig. 7. Backscatter SEM photomicrograph of ignimbrite mapped as "Tuff of Spring Creek". Clinoptilolite nearly completely replaces ash, and forms euhedral crystals in void space.

Fig. 7 formatting preference: grayscale, 1 column (file name Figure7.tif).

Fig. 8. Trace-element variation diagrams comparing samples of ignimbrite mapped as "Tuff of Spring Creek" and Tuff of Leslie Gulch of the Rooster Comb Caldera with other MidMiocene ignimbrites associated with flood basalt volcanism. We interpret the trends defined by outflow Tuff of Leslie Gulch (black lines) to best represent the range of compositional zoning in the ignimbrite. The fields for the more altered intracaldera "Tuff of Spring Creek" and Tuff of Leslie Gulch overlap. The tuff of the Honeycombs plots along an extension of the outflow differentiation trend, suggesting that it could represent an evolved end member of the Tuff of 
Leslie Gulch. Ignimbrites of LOVF, including the Dinner Creek Tuff, have distinctively high Ba concentrations compared to the Mid-Miocene peralkaline ignimbrites of similar degree of evolution $\left(<0.35 \mathrm{wt} \% \mathrm{TiO}_{2}\right)$ at High Rock Caldera Complex (SMT = Soldier Meadow Tuff; ICT $=$ Idaho Canyon Tuff) and McDermitt Volcanic Field (OCT = Tuff of Oregon Canyon; LRT = Tuff of Long Ridge/McDermitt Tuff). Data sources: Brooks and O'Brien (1992), Ferns and O'Brien (1992), Lees (1994), Binger (1997), Evans and Binger (1998a;b), Johnson et al. (1998), Evans and Binger (1999a;b), Camp et al. (2003), Nash and Perkins (2012), Ferns and McClaughry (2013), Coble and Mahood, in press, this study (see Appendix A for analyses and description of analytical technique).

Fig. 8 formatting preference: color, 1.5 columns (file name Figure8.eps).

Fig. 9. New ${ }^{40} \mathrm{Ar} /{ }^{39} \mathrm{Ar}$ ages for rhyolites associated with the Rooster Comb Caldera. Weighted mean average age of $15.81 \pm 0.05 \mathrm{Ma}$ for five samples of Tuff of Leslie Gulch is shown as a red line with a gray box delineating its $2 \sigma$ uncertainty. Aliquots of TB- 161 were analyzed in two separate irradiations (008) and (009). See Appendix B for locations of samples.

Fig. 9 formatting preference: color, 1 column (file name Figure9.eps).

Fig. 10. Trace-element variation diagrams comparing Mid-Miocene lavas and ignimbrite associated with Rooster Comb Caldera and Late-Miocene rhyolitic lavas of the Owyhee

Front. The trend for samples of outflow Tuff of Leslie Gulch (dark orange), the field for the intracaldera ignimbrite (light orange, outlined), and the field for the tuff at the Honeycombs (yellow green) are shown for comparison. The $\sim 17$ Ma hornblende- and biotite-bearing Birch Creek low-silica rhyolite appears to be unrelated to the Rooster Comb magmatic system. The rhyolite lavas of McCain Creek (Ferns et al., 1993b; shown as Tlof west of Mahogany Mountain on Fig. 3) and Round Mountain and the Littlefield Rhyolite are similar to the younger 11.6 Ma Jump Creek Rhyolite. $\mathrm{L}=$ lithic of rhyolite lava with chemical composition of McIntyre Ridge rhyolite within the Tuff of Leslie Gulch; S=rhyolite lava of 15.61 Ma Smith Butte. Data sources: MacLeod (1990), Zimmerman (1991), and Bonnichsen et al. (2004), this study (see Appendix A).

Fig. 10 formatting preference: color, 1.5 columns (file name Figure10.eps). 
Fig. 11. View north along Succor Creek showing a steep depositional contact between tan outflow Tuff of Leslie Gulch and eroded, white, tuffaceous sediment of the lower part of the Sucker Creek Formation. In the middle ground, an intermediate lava flow is intercalated with the Sucker Creek Formation. The paleovalley was incised within the sediment above this lava and subsequently filled by the outflow sheet.

Fig. 11 formatting preference: color, 1.5 columns (file name Figure11.tif).

Fig. 12. Agate-filled lithophysae in the thick basal vitrophyre of the McIntyre Ridge rhyolite lava. Commonly referred to as "thundereggs," they are the state rock of Oregon, and are collected by rockhounds.

Fig. 12 formatting preference: color, 1 column (file name Figure12.eps).

Fig. 13. Age versus latitudinal extent of rhyolitic products associated with the McDermitt, High Rock, and Lake Owyhee volcanic fields compared to that of the four most voluminous members of the Columbia River Basalt Group. Circles $=$ new ${ }^{40} \mathrm{Ar} /{ }^{39} \mathrm{Ar}$ ages on rhyolitic lavas of the Rooster Comb Caldera; diamond = weighted mean age of the Tuff of Leslie Gulch. Data for silicic centers are from Ferns and McClaughry (2013), Benson and Mahood (2015), Coble and Mahood (in press). Extents of lavas and dikes of the Columbia River Basalt Group are from Reidel et al. (2013); ages are based on Jarboe et al., 2008, 2010; Barry et al., 2013; Baksi, 2013; this study.

Fig. 13 formatting preference: color, 1 column (file name Figure13.eps). 
Table 1. Representative whole-rock analyses of the Tuff of Leslie Gulch

\begin{tabular}{|c|c|c|c|c|}
\hline Unit type & outflow & intracaldera & intracaldera & intracaldera \\
\hline Alteration & & $a b+q t z$ & clinoptilolite & heul + mord \\
\hline Latitude & 43.5499 & 43.3178 & 43.3188 & 43.2856 \\
\hline Longitude & -117.1021 & -117.2122 & -117.3170 & -117.2595 \\
\hline Sample \# & TB-109 & TB-171 & TB-161 & TB-179 \\
\hline $\operatorname{Age}(\mathrm{Ma} \pm 2 \sigma)$ & $15.84 \pm 0.05$ & not dated & $15.81 \pm 0.03$ & $15.83 \pm 0.04$ \\
\hline \multicolumn{5}{|c|}{ Normalized Major Elements (wt \%) } \\
\hline $\mathrm{SiO}_{2}$ & 75.85 & 74.89 & 72.70 & 76.54 \\
\hline $\mathrm{TiO}_{2}$ & 0.27 & 0.26 & 0.32 & 0.28 \\
\hline $\mathrm{Al}_{2} \mathrm{O}_{3}$ & 12.31 & 12.30 & 13.29 & 12.39 \\
\hline $\mathrm{FeO}^{*}$ & 1.96 & 3.19 & 4.43 & 1.89 \\
\hline $\mathrm{MnO}$ & 0.02 & 0.10 & 0.02 & 0.01 \\
\hline $\mathrm{MgO}$ & 0.04 & 0.07 & 0.02 & 0.18 \\
\hline $\mathrm{CaO}$ & 0.10 & 0.53 & 1.85 & 1.60 \\
\hline $\mathrm{Na}_{2} \mathrm{O}$ & 4.13 & 3.31 & 4.41 & 1.91 \\
\hline $\mathrm{K}_{2} \mathrm{O}$ & 4.92 & 4.93 & 2.50 & 4.82 \\
\hline $\mathrm{P}_{2} \mathrm{O}_{5}$ & 0.04 & 0.03 & 0.03 & 0.03 \\
\hline T.E. & $\underline{0.35}$ & $\underline{0.40}$ & $\underline{0.42}$ & $\underline{0.36}$ \\
\hline TOTAL & 100.00 & 100.00 & 100.00 & 100.00 \\
\hline LOI & 0.84 & 1.59 & 10.68 & 3.96 \\
\hline \multicolumn{5}{|c|}{ Normalized Trace Element Abundances (ppm) } \\
\hline $\mathrm{Rb}$ & 142 & 151 & 122 & 106 \\
\hline $\mathrm{Sr}$ & 20 & 32 & 40 & 38 \\
\hline Y & 80 & 108 & 88 & 92 \\
\hline $\mathrm{Zr}$ & 774 & 726 & 903 & 715 \\
\hline V & 27 & 27 & 31 & 27 \\
\hline $\mathrm{Ni}$ & 3 & 4 & 2 & 3 \\
\hline $\mathrm{Cr}$ & 6 & 3 & 4 & 7 \\
\hline $\mathrm{Nb}$ & 52 & 42 & 51 & 45 \\
\hline $\mathrm{Ga}$ & 29 & 30 & 32 & 27 \\
\hline $\mathrm{Cu}$ & 5 & 2 & 4 & 5 \\
\hline $\mathrm{Zn}$ & 116 & 186 & 261 & 127 \\
\hline $\mathrm{Co}$ & 2 & 3 & 8 & 1 \\
\hline $\mathrm{Ba}$ & 1299 & 1656 & 1546 & 1458 \\
\hline $\mathrm{La}$ & 72 & 83 & 90 & 78 \\
\hline $\mathrm{Ce}$ & 222 & 228 & 232 & 198 \\
\hline $\mathrm{U}$ & 3 & 3 & & 2 \\
\hline $\mathrm{Th}$ & 17 & 15 & 29 & 17 \\
\hline $\mathrm{Pb}$ & 27 & 12 & 17 & 8 \\
\hline
\end{tabular}

Analyses performed using WD-XRF at Franklin \& Marshall College. Major-element data are normalized to $100 \%$, accounting for trace elements (T.E.) and excluding loss on ignition (LOI). 
Table 2: Summary of radiometric ages on rhyolites associated with the Rooster Comb Caldera

\begin{tabular}{|c|c|c|c|}
\hline Name of unit & $\operatorname{Age}(\mathrm{Ma} \pm 2 \sigma)$ & Method & Reference \\
\hline \multicolumn{4}{|c|}{ Birch Creek low-silica rhyolite lava } \\
\hline Birch Creek low-silica rhyolite lava (TB-278A) & $16.77 \pm 1.09$ & ${ }^{40} \mathrm{Ar} /{ }^{39} \mathrm{Ar}$ & this study ${ }^{1}$ \\
\hline \multicolumn{4}{|c|}{ McIntyre Ridge rhyolite lava } \\
\hline McIntyre Ridge rhyolite lava (TB-112) & $15.91 \pm 0.27$ & ${ }^{40} \mathrm{Ar} /{ }^{39} \mathrm{Ar}$ & this study \\
\hline McIntyre Ridge rhyolite lava & $15.8 \pm 0.6$ & $\mathrm{~K}-\mathrm{Ar}$ & Ekren et al. (1984) \\
\hline \multicolumn{4}{|c|}{ Tuff of Leslie Gulch (15.81 Ma) } \\
\hline Tuff of Leslie Gulch (TB-109) & $15.84 \pm 0.05$ & ${ }^{40} \mathrm{Ar} /{ }^{39} \mathrm{Ar}$ & this study \\
\hline "Tuff of Spring Creek" (TB-161, irr. 008) & $15.83 \pm 0.04$ & ${ }^{40} \mathrm{Ar} /{ }^{39} \mathrm{Ar}$ & this study \\
\hline "Tuff of Spring Creek" (TB-161, irr. 009) & $15.75 \pm 0.05$ & ${ }^{40} \mathrm{Ar} /{ }^{39} \mathrm{Ar}$ & this study \\
\hline "Tuff of Spring Creek" (TB-179) & $15.83 \pm 0.27$ & ${ }^{40} \mathrm{Ar} /{ }^{39} \mathrm{Ar}$ & this study \\
\hline “Tuff of Spring Creek" (TB-304A) & $15.87 \pm 0.37$ & ${ }^{40} \mathrm{Ar} /{ }^{39} \mathrm{Ar}$ & this study \\
\hline Tuff of Leslie Gulch & $15.5 \pm 0.5$ & $\mathrm{~K}-\mathrm{Ar}$ & Vander Meulen et al. (1987d) \\
\hline "Tuff of Spring Creek" & $15.4 \pm 0.2^{2}$ & ${ }^{40} \mathrm{Ar} /{ }^{39} \mathrm{Ar}$ & Hooper et al. (2002) \\
\hline \multicolumn{4}{|c|}{ Intracaldera postcaldera rhyolite lavas and intrusions $(\sim 15.8-15.6 \mathrm{Ma})$} \\
\hline Three Fingers Rock rhyolite lava (TB-196) & $15.72 \pm 0.06$ & ${ }^{40} \mathrm{Ar} /{ }^{39} \mathrm{Ar}$ & this study \\
\hline Perlitic intrusion (TB-185) & $15.87 \pm 0.28$ & ${ }^{40} \mathrm{Ar} /{ }^{39} \mathrm{Ar}$ & this study \\
\hline Perlitic intrusion & $14.9 \pm 0.4$ & $\mathrm{~K}-\mathrm{Ar}$ & Vander Meulen et al. (1987d) \\
\hline Smith Butte rhyolite lava (TB-193) & $15.61 \pm 0.05$ & ${ }^{40} \mathrm{Ar} /{ }^{39} \mathrm{Ar}$ & this study \\
\hline Rhyolite porphyry dike & $14.0 \pm 0.4$ & $\mathrm{~K}-\mathrm{Ar}$ & Vander Meulen et al. (1987d) \\
\hline Rhyolite porphyry lava & $14.9 \pm 0.4$ & $\mathrm{~K}-\mathrm{Ar}$ & Vander Meulen et al. (1987d) \\
\hline Rhyolite porphyry lava & $15.2 \pm 0.5$ & $\mathrm{~K}-\mathrm{Ar}$ & Vander Meulen et al. (1989b) \\
\hline \multicolumn{4}{|c|}{ Rattlesnake Den rhyolite lava (15.63 Ma) } \\
\hline Rattlesnake Den lava (TB-156) & $15.63 \pm 0.06$ & ${ }^{40} \mathrm{Ar} /{ }^{39} \mathrm{Ar}$ & this study \\
\hline \multicolumn{4}{|c|}{ Mahogany Mountain rhyolite lava (15.63 Ma) } \\
\hline Mahogany Mountain lava (TB-305) & $15.63 \pm 0.05$ & ${ }^{40} \mathrm{Ar} /{ }^{39} \mathrm{Ar}$ & this study \\
\hline Mahogany Mountain lava (Bannock Ridge flow) & $12.8 \pm 0.3^{2}$ & $\mathrm{~K}-\mathrm{Ar}$ & Vander Meulen (1989) \\
\hline
\end{tabular}

${ }^{1}$ Data from units analyzed in this study are detailed in Appendix B. ${ }^{2}$ Ages are too young based on stratigraphic relationships. 


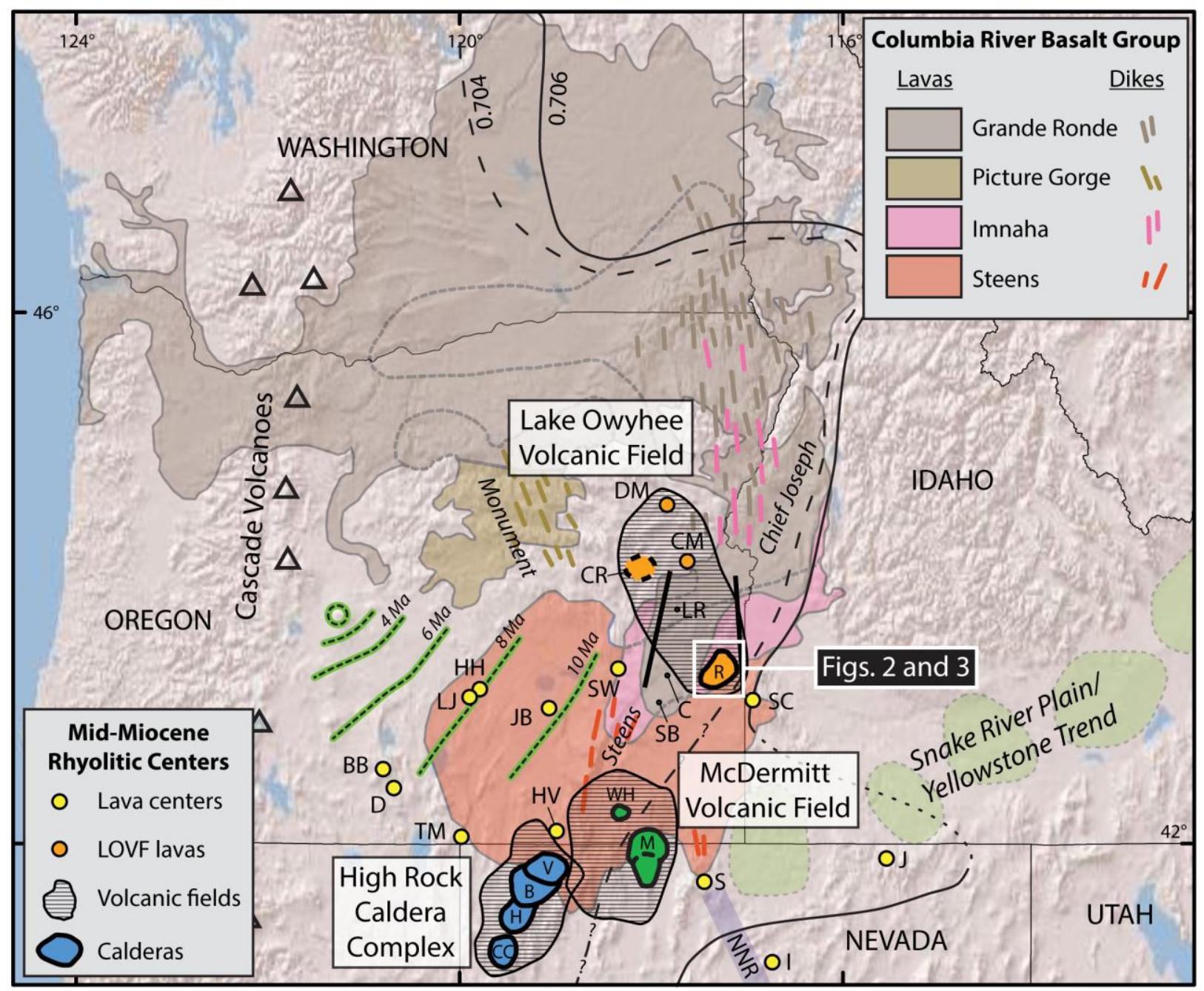




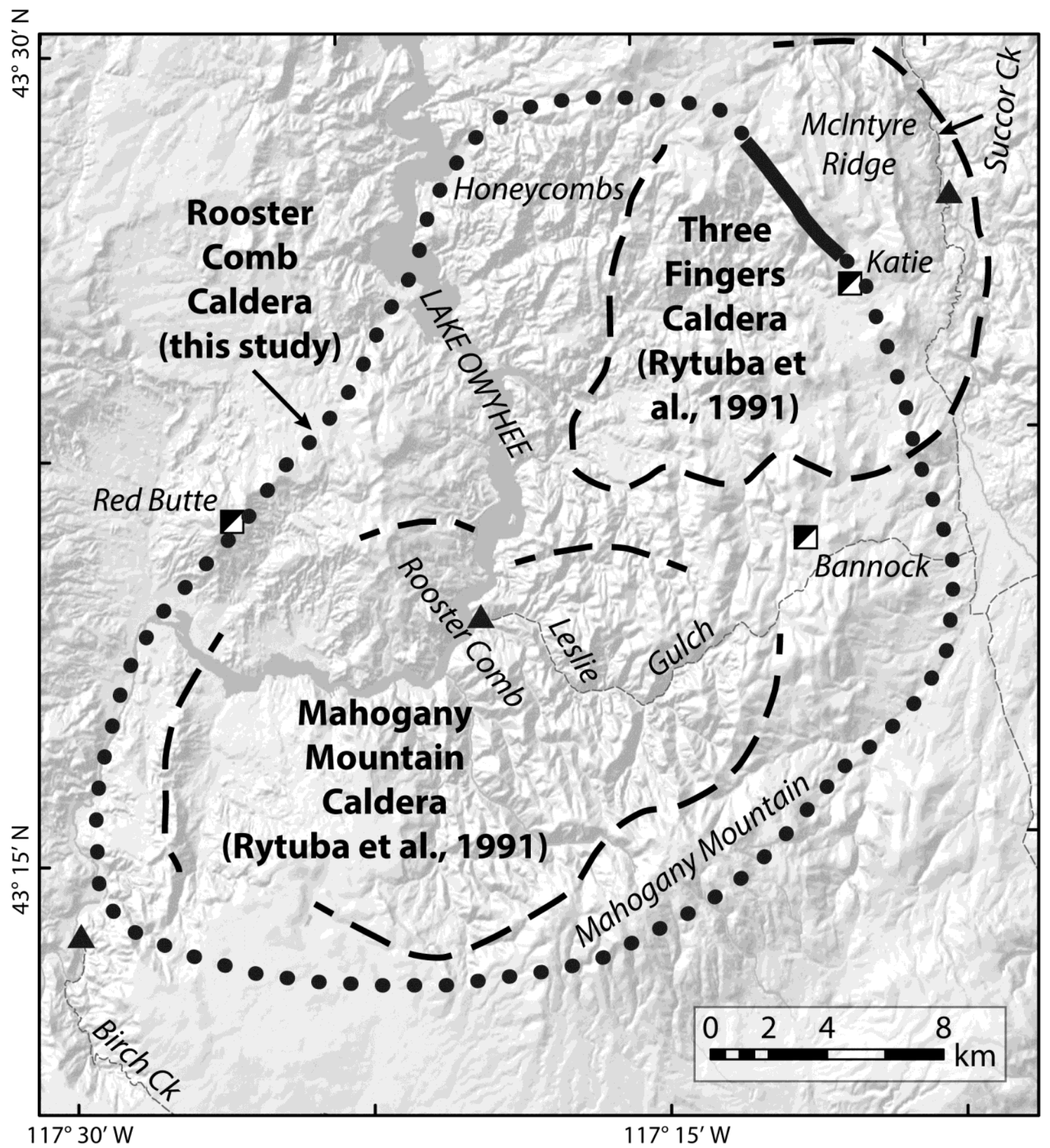




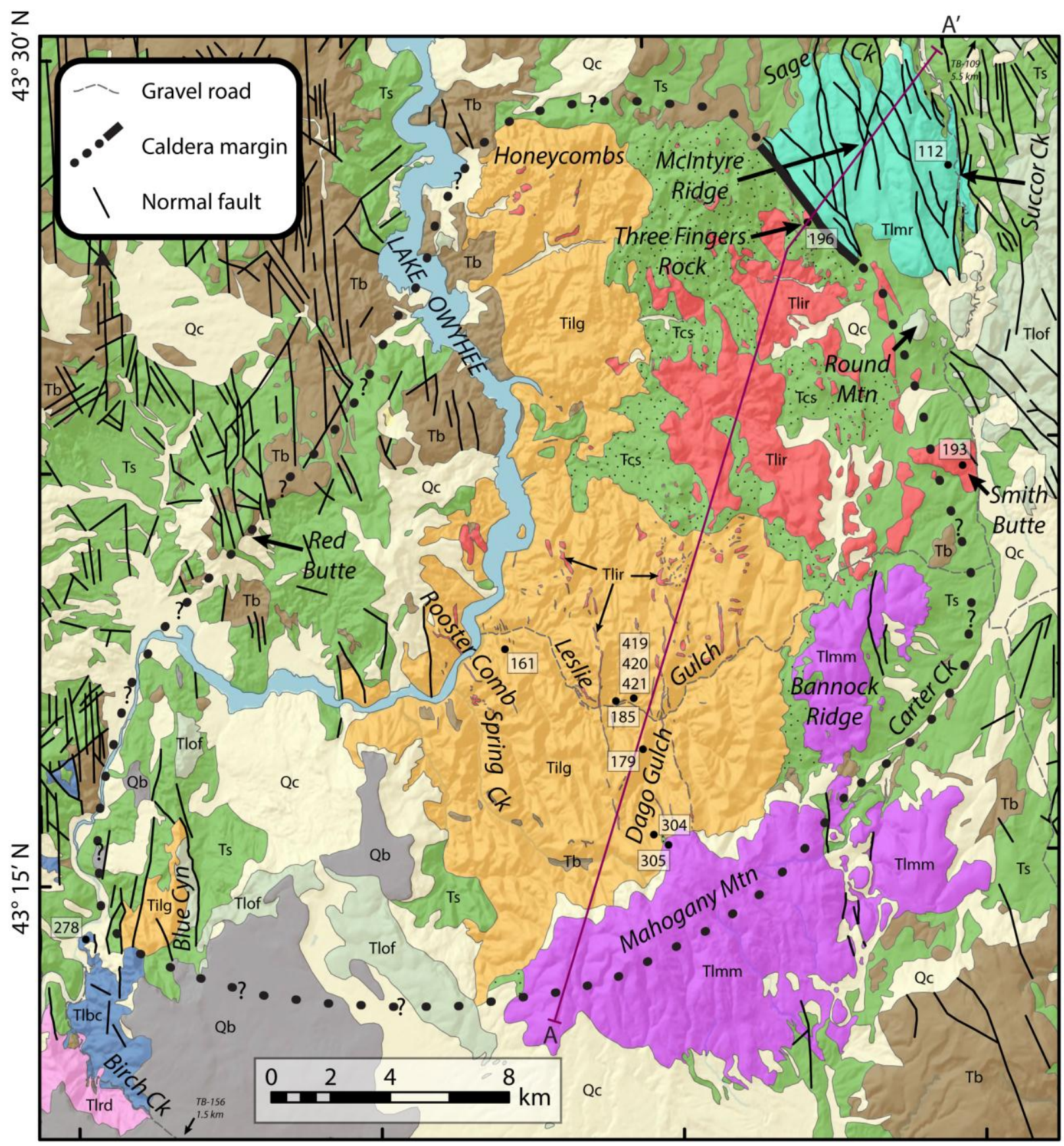

$117^{\circ} 30^{\prime} \mathrm{W}$

Mahogany

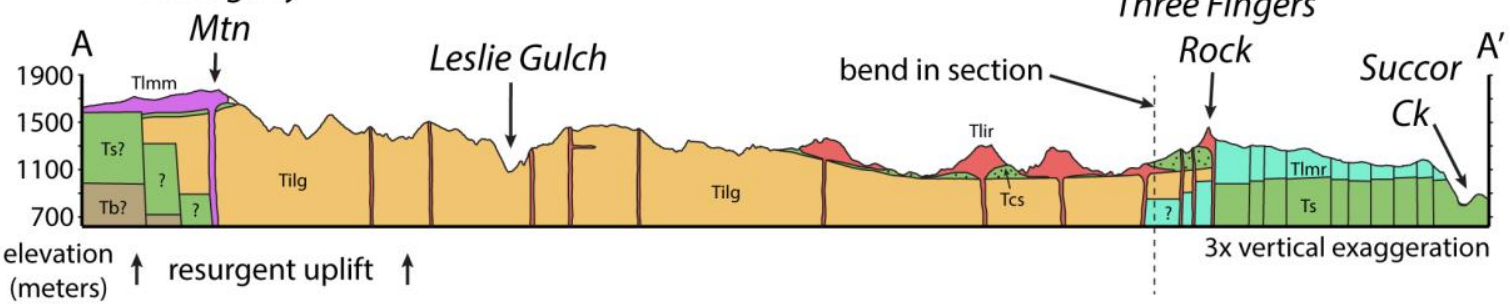




\section{CORRELATION OF MAP UNITS}

SEDIMENTARY ROCKS
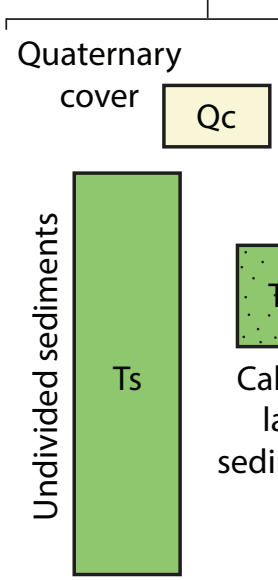

lake

sediments
CALDERA-RELATED VOLCANIC ROCKS

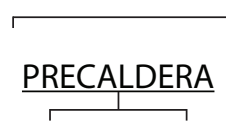

$$
\text { TImr }
$$

Mclntyre Ridge rhyolite lava

Leslie

Gulch

Tilg
OTHER VOLCANIC ROCKS

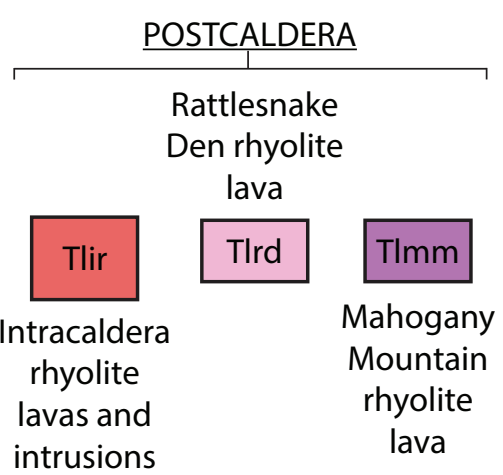

Owyhee

Front rhyolites

Tlof

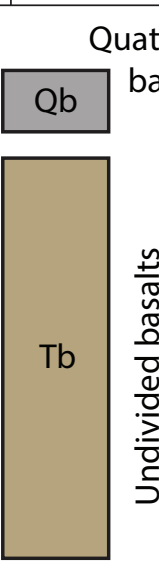




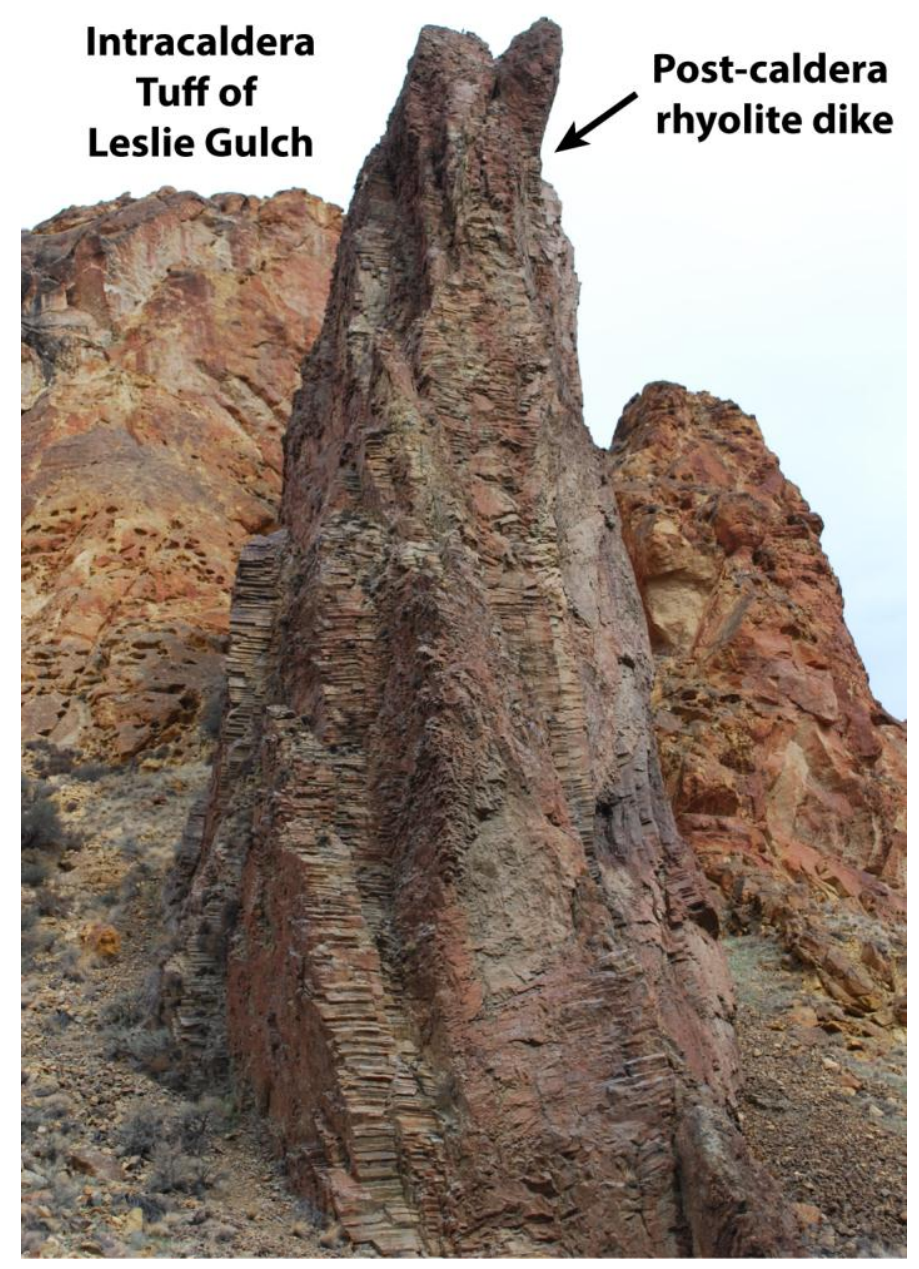




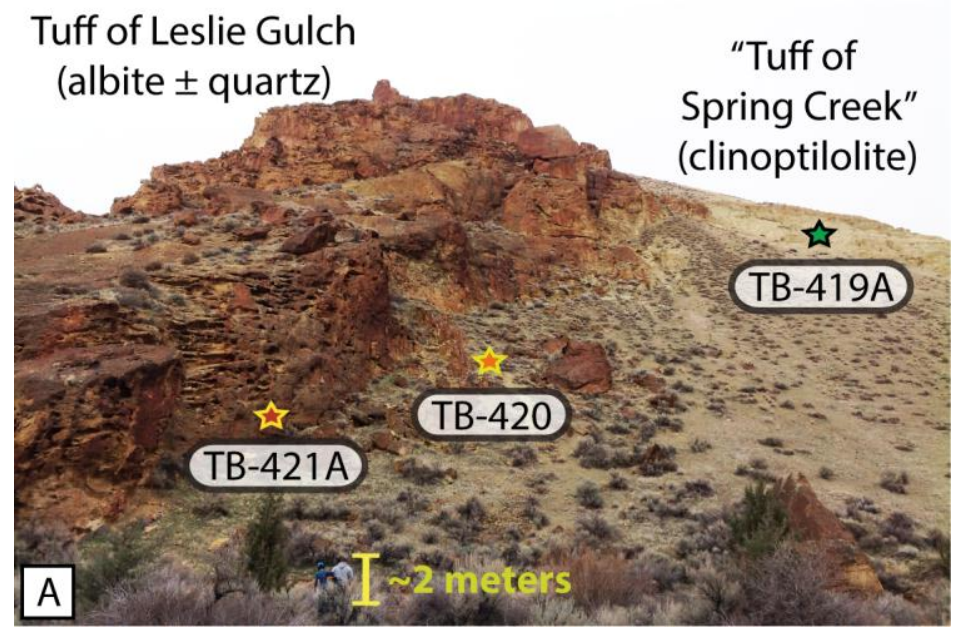




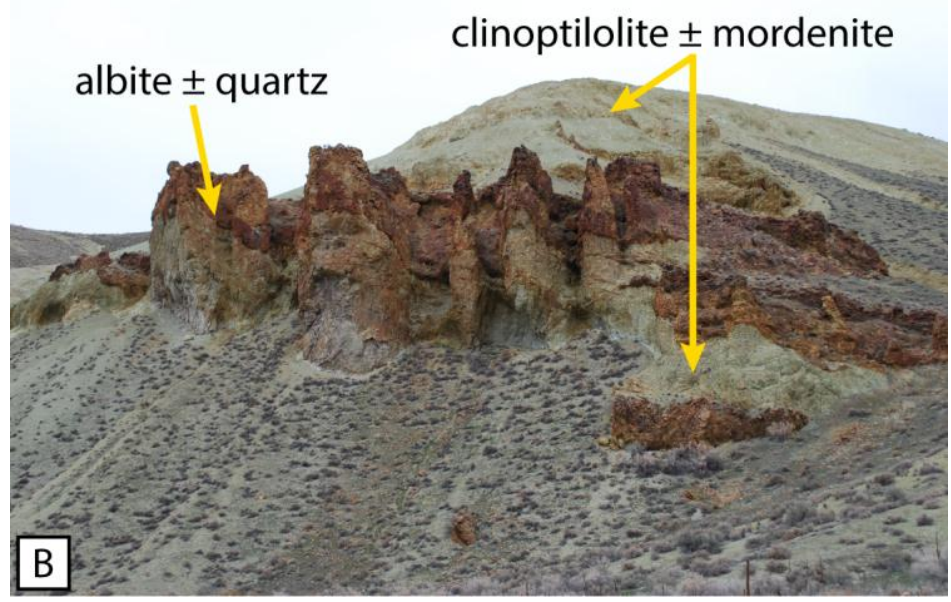




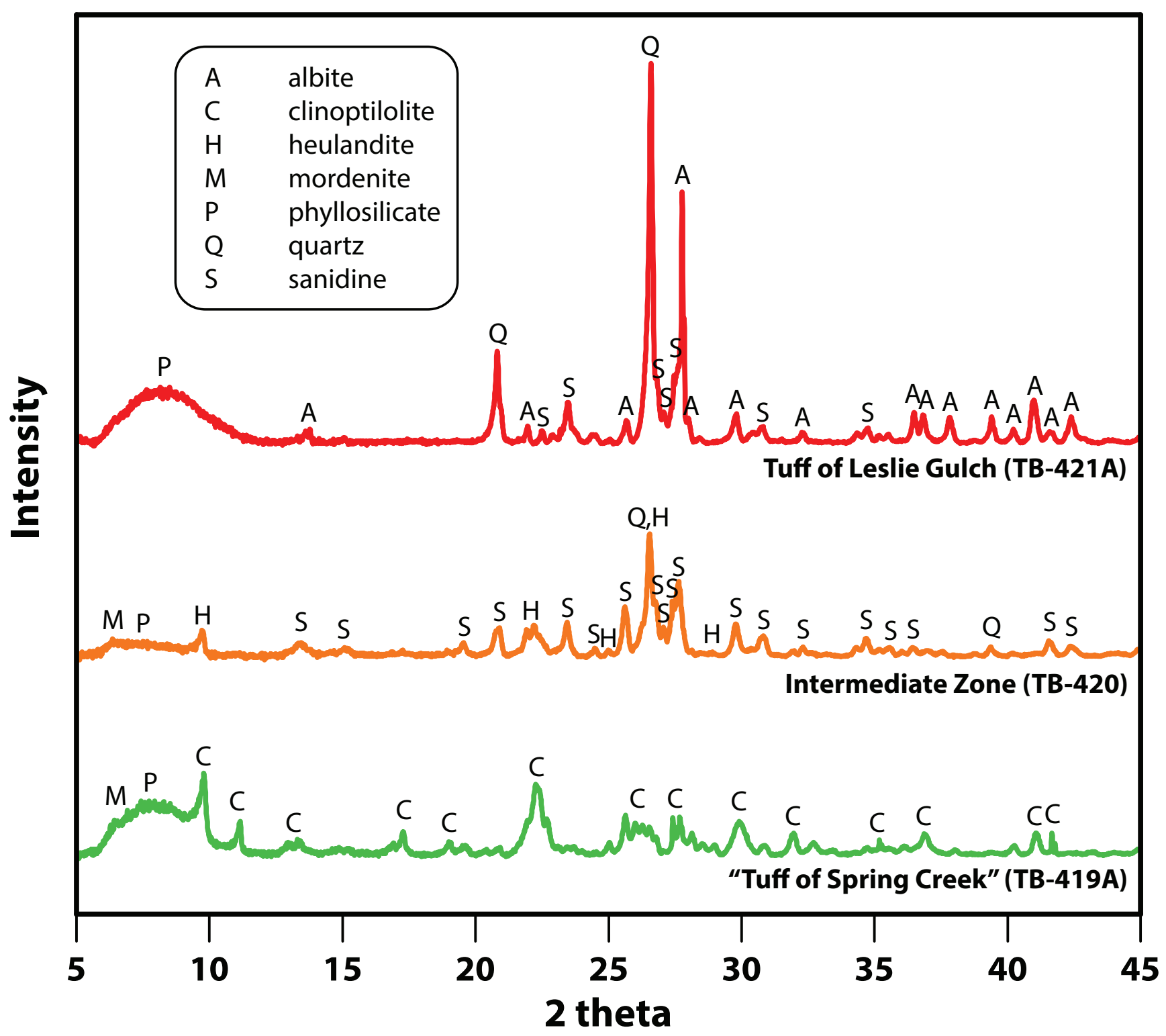




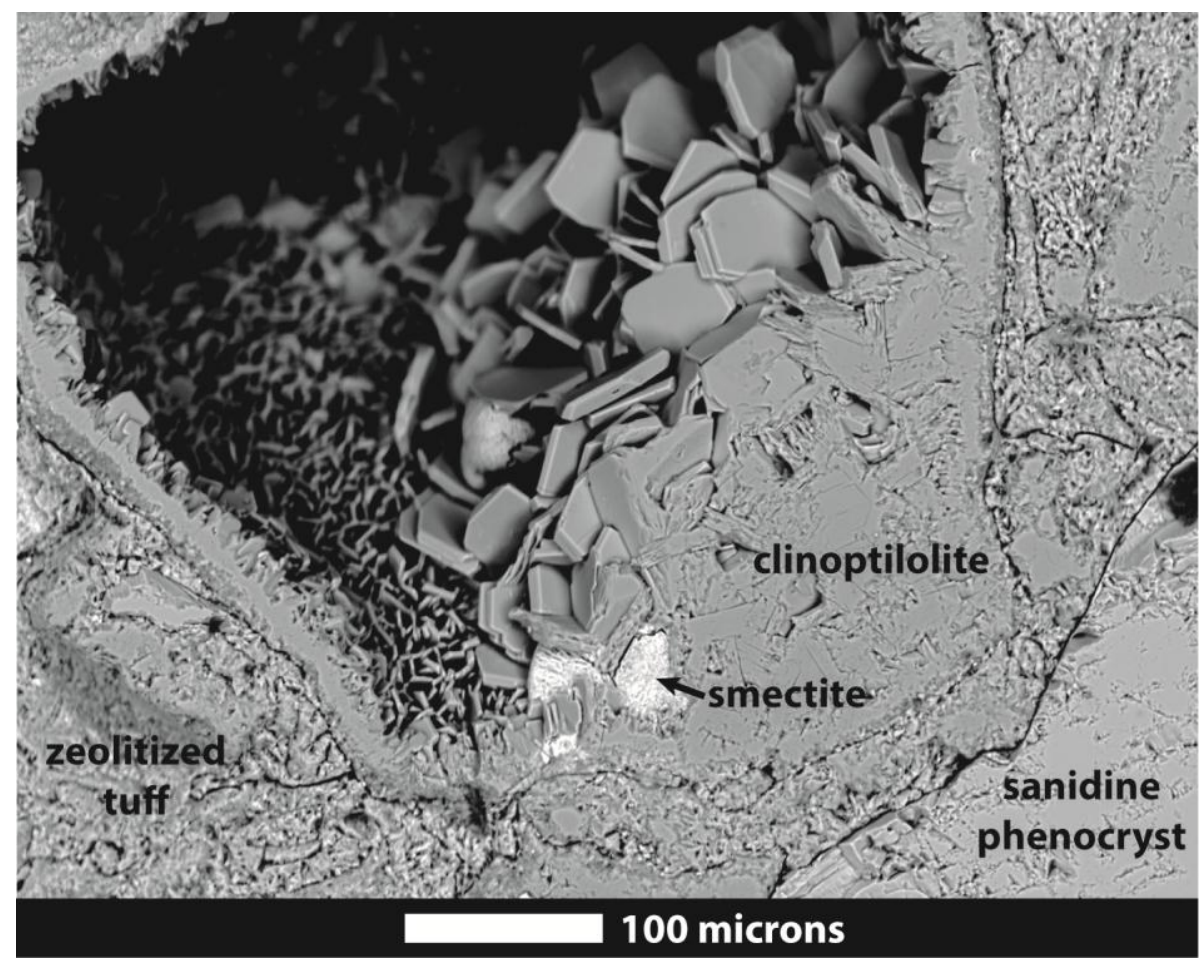



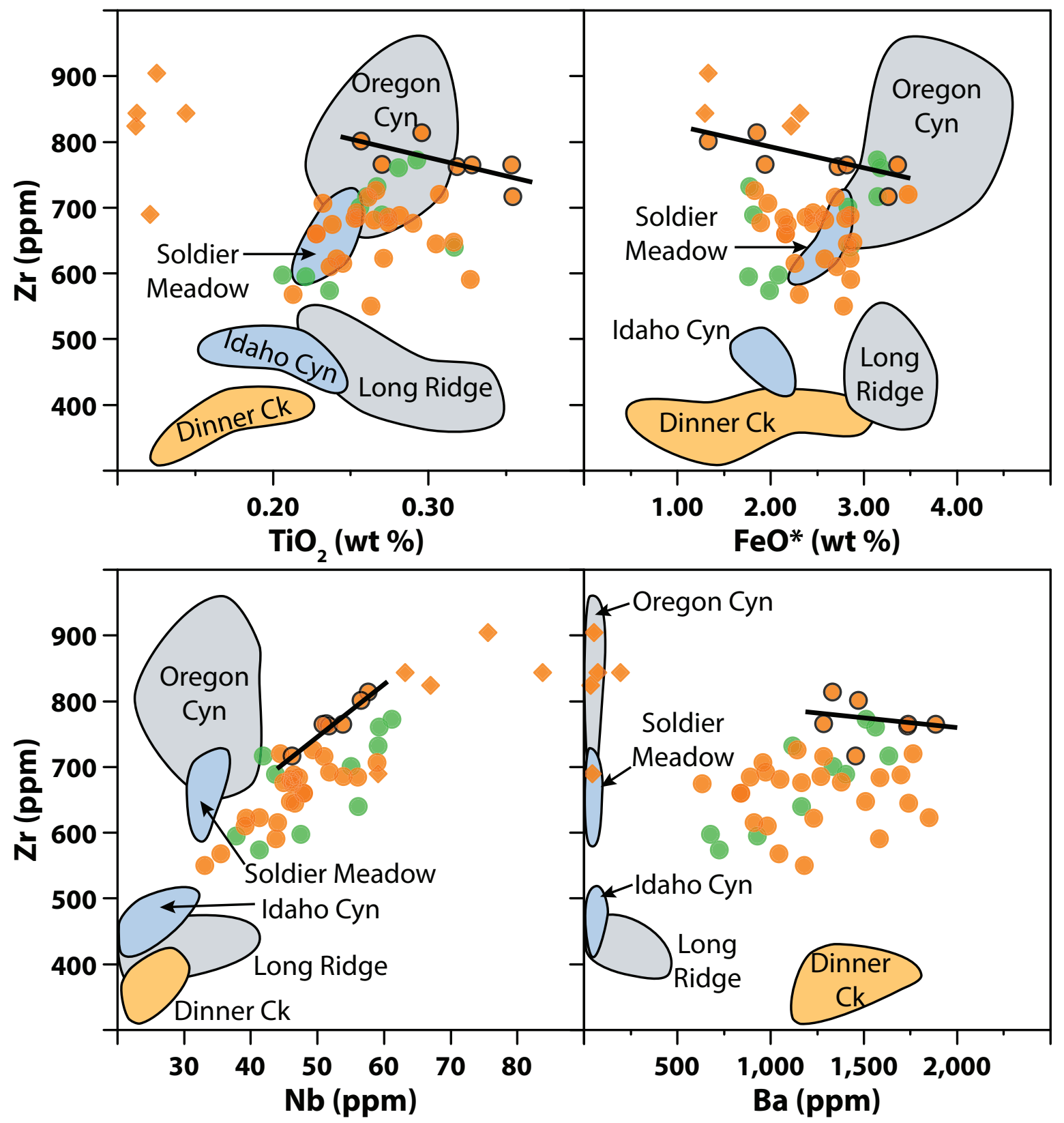

Tuff of Leslie Gulch (Intracaldera)
"Tuff of Spring Creek" (Intracaldera) 


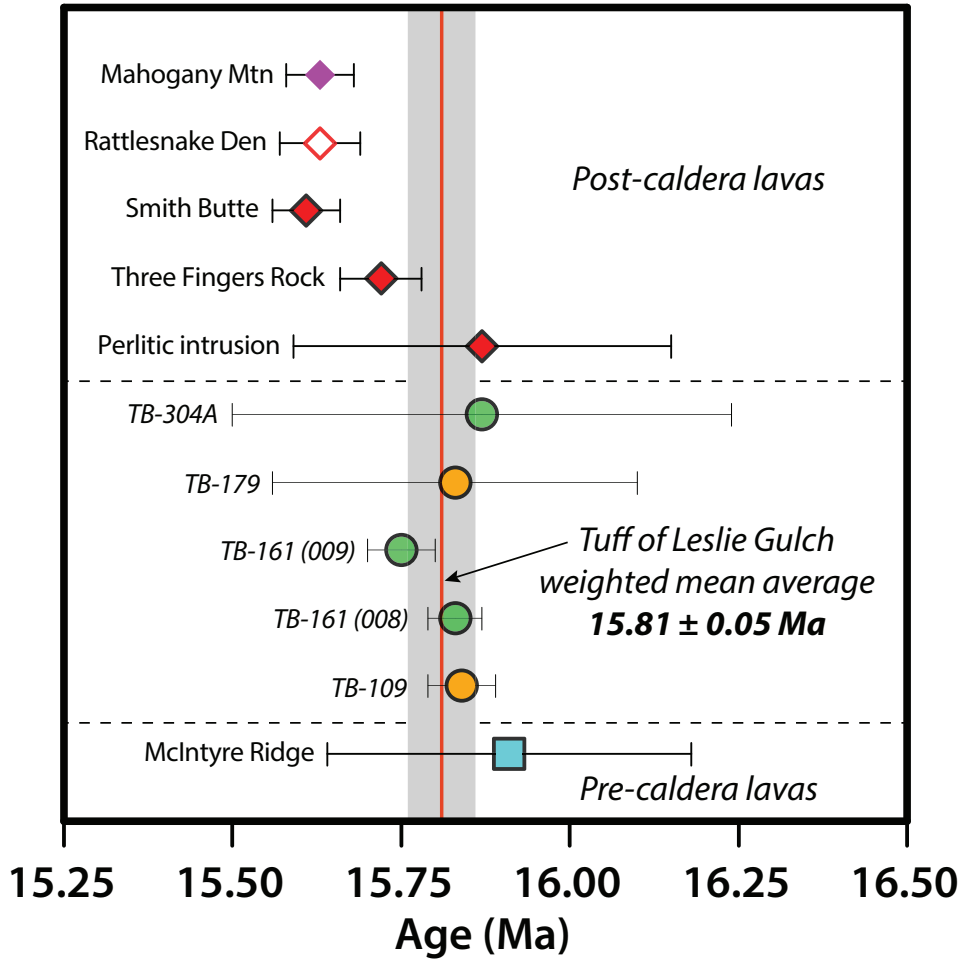




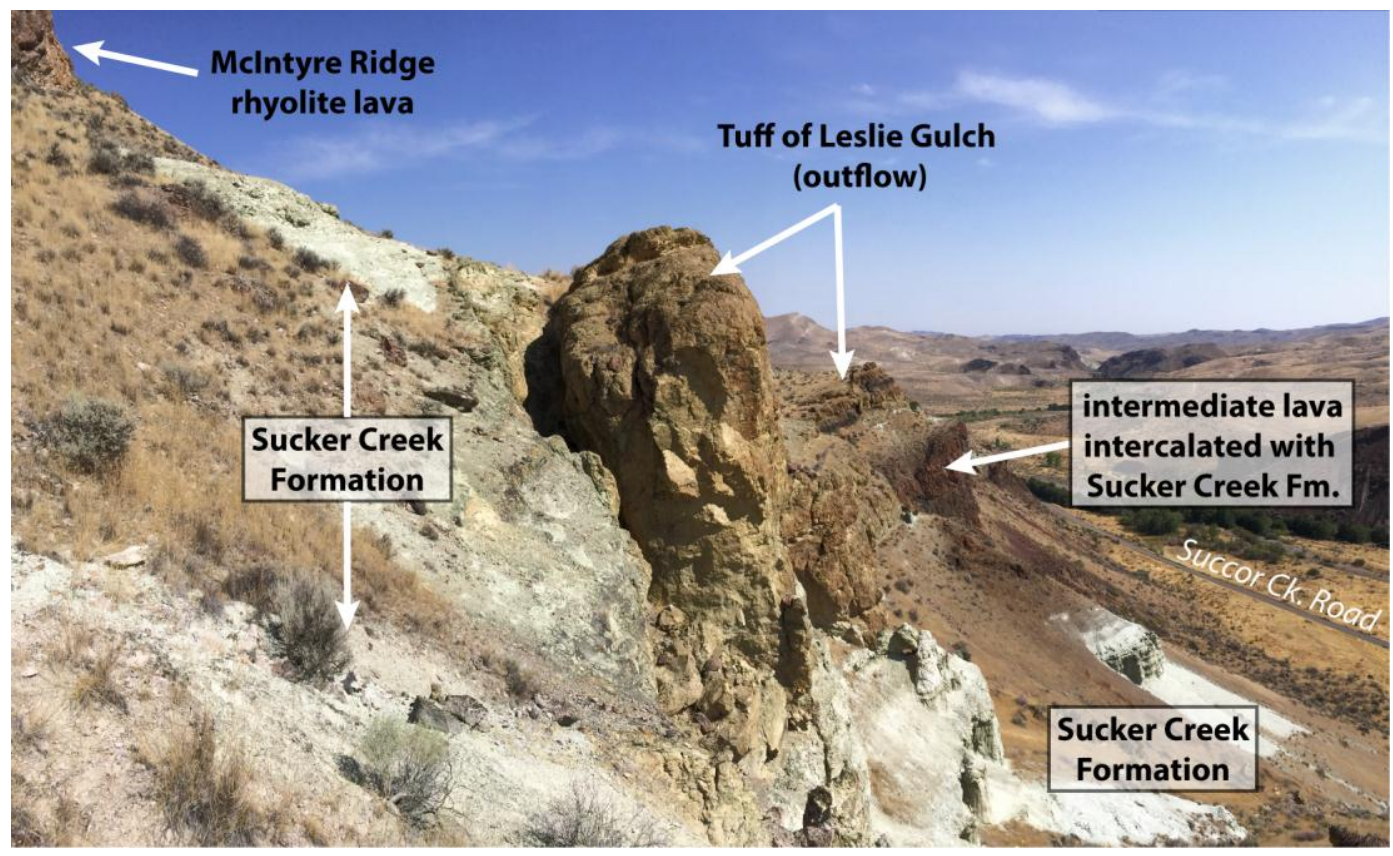




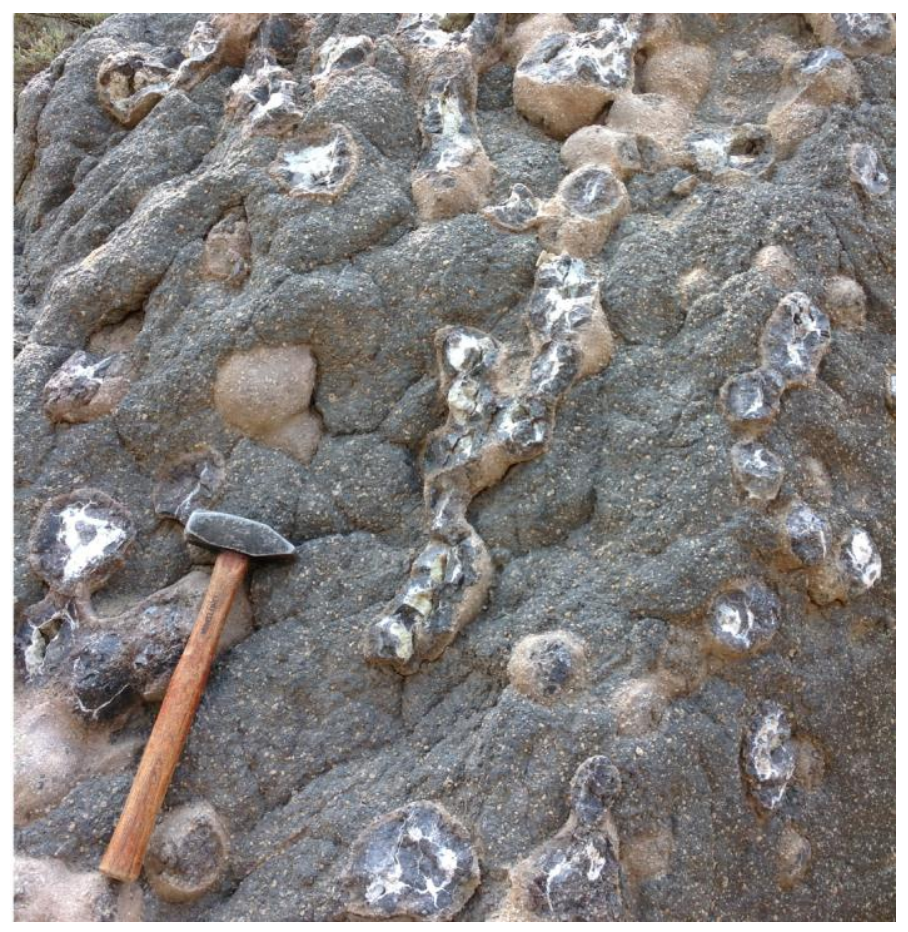




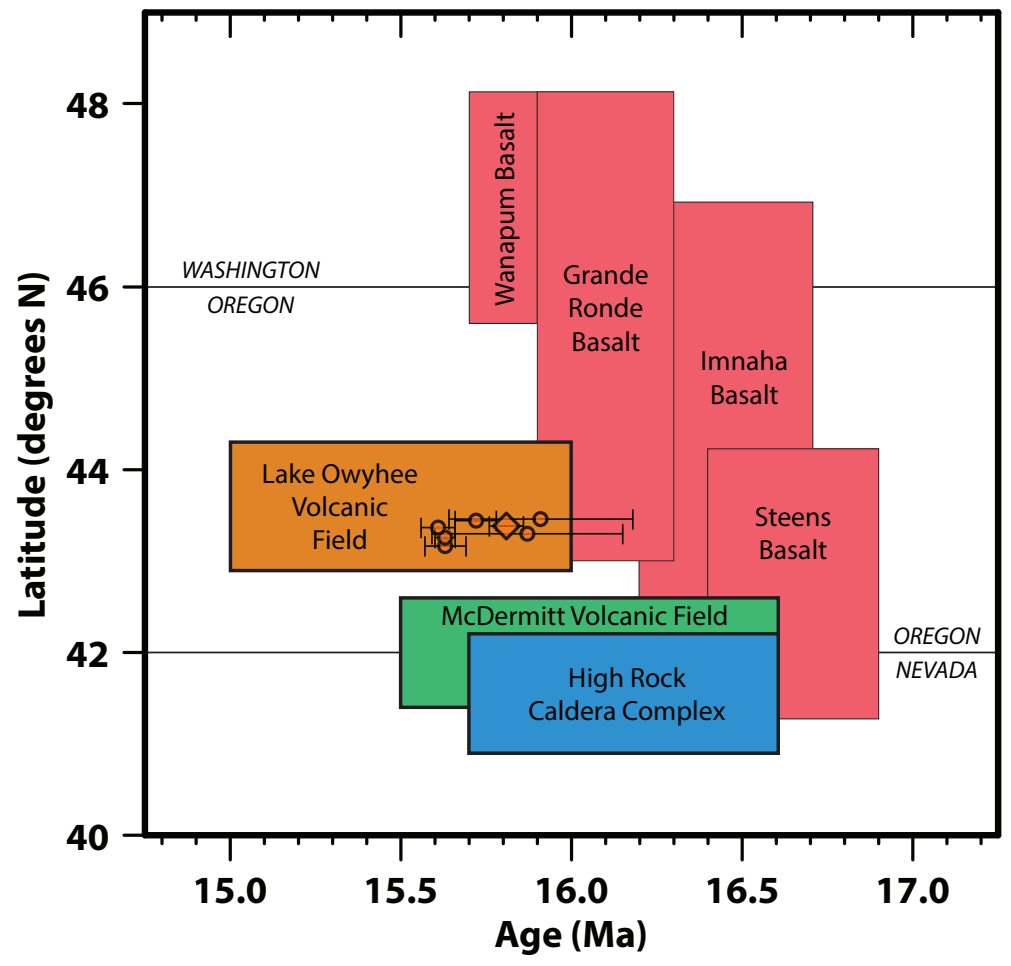

